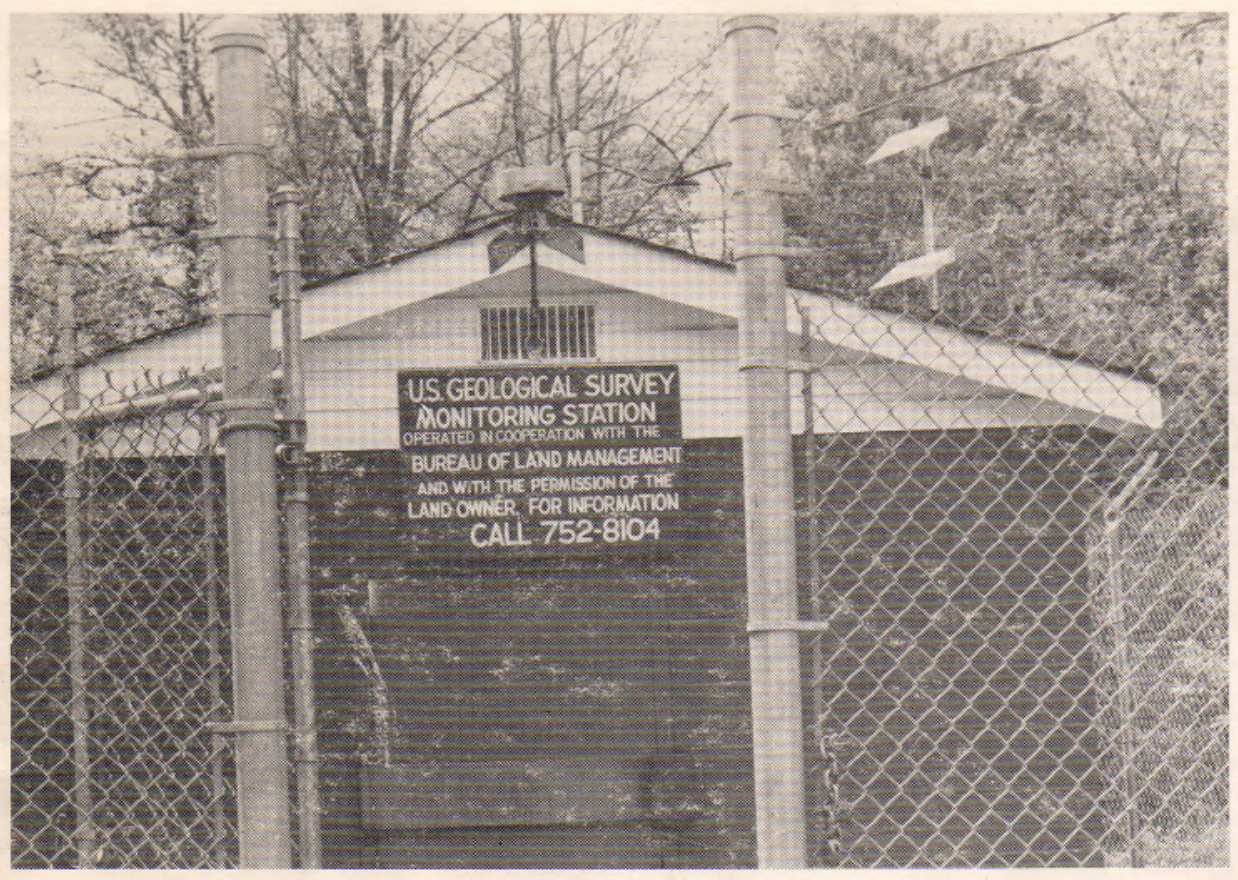

\title{
HYDROLOGY OF SELECTED BASINS IN THE WARRIOR COAL FIELD, ALABAMA-- A PROGRESS REPORT
}

U.S. GEOLOGICAL SURVEY

Water-Resources Investigations 80-22

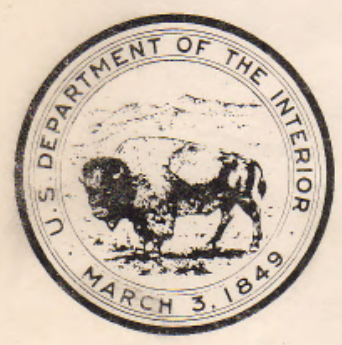

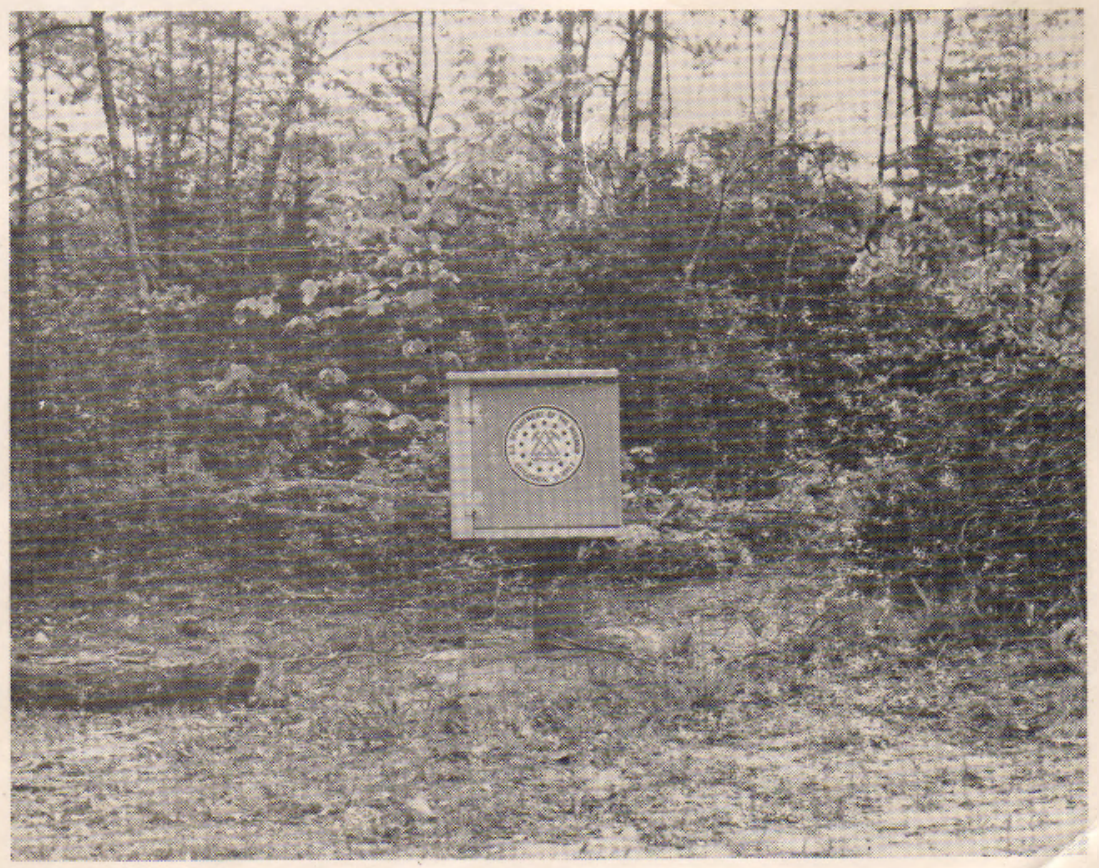




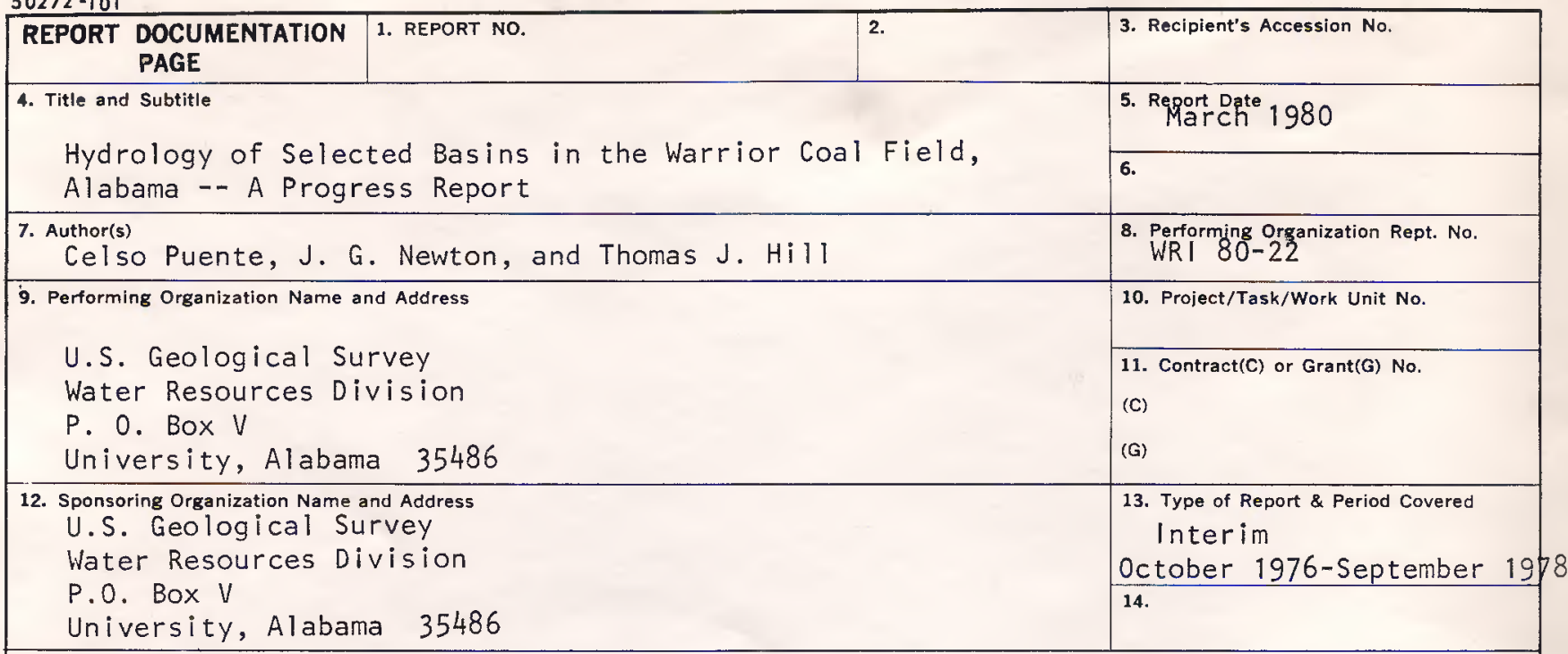

15. Supplementary Notes

16. Abstract (Limit: 200 words)

Hydrologic data are being collected in four basins in the Warrior coal field to provide baseline information to aid in determining the effect mining will have on water resources. Basins monitored are in two different geologic and hydrologic environments. Well yields from the Pottsville Formation generally range from 0 to $0.3 \mathrm{~L} / \mathrm{s}$, whereas well yields from the Coker Formation generally range from $0.3 \mathrm{~L} / \mathrm{s}$ to $6.4 \mathrm{~L} / \mathrm{s}$. Streamflow distribution reflects seasonal precipitation. Streams draining basins underlain chiefly by the Pottsville Formation frequently go dry, whereas those draining basins underlain chiefly by the Coker Formation have well sustained low flows. Water in the Pottsville Formation is slightly acidic and moderately hard to very hard. Dissolved solids concentrations ranged from 176 to $268 \mathrm{mg} / \mathrm{L}$. Water in the Coker Formation is soft, far less mineralized, and more acidic than water in the Pottsville. Surface water is generally soft, acidic, and low in dissolved solids concentrations. Water in streams draining basins underlain chiefly by the Pottsville Formation was slightly more mineralized and less acidic than water in streams draining the Coker Formation.

17. Document Analysis a. Descriptors

Coal mine wastes*, Mine drainage*, Sediment yield*, Water chemistry*, Streamflow*, Analytical techniques, Alabama.

b. Identifiers/Open-Ended Terms

Warrior coal field, Coal mining activities.

c. COSATI Field/Group

18. Availability Statement

No restriction on distribution

19. Security Class (This Report) UNCLASS IF IED

20. Security Class (This Page) UNCLASS IFIED
21. No. of Pages 62

22. Price 
HYDROLOGY OF SELECTED BASINS IN THE WARRIOR COAL FIELD, ALABAMA--

A PROGRESS REPORT

By Celso Puente, J. G. Newton, and Thomas J. Hill

U.S. GEOLOGICAL SURVEY

Water-Resources Investigations $80-22$

March 1980 
UNITED STATES DEPARTMENT OF THE INTERIOR

CECIL D. ANDRUS, Secretary GEOLOGICAL SURVEY

H. William Menard, Director

For additional information write to:

U.S. Geological Survey

1317 McFarland Blvd., East

Tuscaloosa, AL 35405 


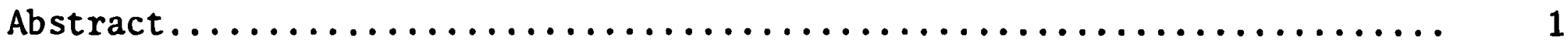

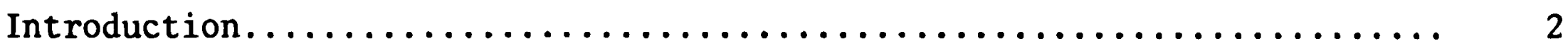

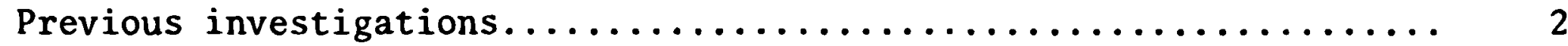

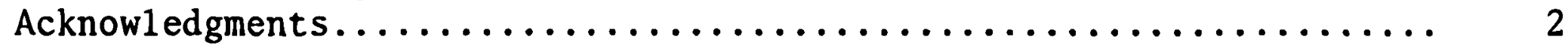

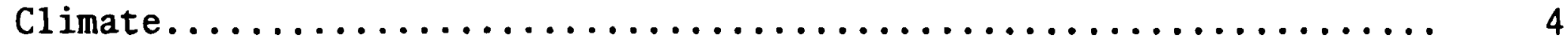

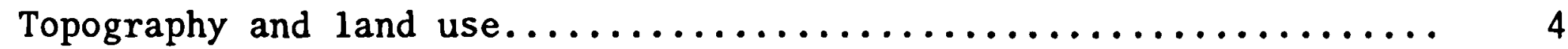

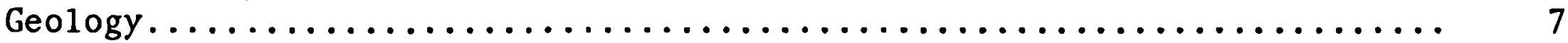

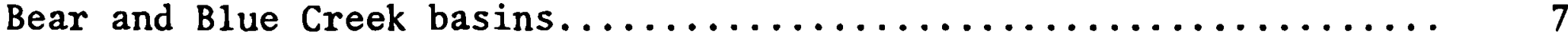

Turkey and Yellow Creek basins........................ 8

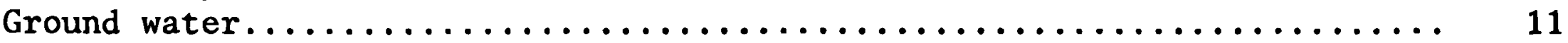

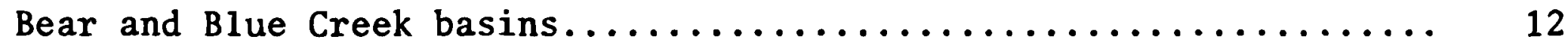

Turkey and Yellow Creek basins......................... 12

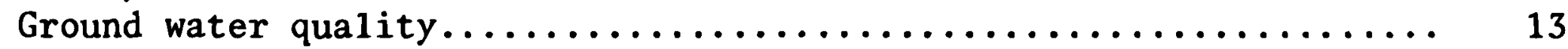

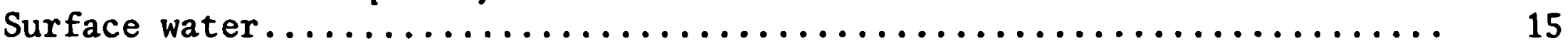

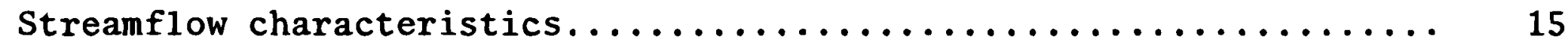

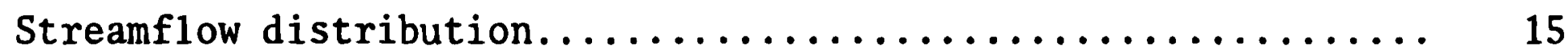

Flow duration and variability........................ 19

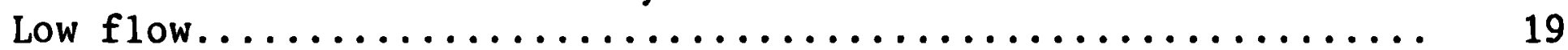

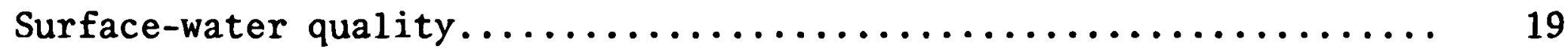

Physical properties and major constituents.............. 21

Nutrients............................... 31

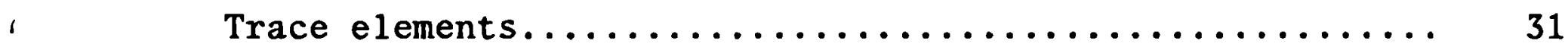

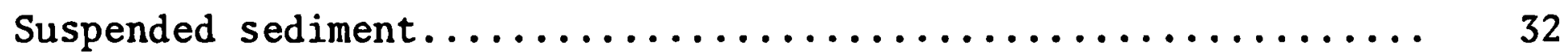

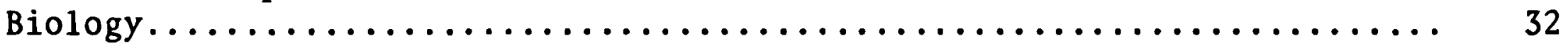

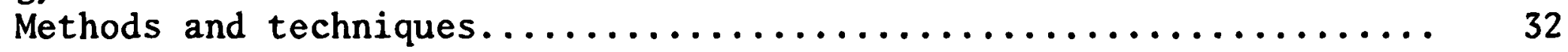

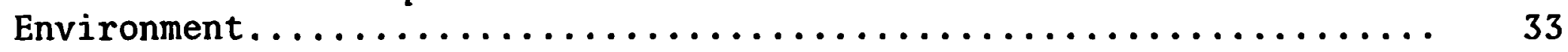

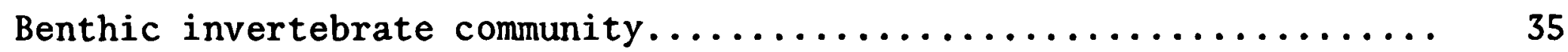

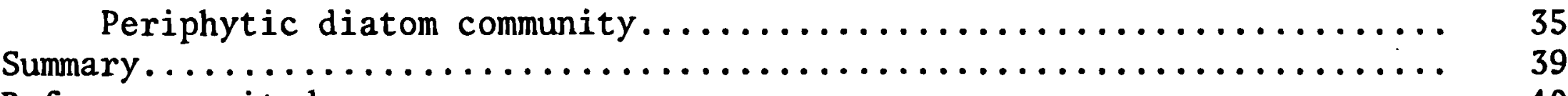

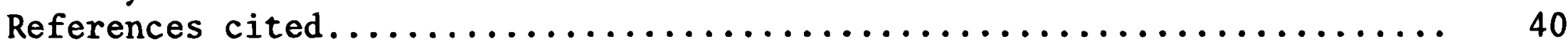

\section{ILLUSTRATIONS}

(Plates are in pocket)

P1ate 1. Geologic map of areas of study.

2. Cross section showing coal horizons, general lithologies, and structural anomalies in Bear and Blue Creek areas.

3. Cross section showing coal horizons and general lithologies in Turkey and Yellow Creek areas.

4. Map showing study areas and locations of wells and springs. 
Figure 1. Map showing areas of study and principal coal fields in

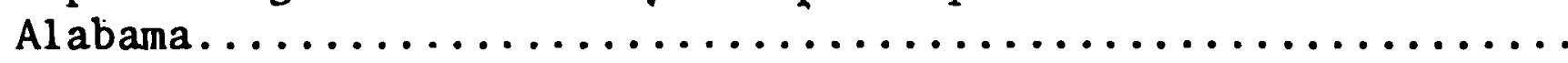

2. Graph showing monthly precipitation in and near the study area

3. Contour map showing configuration of base of Utley coal group of the Pottsville Formation in Bear and Blue Creek areas......

4. Contour map showing configuration of base of Utley coal group of the Pottsville Formation in Turkey and Yellow Creek areas..

5. Map showing locations of surface-water data collection sites..

6. Hydrographs showing daily mean discharge at site 1 (Bear Creek near Samantha), and site 3 (Blue Creek near Oakman).........

7. Hydrograph showing daily mean discharge at site 7 (Yellow

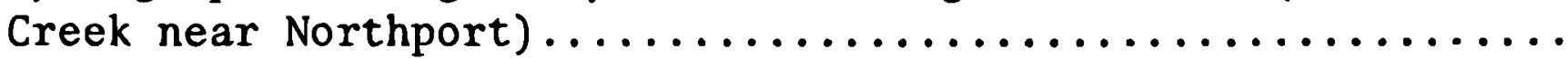

8-18. Graphs showing:

8. Flow-duration curves for sites 1 (Bear Creek near Samantha), 3 (Blue Creek near Oakman), and 7 (Yellow Creek near Northport), October 1976-September 1978.......

9. Variations in monthly mean stream discharge, specific conductance, and water temperature at site 1 (Bear Creek

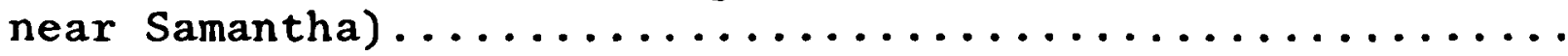

10. Variations in monthly mean stream discharge, specific conductance, and water temperature at site 7 (Yellow

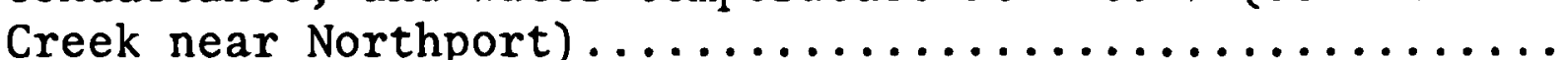

11. Chemical composition of stream discharge (Q), and relationship between suspended sediment and stream discharge at site 1 (Bear Creek near Samantha)...........

12. Chemical composition of stream discharge $(Q)$, and relationship between suspended sediment and stream discharge at site 2 (Dry Branch near Samantha) ...........

13. Chemical composition of stream discharge (Q), and relationship between suspended sediment and stream discharge at site 3 (Blue Creek near Oakman)........... 
Figures 8-18. Graphs showing--Continued

14. Chemical composition of stream discharge $(Q)$, and relationship between suspended sediment and stream discharge at site 4 (Turkey Creek near Tuscaloosa).........

15. Chemical composition of stream discharge (Q), and relationship between suspended sediment and stream discharge at site 5 (Yellow Creek above Northport).........

16. Chemical composition of stream discharge (Q), and relationship between suspended sediment and stream discharge at site 6 . (tributary to Yellow Creek near

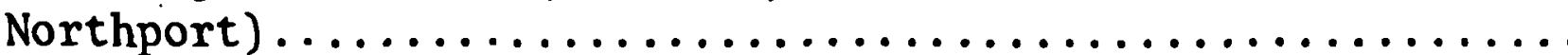

17. Chemical composition of stream discharge (Q), and relationship between suspended sediment and stream discharge at sj.te 7 (Yellow Creek near Northport).........

18. Variations of generic diversity and richness at selected

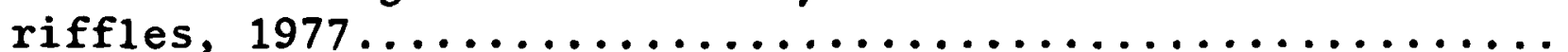

TABLES

Table 1. Land use, February $1977 \ldots \ldots \ldots \ldots \ldots \ldots \ldots \ldots \ldots \ldots \ldots \ldots$

2. Records of wells and springs in and near study areas in

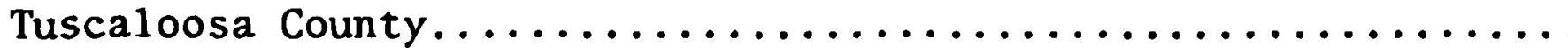

3. Records of test wells drilled in and near study areas in Tuscaloosa County.............................. 46

4. Quality of water from selected wells and springs.......... 49

5. Summary of surface water data collection network.......... 51

6. Monthly and annual mean stream discharge for sites 1,3 ,

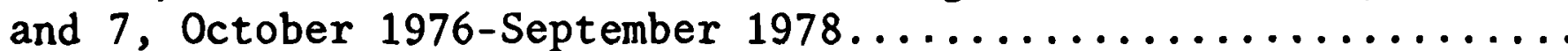

7. Mean values of selected physical and chemical constituents of rainfall in Tuscaloosa, Alabama in 1973 and $1975 . \ldots \ldots \ldots \ldots \ldots$

8-15. Summary of :

8. Selected chemical and physical characteristics of water at site 1 (Bear Creek at Samantha). 
Tables 8-15. Summary of--Continued

9. Selected chemical and physical characteristics of water at site 2 (Dry Branch near Samantha)................ 54

10. Selected chemical and physical characteristics of water at site 3 (Blue Creek near Oakman) .................. 55

11. Selected chemical and physical characteristics of water at site 4 (Turkey Creek near Tuscaloosa)................ 56

12. Selected chemical and physical characteristics of water at site 5 (Yellow Creek above Northport) ............... 57

13. Selected chemical and physical characteristics of water at site 6 (tributary to Yellow Creek near Northport)........ 58

14. Selected chemical and physical characteristics of water at site 7 (Yellow Creek near Northport)............... 59

15. Annual suspended-sediment discharge and sediment yields at site 1 (Bear Creek near Samantha) and site 7 (Yellow Creek near Northport), October 1976-September 1978........... 60

16. Percent composition of bed material in streams, July 1978..... 34

17. Actual and relative numerical abundance of benthic invertebrates collected in riffles................... 61

18. Diversity, richness, evenness, and total number of organisms for benthic invertebrate communities, May-August $1977 \ldots \ldots \ldots \ldots 36$

19. List of diatoms collected in project area.............. 62

20. Diversity, richness, evenness, and total number of organisms for periphytic diatom communities, May-August $1977 \ldots \ldots \ldots \ldots \ldots$ 
FACTORS FOR CONVERTING INTERNATIONAL SYSTEM (SI) UNITS

TO INCH-POUND UNITS

\begin{tabular}{|c|c|c|}
\hline Divide SI units & By & To obtain inch-pound units \\
\hline millimeter (mm) & 25.4 & inch (in) \\
\hline centimeter $(\mathrm{cm})$ & 2.540 & inch (in) \\
\hline meter $(\mathrm{m})$ & 0.3048 & foot $(f t)$ \\
\hline kilometer $(\mathrm{km})$ & 1.609 & mile (mi) \\
\hline square kilometer $\left(\mathrm{km}^{2}\right)$ & 2.590 & square mile $\left(\mathrm{mi}^{2}\right)$ \\
\hline meter per kilometer $(\mathrm{m} / \mathrm{km})$ & 0.1894 & foot per mile $(\mathrm{ft} / \mathrm{mi})$ \\
\hline metric ton $(t)$ & 0.9072 & ton (short, 2,000 lbs) \\
\hline metric tons per day $(t / d)$ & 0.9072 & tons per day (ton/d) \\
\hline $\begin{array}{l}\text { metric tons per square kilometer } \\
\qquad\left(\mathrm{t} / \mathrm{km}^{2}\right)\end{array}$ & 0.3503 & tons per square $\mathrm{mile}\left(\right.$ ton $\left./ \mathrm{mi}^{2}\right)$ \\
\hline liter per second $(L / s)$ & 28.32 & cubic foot per second $\left(\mathrm{ft}^{3} / \mathrm{s}\right)$ \\
\hline liter per second $(L / S)$ & 0.06309 & gallon per minute (gal/min) \\
\hline cubic meter per second $\left(\mathrm{m}^{3} / \mathrm{s}\right)$ & 0.02832 & cubic foot per second $\left(\mathrm{ft}^{3} / \mathrm{s}\right)$ \\
\hline $\begin{array}{l}\text { cubic meter per second per } \\
\text { square kilometer }\left[\left(\mathrm{m}^{3} / \mathrm{s}\right) / \mathrm{km}^{2}\right]\end{array}$ & 0.010934 & $\begin{array}{l}\text { cubic foot per second per square } \\
\text { mile }\left[\left(\mathrm{ft}^{3} / \mathrm{s}\right) / \mathrm{mi}^{2}\right]\end{array}$ \\
\hline
\end{tabular}

Temperature, ${ }^{\circ} \mathrm{C}$ (Celsius) $+17.78 \times 1.8={ }^{\circ} \mathrm{F}$ (Fahrenheit).

Vertical control in report is based on National Geodetic Vertical Datum (NGVD) of 1929. 


\section{ABSTRACT}

Hydrologic data are being collected in four basins in the Warrior coal field to provide baseline information to aid in determining the effect mining will have on water resources. Preliminary findings are based on information collected during the first 2 years (October 1976 through September 1978) of a planned 5-year study.

Basins monitored are in two different geologic and hydrologic environments. Two basins are underlain predominantly by relatively impermeable indurated rocks in the Pottsville Formation of Pennsylvanian age. The two remaining basins are underlain predominantly by unconsolidated permeable rocks in the Coker Formation of Late Cretaceous age.

Well yields from the Pottsville Formation generally range from 0 to 0.3 $\mathrm{L} / \mathrm{s}$, whereas well yields from the Coker Formation generally range from $0.3 \mathrm{~L} / \mathrm{s}$ to $6.4 \mathrm{~L} / \mathrm{s}$.

Streamflow distribution reflects seasonal precipitation. Storm runoff is. characterized by sharply concentrated flows of short duration that rapidly recede to low-flow conditions. Streams draining basins underlain chiefly by the Pottsville Formation frequently go dry, whereas those draining basins underlain chiefly by the Coker Formation have well sustained low flows.

Water in the Pottsville Formation is slightly acidic and moderately hard to very hard. Dissolved solids concentrations ranged from 176 to $268 \mathrm{mg} / \mathrm{L}$. Water in the Coker Formation is soft, far less mineralized, and more acidic than water in the Pottsville.

Surface water is generally soft, acidic, and low in dissolved solids concentrations. Water in streams draining basins underlain chiefly by the Pottsville Formation was slightly more mineralized and less acidic than water in streams draining the Coker Formation. 
Increased extraction and utilization of coal as a source of energy has become necessary to supplement dwindling oil and gas reserves. Maximum deve1opment of this source of energy will require mining of Federally owned coal reserves. In Alabama, the largest part of the reserves that may be released for mining in the foreseeable future are in the Warrior coal field in Fayette, Walker, and Tuscaloosa Counties (fig. 1). Two areas of study in north Tuscaloosa County, also shown in figure 1 , were selected because surface coal mining in the Warrior coal field occurs in two geologically and hydrologically dissimilar environments depicted by these areas.

The impact of mining Federally owned coal reserves, like any disturbance of the natural environment, can result in a variety of problems. The U.S. Bureau of Land Management has the responsibility of assessing the impact on the environment and determining actions that will minimize resulting problems. The U.S. Geological Survey, Water Resources Division, has the responsibility of collecting and providing baseline hydrologic information to the Bureau of Land Management to aid in the preparation of their environmental impact statement.

Data collection to define the hydrology within the area of study began in October 1976. The purpose of this report is to define basic hydrologic processes and to present findings for the period October 1976 through September 1978 to aid in early assessments of the impact of future mining. The final report resulting from the project is scheduled for completion in October 1981 .

\section{PREVIOUS INVESTIGATIONS}

Most previous investigations have been reconnaissance in nature and provide limited information that aids in defining baseline conditions or basic hydrologic processes in the area of study. Miller (1958); Miller and Causey (1958); Paulson and others (1962); and Wahl (1965) prepared reports describing the geology and ground-water resources in the study area and adjacent areas. Peirce $(1959,1962)$ provided information on surface-water quantity and quality. McCalley (1900) defined coal units in the Warrior coal field; Culbertson (1964) recognized and named the Utley coal group, and Shotts (1967) provided information on its distribution. Some prominent geologic structures were located on a map in Semmes (1929).

\section{ACKNOWLEDGMENTS}

Acknowledgment is made to several individuals, agencies, and companies for their contributions to this investigation. Mr. Sam Baker, National Weather Service, provided weather forecasts during climatic events. Messrs. Don Prestley and Ken Wilson, U.S. Soil Conservation Service, provided soils information and soils maps. Messrs. Thomas W. Daniel, Jr., and Charles W. Copeland, Geological Survey of Alabama, furnished information on coal beds and associated strata. Mr. Mitchell Hilton, Black Jack Mining Company, Mr. Roland Pugh, Pugh 


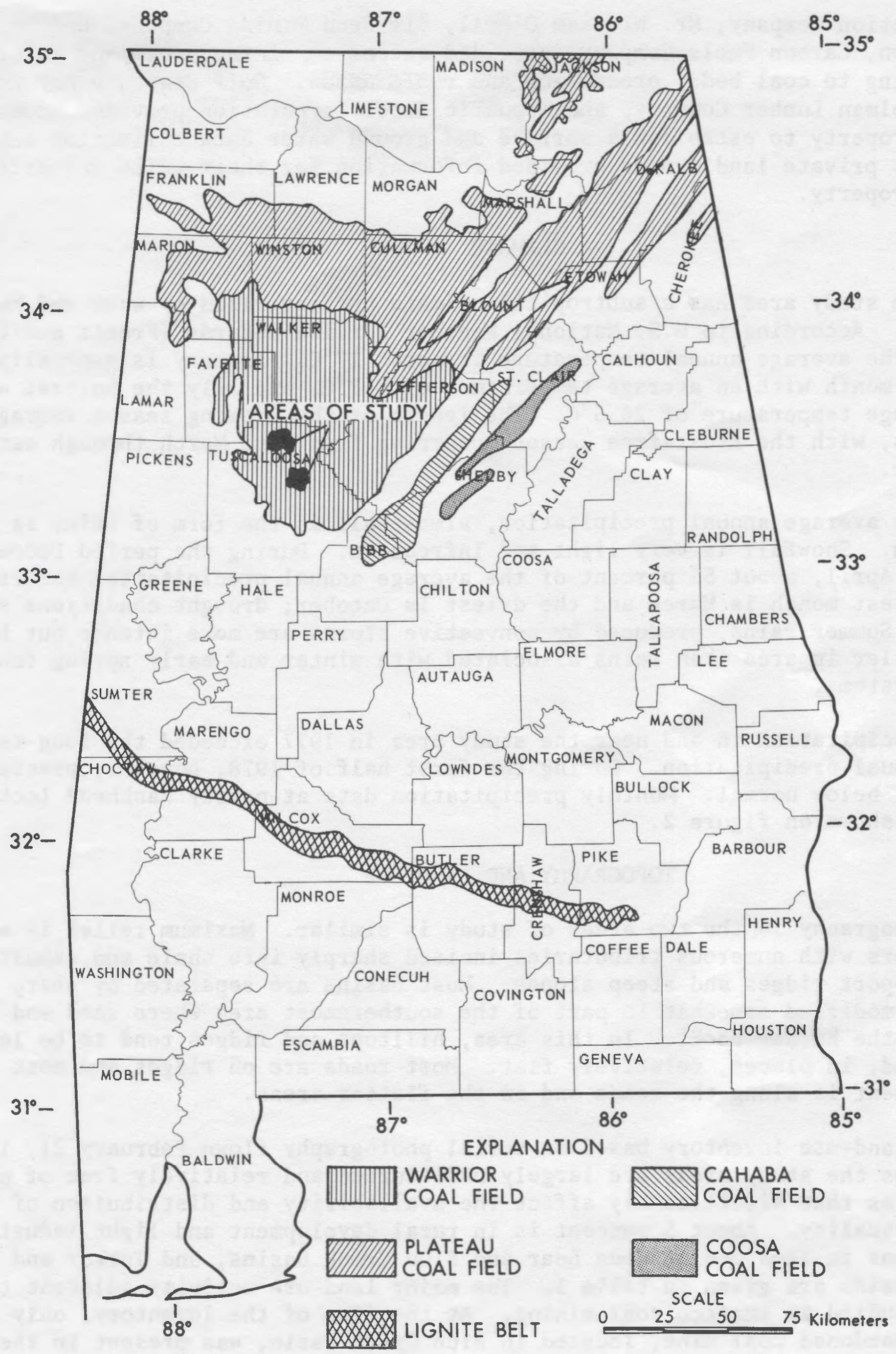

Figure 1.--Areas of study and principal coal fields in Alabama (modified from Ward and Evans, 1975). 
Construction Company, Mr. William O'Del1, Big Bend Mining Company, and Mr. Joe Stevenson, Carbon Fuels Company, provided access to mining areas and information pertaining to coal beds, production and reclamation. Gulf States Paper Corporation, Holman Lumber Company, and Republic Steel Corporation provided access to their property to establish a surface and ground water data collection network. Numerous private land owners provided information for their wells and access to their property.

\section{CLIMATE}

The study area has a subtropical climate characterized by warm and humid weather. According to U.S. National Weather Service records (Frentz and Lynott, 1978), the average annual temperature is about $17^{\circ} \mathrm{C}$. January is generally the coldest month with an average temperature of $6.7^{\circ} \mathrm{C}$, and July the hottest with an average temperature of $26.5^{\circ} \mathrm{C}$. The length of the growing season averages 225 days, with the frost-free season occurring from late March through early November.

The average annual precipitation, almost all in the form of rain, is about $1,400 \mathrm{~mm}$. Snowfall is very light and infrequent. During the period December through April, about 55 percent of the average annual precipitation occurs. The wettest month is March and the driest is October; drought conditions seldom occur. Summer rains, produced by convective storms are more intense but briefer and smaller in area than rains associated with winter and early spring frontal storm systems.

Precipitation in and near the study area in 1977 exceeded the long-term mean annual precipitation. During the first half of 1978, however, precipitation was well below normal. Monthly precipitation data at nearby Bankhead Lock and Dam are shown on figure 2 .

\section{TOPOGRAPHY AND LAND USE}

Topography in the two areas of study is similar. Maximum relief is about 100 meters with numerous tributaries incised sharply into shale and sandstone that support ridges and steep slopes. Most basins are separated by sharp ridges. This is modified somewhat in part of the southernmost area where sand and clay overlie the harder rocks. In this area, hilltops and ridges tend to be less sharp and, in places, relatively flat. Most roads are on ridges and most land development is along the roads and in the flatter areas.

A land-use inventory based on aerial photography flown February 21, 1977, indicates the study areas are largely undisturbed and relatively free of most activities that significantly affect the availability and distribution of water and its quality. About 5 percent is in rural development and light industry. Variations in land use between Bear and Blue Creek basins, and Turkey and Yellow Creek basins are given in table 1. The major land-use activity adjacent to the areas studied is surface coal mining. At the time of the inventory, only one small abandoned coal mine, located in Blue Creek basin, was present in the areas studied. Since then, another surface mining operation was started in early 1978. 


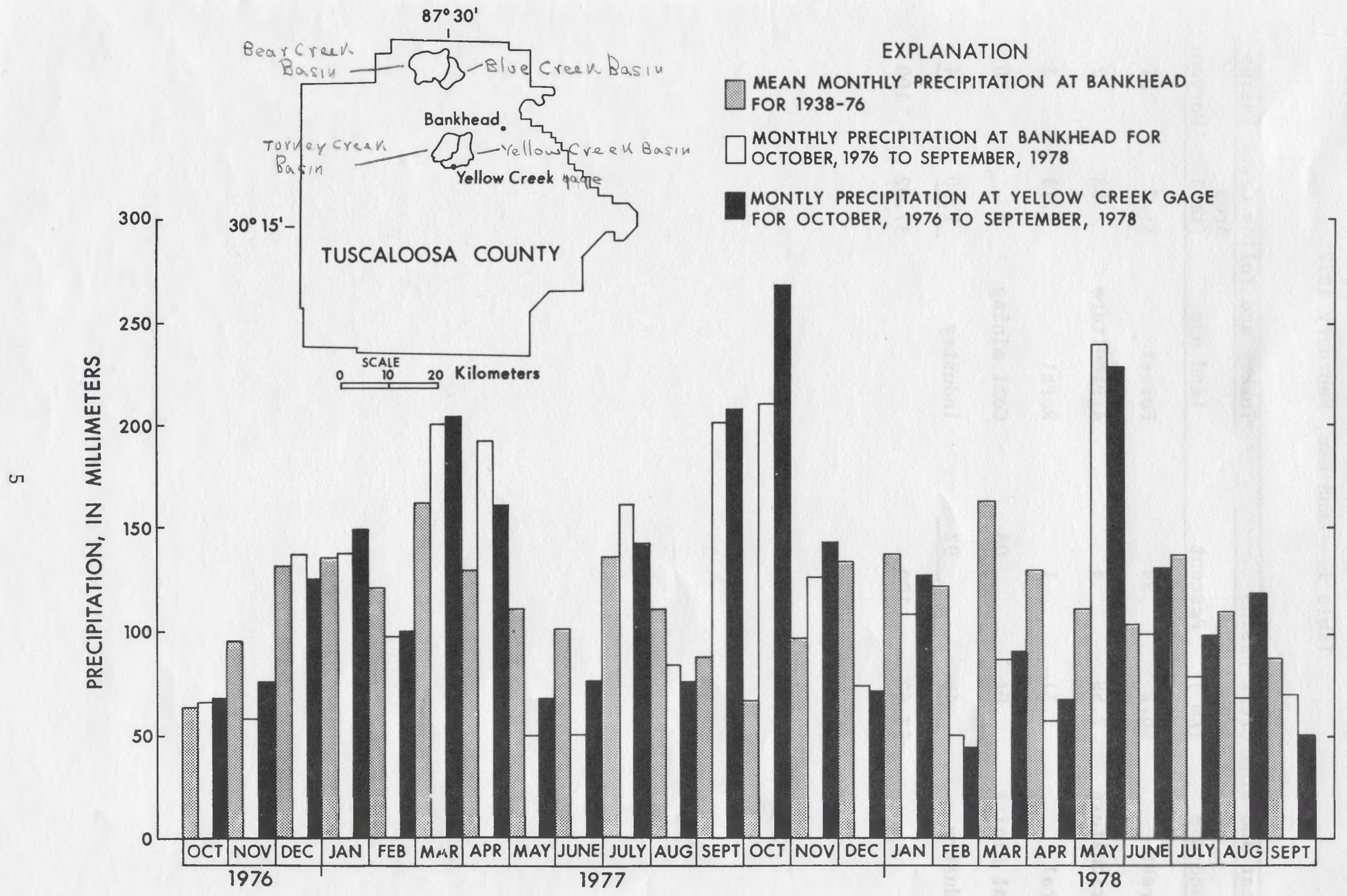

Figure 2.--Monthly precipitation in and near the study area. 
Table 1.--Land use, February 1977

\begin{tabular}{|c|c|c|c|c|c|}
\hline \multicolumn{3}{|c|}{ Bear and Blue Creek basins } & \multicolumn{3}{|c|}{ Turkey and Yellow Creek basins } \\
\hline Land use & $\begin{array}{l}\text { Area } \\
\left(\mathrm{km}^{2}\right)\end{array}$ & Percent & Land use & $\begin{array}{l}\text { Area } \\
\left(\mathrm{km}^{2}\right)\end{array}$ & Percent \\
\hline Forest & 50.2 & 94 & Forest & 33.7 & 91 \\
\hline Agriculture & 2.59 & 4 & Agriculture & .88 & 2 \\
\hline Rural & .31 & 1 & Rural & 1.14 & 3 \\
\hline Coal mining & .04 & .08 & Coal mining & 0 & 0 \\
\hline Industry & .48 & .92 & Industry & 1.30 & 4 \\
\hline & 53.62 & 100 & & 37.02 & 100 \\
\hline
\end{tabular}


The areas of study are in the outcrop of the Pottsville Formation of Pennsylvanian age and the overlying Coker Formation of Late Cretaceous age (p1. 1). The two formations are sedimentary in origin but contrast greatly; the Pottsville is consolidated and the Coker is unconsolidated. Regionally, strata in the Pottsville in the Warrior coal field strike northwestward and dip southwestward from about 6 to $30 \mathrm{~m} / \mathrm{km}$ (Culbertson, 1964). The unconformable contact between the Pottsville and overlying Coker Formation strikes northwestward and dips southwestward from about 6 to $7 \mathrm{~m} / \mathrm{km}$ (Paulson and others, 1962). The dip and strike of strata in the Coker Formation parallel those of the contact.

The Pottsville Formation in the area of study generally ranges in thickness from 820 to $1,000 \mathrm{~m}$ (Metzger, 1965). The lower part consists predominantly of orthoquartzitic sandstone and conglomerate. Middle and upper parts consist chiefly of shale, sandstone, and siltstone. These strata are generally medium to dark gray and carbonaceous, micaceous, and fossiliferous to some degree; some are calcareous. Shale is the dominant rock type.

Several intervals in the Pottsville Formation contain beds of coal and underclay. In the Warrior field, the productive part of the formation contains 7 coal groups that contain 2 to 10 beds each (Culbertson, 1964). These groups are, in ascending order, the Black Creek, Mary Lee, Pratt, Cobb, Guin, Utley, and Brookwood. Coal beds cropping out in the areas of study are in the Utley and Brookwood groups.

The Coker Formation in Tuscaloosa County is as much as $150 \mathrm{~m}$ thick, however, only the lower $37 \mathrm{~m}$ crop out in the area of study. The basal 8 to 30 $m$ generally consist of fine- to coarse-grained sand, gravelly sand, and sandy gravel separated in places by lenticular beds of gray, sandy clay. One or more thin beds of ferruginous cemented sandstone or conglomerate are usually present near the base of the formation. Strata overlying the basal unit consist largely of thin-bedded to massive clay and sandy clay with occasional beds of fine- to medium-grained sand.

Variations in the geology of the two areas result in large differences in their hydrology. The areas were selected to evaluate these differences to aid in determining the impact that surface coal mining will have on each.

\section{BEAR AND BLUE CREEK BASINS}

Segments of Bear and Blue Creek basins are underlain by the Coker and Pottsville Formations (p1. 1). The Coker, dipping southwestward about $6 \mathrm{~m} / \mathrm{km}$, crops out in less than 5 percent of the area. It is present in thin outliers capping the highest hills and ridges along basin divides.

Strata in the Pottsville exposed in this area are about $90 \mathrm{~m}$ thick and about $900 \mathrm{~m}$ above the base of the formation (Metzger, 1965). They generally 
strike northwestward and dip southwestward about 1 to $5 \mathrm{~m} / \mathrm{km}$ except where disrupted by faulting and folding. The Wiley Dome, the most prominent structural feature in the vicinity, is in and adjacent to the southeast part of the area. The configuration of the structure, based on contours of the Utley coal group, is on the base shown in figure 3. The structural anomalies and the general lithology of strata in the area are shown along a profile in plate 2 .

The shale and siltstone sequence is interrupted by a prominent sandstone, informally called the "Utley Sandstone" (Shotts, 1967), underlying and present in the lowermost part of the Utley coal group (p1. 2). The sandstone, generally interbedded with some shale and siltstone, ranges in thickness from 12 to $15 \mathrm{~m}$.

A11 coal beds cropping out in the area are in the Utley coal group. The occurrence and distribution of the basal coal bed in northern Tuscaloosa County has been defined by Shotts (1967). Culbertson (1964) also defined the group as consisting of 2 to 6 coal beds in a vertical interval of 6 to $46 \mathrm{~m}$ that is $75 \mathrm{~m}$ above the Guin coal group and 60 to $90 \mathrm{~m}$ below the Brookwood coal group.

The Utley group in the area of study consists principally of three coal horizons. One or more coal beds separated by partings may be present in each horizon. The basal coal bed (horizon 1 ) is the most persistent and thickest. The second horizon is 3 to $6 \mathrm{~m}$ above the basal bed and the third horizon 9 to $12 \mathrm{~m}$ above the basal bed. The two upper horizons are inconsistent in that either or both may be present or absent in a given area. For example, horizons 1 and 2 are present in the north part of the cross section on plate 2, horizons 1 and 3 are present on the south flank of the fold shown, and all horizons are present at the south end of the profile. Locally, other thin coal beds may be present below horizon 1 , above horizon 3, or between horizons 1 and 3 . As many as five thin beds have been observed in a $23 \mathrm{~m}$ interval in a single well.

The basal coal bed in the Utley group generally ranges in thickness from a trace to $61 \mathrm{~cm}$. Larger amounts may be available where multiple beds are present in the same horizon. Lesser thicknesses are generally in the overlying horizons with the thinnest occurring at the top.

\section{TURKEY AND YELLOW CREEK BASINS}

The lower parts of Turkey and Yellow Creek basins are in the outcrop of the Pottsville Formation and the upper parts in the outcrop of the overlying Coker Formation (p1. 1). Strata in the Pottsville strike east and northeast and dip south and southeast about 5 to $6 \mathrm{~m} / \mathrm{km}$. This dip and strike is reflected by structure contours on the base of the Utley coal group (fig. 4). The Coker Formation strikes northwestward, and dips southwestward about 6 to $7 \mathrm{~m} / \mathrm{km}$. Lithologies of the formations penetrated in test wells are shown on plate 3 .

Strata in the Pottsville Formation cropping out in Turkey and Yellow Creek basins have a maximum thickness of about $75 \mathrm{~m}$. This stratigraphic interval is 


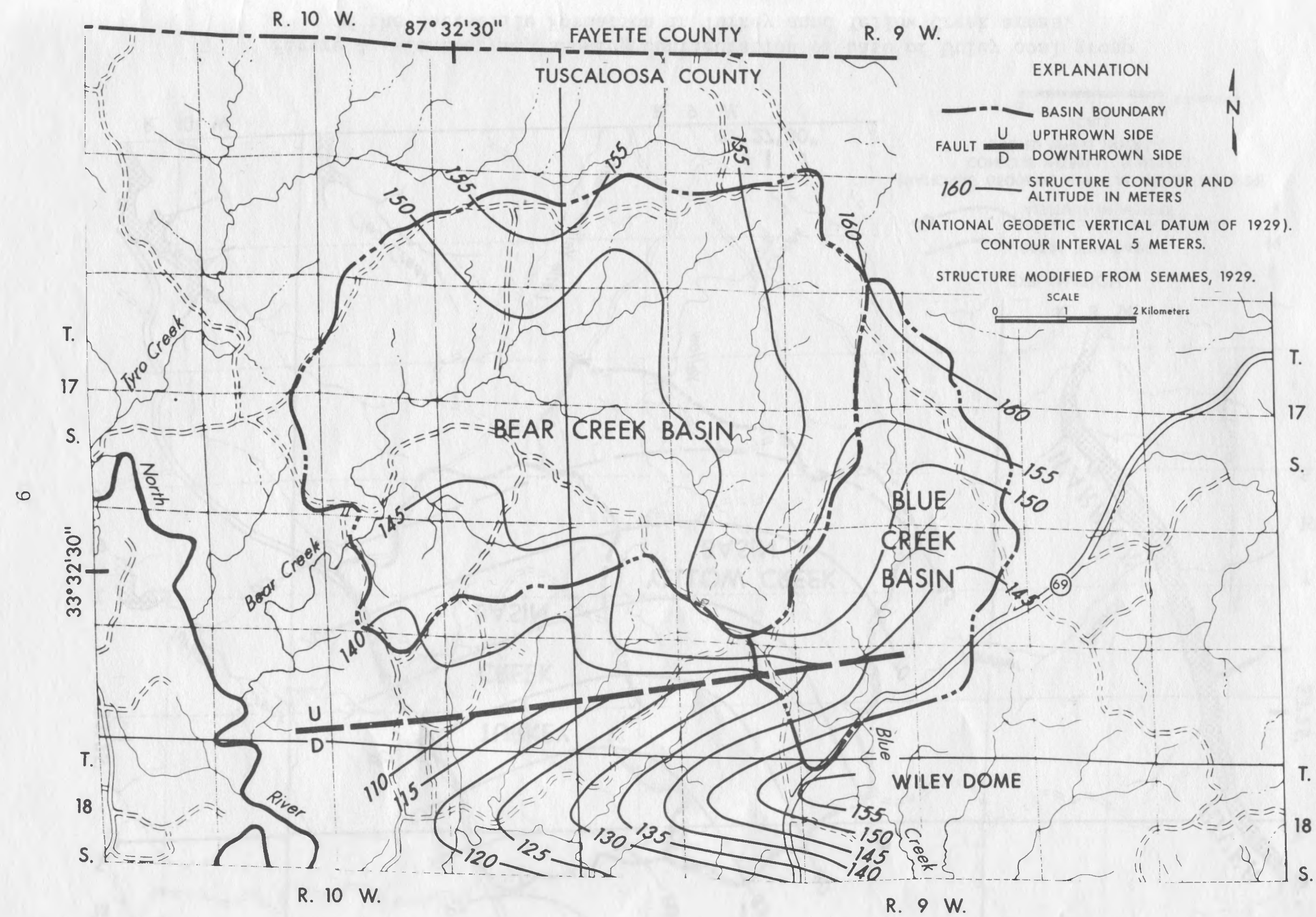

Figure 3.--Contour map showing configuration of base of Utley coal group of the Pottsville Formation in Bear and Blue Creek areas. 


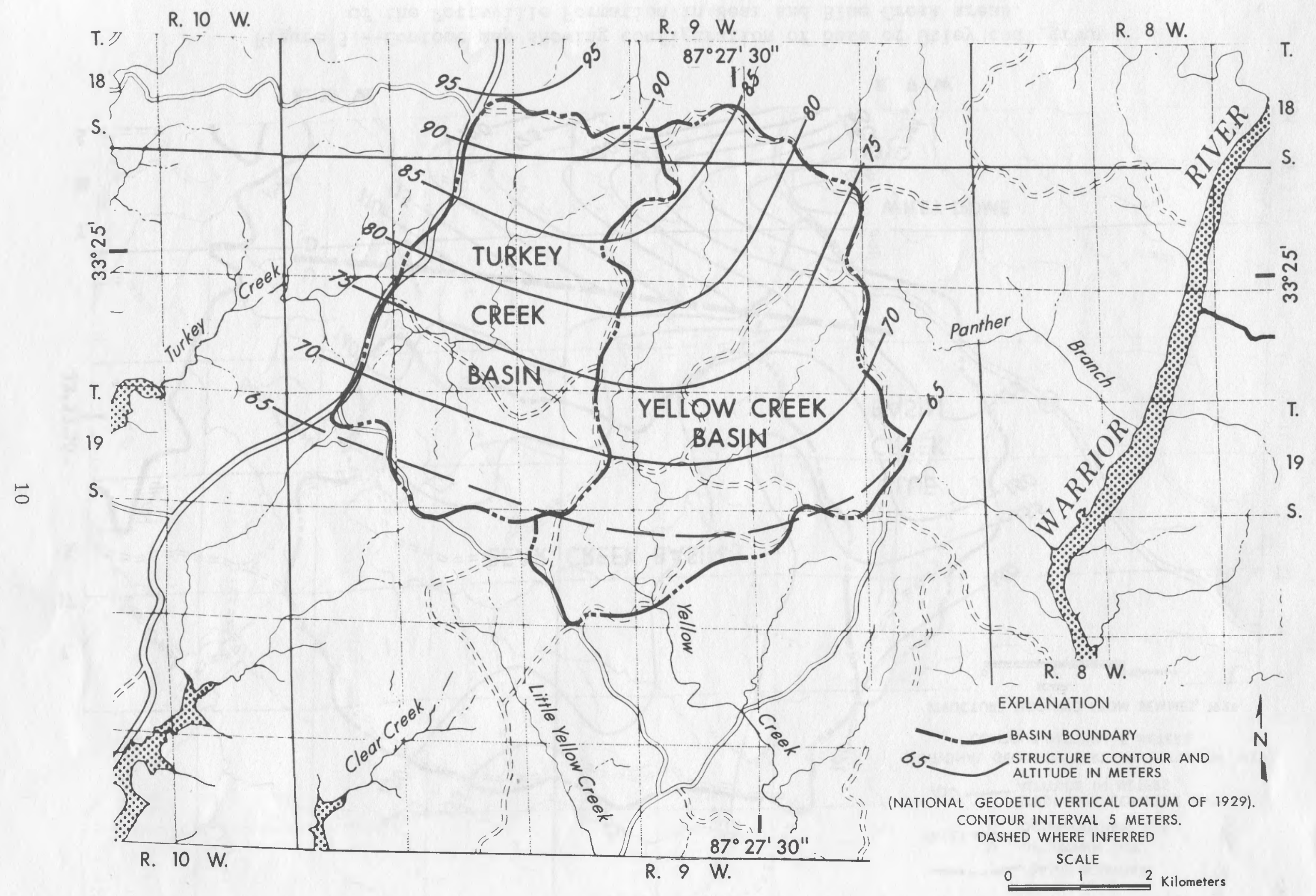

Figure 4.--Contour map showing configuration of base of Utley coal group of the Pottsville Formation in Turkey annd Yellow Creek areas. 
about 1,075 $\mathrm{m}$ above the base of the Pottsville Formation (Metzger, 1965). The interval consists chiefly of light-gray to dark-gray shale, siltstone, and sandstone.

Coal beds cropping out in Turkey and Yellow Creek basins are in the Brookwood coal group. The basal bed is 60 to $70 \mathrm{~m}$ above the top of the Utley coal group. The Brookwood group consists of five coal beds that, in ascending order, are: Clements, Johnson (Carter), Milldale, Brookwood, and Guide (Culbertson, 1964). The Clements is thin or absent along most of its outcrop and the Guide is thin and present only locally (Culbertson, 1964), thus, no attempt is made here to assign proper names to coal beds in the area. Coal exposures are rare due to colluvium from the overlying Coker Formation and the scarcity of road cuts. Coal beds penetrated in test wells were as much as $58 \mathrm{~cm}$ thick. The two lowermost beds are shown on plate 3 .

The Coker Formation is as much as $37 \mathrm{~m}$ thick in this study area. Its basal sand and gravel beds contrast greatly with a massive light- to medium-gray plastic clay at the top of the Pottsville Formation. The clay, commonly 2 to $7 \mathrm{~m}$ thick, is the leached remnant of shale or argillaceous sandstone and usually grades downward into these rock types. In weathered indistinct exposures, the contact is commonly marked by a prominent spring line discharging from the base of the Coker. This contact is of particular significance to the occurrence and movement of water.

GROUND WATER

The Pottsville and Coker Formations have extremely diverse water-bearing characteristics. Most indurated rocks in the Pottsville are relatively impermeable whereas unconsolidated sand and gravel in the Coker is permeable.

Quantitative data are not available to evaluate the hydraulic characteristics of the Pottsville or Coker Formations in the basins studied. The descriptions of the occurrence, storage, and movement of ground water in the respective basins are based on geology, well inventory, and limited information obtained from a test-drilling program during the preparation of this report. The locations of wells inventoried and test wells drilled in 1978 are shown on plate 4 and information for them is given in tables 2 and 3 . Wells outside the study basins were included in the inventory due to the scarcity of information in some places and anticipation of future work in nearby mining areas.

Ground water in the Pottsville occurs primarily in openings along fractures and bedding planes. Most fractures in the relatively impermeable consolidated rocks are limited in size, and the amount of water stored in and transmitted through them is small. Openings or fractures are more numerous where rocks have been subjected to weathering and variations in temperatures. Data in a previous study (Paulson and others, 1962), indicate the possibility of getting a water supply at depths greater than about $75 \mathrm{~m}$ is remote because deeper strata are less weathered and contain fewer openings. Paulson and others (1962) also recognized that little is known concerning recharge and movement of ground water in the formation. 
Basal unconsolidated sands in the Coker Formation yield water to many wells in north Tuscaloosa County. The areas of study are underlain by the lower part of the formation in its recharge area. In all but the southernmost part of the study area (Turkey and Yellow Creek basins), the Coker occurs only as outliers not interconnected with the main body of the formation.

\section{BEAR AND BLUE CREEK BASINS}

Sands in the Coker Formation, because of their thinness and limited area of outcrop on hilltops and ridges, probably will not yield supplies adequate for domestic use.

The Pottsville Formation is the only aquifer tapped by wells in the basins of Bear and Blue Creeks. Wells tapping the formation in and immediately adjacent to the basins (p1. 4 and table 2) range in depth from 7.9 to $87.2 \mathrm{~m}$. Of the 45 wells ror which depths are available, 15 are less than $15.2 \mathrm{~m}$ deep and 30 are less than $30.5 \mathrm{~m}$ deep. Only two springs are utilized as sources of supply.

The average yield of wells tapping the Pottsville is probably less than $0.3 \mathrm{~L} / \mathrm{s}$. To locate an adequate domestic supply, several test wells are sometimes necessary. Yields from the deeper wells appear to be similar to those obtained at shallower depths. In many instances, the deeper wells do no more than provide storage for small quantities of water entering at shallower depths.

The most easily recognized water-bearing zones in the Pottsville are fractures in coal beds and in the harder rocks. Springs or seeps most commonly discharge from fractures in rocks and coal beds during wet months. Without precipitation, most cease flowing in a short period of time.

Recharge to the aquifer is probably transmitted largely by a network of fine fractures at shallow depths. When relatively impermeable strata such as shale or underclay is encountered, water moves through the openings in the direction of dip. The dip of strata is generally southward except in the southernmost part of the area where the dip reverses on the flank of the Wiley Dome (fig. 3). The fault along the north flank of the dome may be a potential source of large quantities of ground water. Ground water, if its movement is the same as the dip of the strata, should be moving toward the fault from the north and south.

\section{TURKEY AND YELLOW CREEK BASINS}

The Pottsville Formation crops out in lower parts of the basins and is overlain by permeable unconsolidated sand and gravel in the Coker Formation. The two formations, their different rock types and attitudes, and their relationship to topography are shown on a cross section in plate 3. Turkey and Yellow Creek basins differ from those of Bear and Blue Creek in that the Coker Formation is more widespread and is thicker.

Sand and gravel beds at the base of the Coker Formation are the principal sources of domestic water supply. Of 20 wells inventoried in and immediately adjacent to this area, 16 tap the Coker. These wells, 11 of which are shallow 
dug wells, range in depth from 2.7 to $30.5 \mathrm{~m}$. In addition to the we11s, 11 springs discharging from the base of the formation are utilized as sources of domestic supply.

The maximum yield available from the Coker Formation is about $6.4 \mathrm{~L} / \mathrm{s}$ and this can probably be obtained only locally along the south margin of the area where its permeable beds are thickest. The yield available to wells in central and northern parts of the area, especially near its outcrop boundaries and where it is thin, would probably be less than $0.3 \mathrm{~L} / \mathrm{s}$.

The saturated zone at the base of the Coker is thin in most areas and is perched on clay at the top of the Pottsville Formation. Recharge to the Coker, because of its permeability, is discharged readily by one of the most prominent spring lines in Alabama. Numerous springs discharge from the contact in all but its northeasternmost exposures in the area of recharge. Individual springs utilized for domestic supplies generally discharge 0.06 to $0.3 \mathrm{~L} / \mathrm{s}$.

The Pottsville Formation yields water to 4 wells in or immediately adjacent to the study area. These wells had depths of 40.2 to $101 \mathrm{~m}$. Yields from these wells are probably similar to those in Bear and Blue Creek basins.

Little is known concerning the recharge to and movement of ground water in the Pottsville Formation. Most recharge enters openings during periods of rainfal1; other recharge probably enters openings exposed in tributaries fed by the numerous perennial springs emerging in hillsides from the base of the overlying Coker Formation. Additional recharge probably enters the Pottsville directly from the saturated basal sand and gravel in the overlying Coker. This occurrence may be limited, however, the prominent clay at the top of the Pottsville appears to be an effective confining bed. The direction of movement of water in openings along bedding planes not intersected by fractures is downdip toward the south and southeast (fig. 4).

\section{GROUND WATER QUALITY}

Most of the data available to evaluate the quality of ground water are field determinations. In this study, the determinations are specific conductance and $\mathrm{pH}$ (table 2). A limited number of more comprehensive analyses are given in table 4. Definition of some constituents and characteristics in both tables are as follows :

Dissolved solids.--Consist mainly of the dissolved mineral constituents in water and is represented by the residue that remains after evaporation and drying at a temperature of $180^{\circ} \mathrm{C}$.

Hardness. --A physical-chemical characteristic that is commonly recognized by the increased quantity of soap required to produce lather. It is attributable to the presence of alkaline earths (principally calcium and magnesium) and is expressed as equivalent calcium carbonate $\left(\mathrm{CaCO}_{3}\right)$. The following scale (Durfor and Becker, 1964) is used in this report to assist the reader in appraising degrees of hardness: 
Degree of hardness

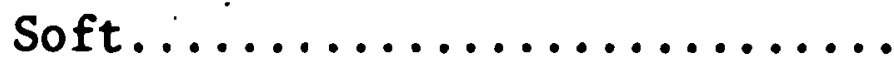

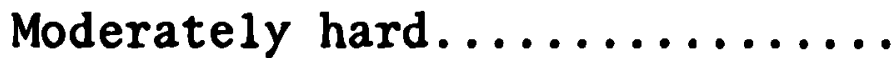

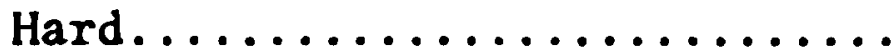

Very hard....................
Hardness range

(mg/L)

$$
\begin{gathered}
0-60 \\
61-120 \\
121-180 \\
>180
\end{gathered}
$$

$\mathrm{pH}$.--A measure of the hydrogen-ion concentration of a solution. A pH unit is the negative $\log _{10}$ of the hydrogen-ion concentration. The $\mathrm{pH}$ of pure water is 7.0 , acid water has a smaller $\mathrm{pH}$ and alkaline water a larger $\mathrm{pH}$.

Specific conductance.--A measure of the ability of water to conduct an electrical current and is expressed in micromhos per centimeter at $25^{\circ} \mathrm{C}$. Specific conductance is related to the number and specific ions in solution, and it can be used for approximating the dissolved-solids concentration in water.

Water in the Pottsville Formation in Tuscaloosa County, based on Paulson and others (1962), generally had a hardness exceeding $100 \mathrm{mg} / \mathrm{L}$, a chloride concentration less than $20 \mathrm{mg} / \mathrm{L}$, and locally contains greater than $300 \mathrm{ug} / \mathrm{L}$ iron. Water in the Coker Formation, based on the same report, ranged in hardness from 6 to $130 \mathrm{mg} / \mathrm{L}$ and in chloride concentration from 0 to $156 \mathrm{mg} / \mathrm{L}$, and locally contained sufficient iron to cause staining (usually about $300 \mathrm{ug} / \mathrm{L}$ or more).

Analyses of water from six wells tapping the Pottsville Formation in Bear and Blue Creek basins (table 4) indicate that the water generally is hard but of good chemical quality. Constituents determined were present in quantities less than the recommended limits for drinking water defined by the U.S. Environmental Protection Agency (1977). The $\mathrm{pH}$ and specific conductance values are similar to field determinations made on water from 32 other Pottsville wells and springs (table 2) in or immediately adjacent to the same area (pl. 4). These field determinations of $\mathrm{pH}$ ranged from 4.6 to 7.6 with most being greater than 6.5 . The median $\mathrm{pH}$ was 6.8. Specific conductance ranged from 33 to 600 umho al though most exceeded 100 umho. The average specific conductance was about 226 umho.

The quality of water in the Pottsville Formation in Turkey and Yellow Creek basins is probably similar to that in Bear and Blue Creek basins to the north. Water in wells 35 and 36 (pl. 4 and table 2) have specific conductance and $\mathrm{pH}$ values similar to water in the Pottsville in the Bear and Blue Creek basins.

Water from five we1ls and springs in the Coker Formation in Turkey and Yellow Creek basins (table 4) is far less mineralized and more acidic than water in the Pottsville Formation. The water is soft and has a low dissolved solids concentration. The specific conductances ranged from 14 to 28 umho. Specific conductances for 25 of 27 additional wells and springs (table 2) in or immediately adjacent to the basins ranged from 12 to 96 umho; the median specific conductance was 23 umho. Water from the same wells and springs ranged in pH from 4.9 to 6.9 and had a median of 5.5. The remaining two wells (wells 27 and 44 in table 2) had specific conductances and pHs similar to those in the Pottsville. 
Other constituents in water in the Coker Formation (table 4) are not defined because of 1 imited data. The objectionable iron content in both the Pottsville and Coker Formations reported by well owners and investigators (Paulson and others, 1962) is not reflected by data collected for this study.

\section{SURFACE WATER}

The data collection sites to define streamflow and water quality parameters are shown on figure 5 . Information for the sites, including the type data co1lected, is given in table 5 .

The outflow gaging stations for Bear Creek (site 1), Blue Creek (site 3), and Yellow Creek (site 7) basins are instrumented for continuous streamflow data collection. Sites 1 and 7 are also instrumented to monitor specific conductance, water temperature and rainfall, and to collect daily suspended sediment samples. Streamflow and water-quality data are collected monthly and during flood events at sites $2,4,5$ and 6 . Biologic data are collected monthly at all sites.

\section{STREAMFLOW CHARACTERISTICS}

Streamflow characteristics are determined mainly by climate, topography, geology, and land use. Basins where these conditions are similar may have similar streamflow characteristics. Substantial differences in any of these conditions may result in a corresponding variation in streamflow.

The four basins studied have similar climate, topography, and land use. They are, however, in different geologic environments. Bear and Blue Creek basins are underlain primarily by the relatively impermeable Pottsville Formation whereas Turkey and Yellow Creek basins are underlain primarily by the permeable Coker Formation. Preliminary descriptions of streamflow characteristics in the two geologic environments are based primarily on 2 years of record collected from the instrumented sites.

\section{Streamf1ow Distribution}

Streamflow distribution generally reflects seasonal precipitation. Stream discharges are usually highest during November through April and lowest during May through October. The decline in streamflow during the latter period is due to lack of precipitation and the increase in evapotranspiration during the growing season. In late spring and summer, streamflow is mainly ground-water discharge from storage. Ground-water discharge and total streamflow generally increases during fall when evapotranspiration decreases and precipitation increases.

The daily mean discharges for sites 1 and 3 are shown on figure 6 and those for site 7 are shown on figure 7. Monthly and annual mean discharge are given in table 6. Maximum instantaneous discharge recorded at sites 1, 3, and 7 were $68 \mathrm{~m}^{3} / \mathrm{s}, 86 \mathrm{~m}^{3} / \mathrm{s}$, and $24 \mathrm{~m}^{3} / \mathrm{s}$, respectively. All occurred during a high 


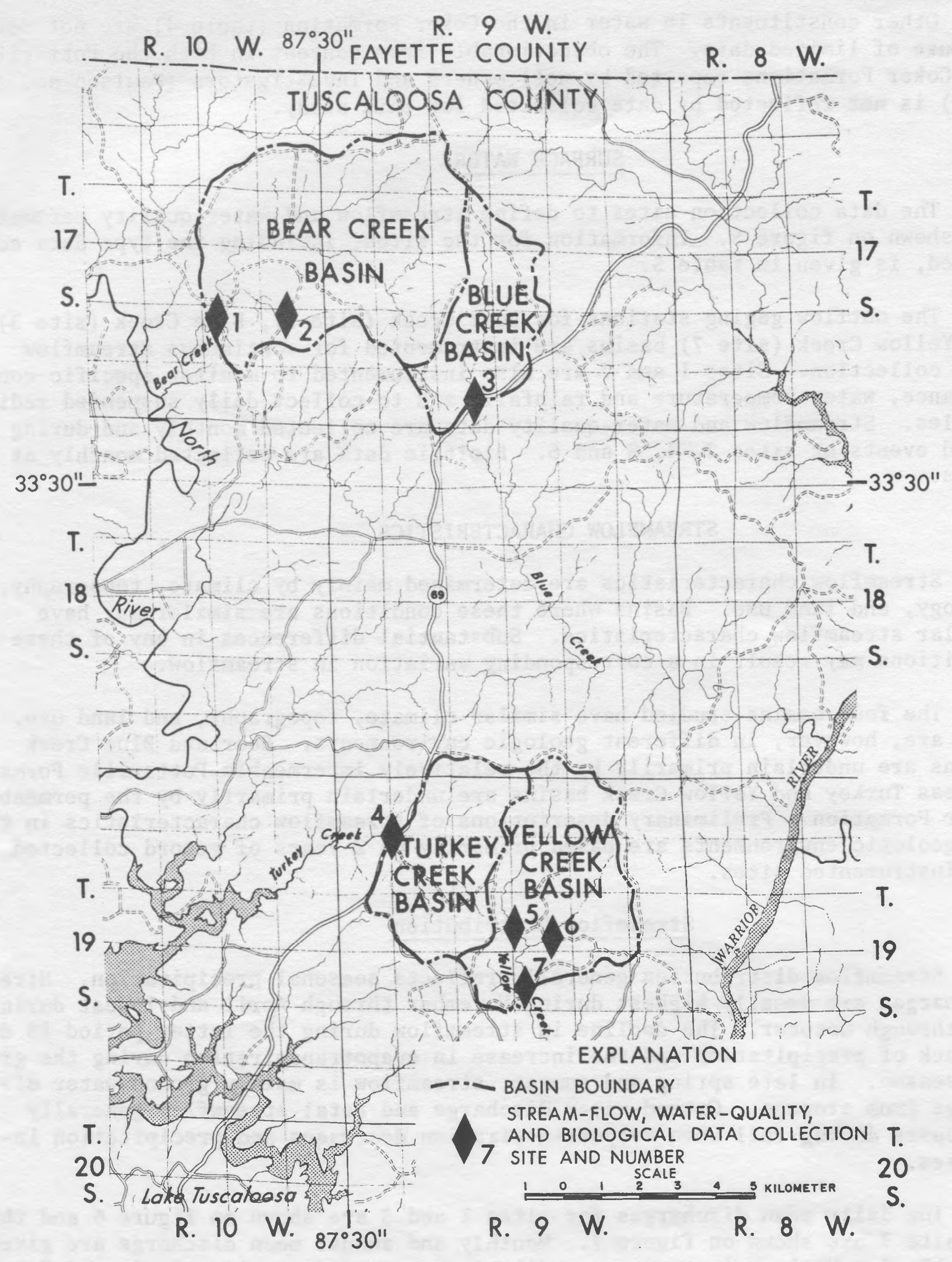

Figure 5.--Locations of surface-water data collection sites. 


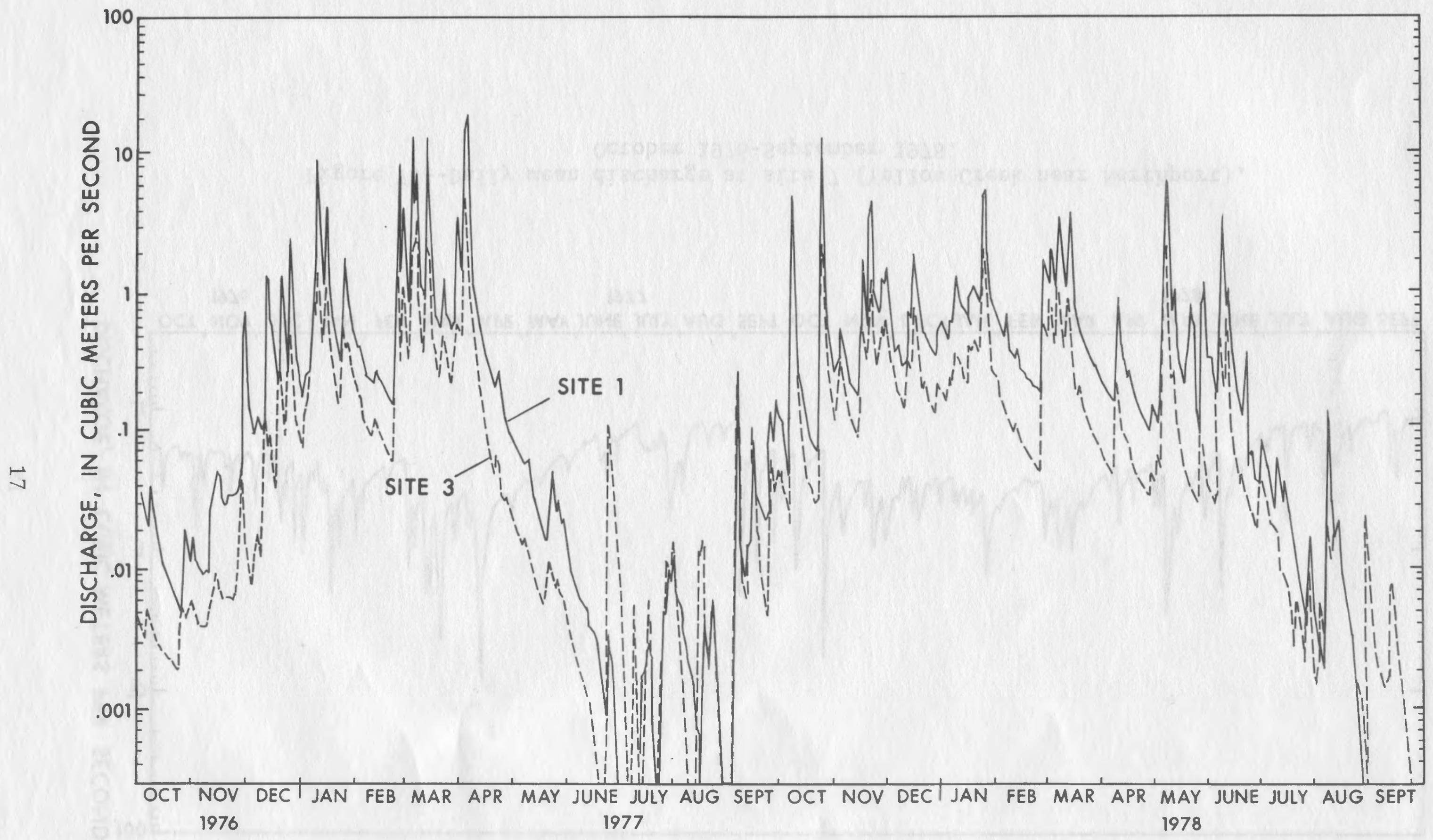

Figure 6.--Daily mean discharge at site 1 (Bear Creek near Samantha), and site 3 (Blue Creek near Oakman), October 1976-September 1978. 


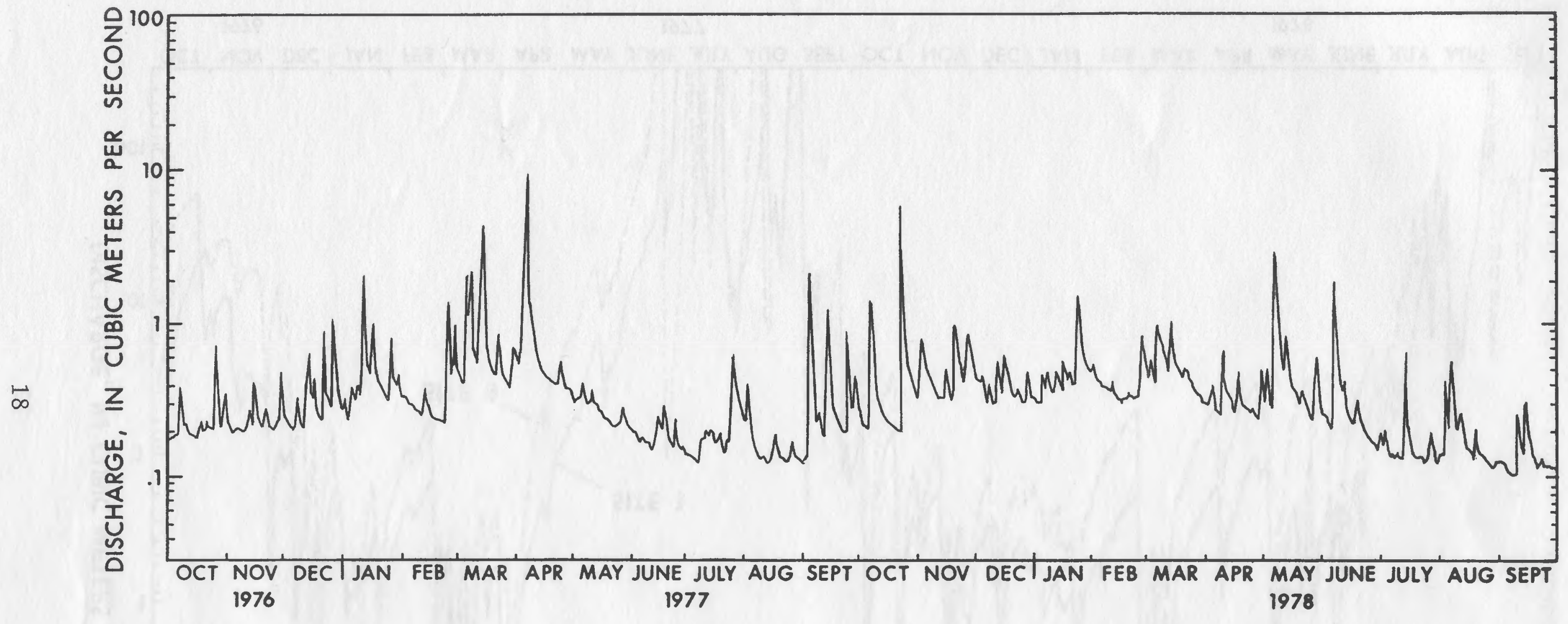

Figure 7.--Daily mean discharge at site 7 (Yellow Creek near Northport), October 1976-September 1978. 
intensity storm in April 1977. Sites 1 and 3 are frequently dry during the summer and early fall. The minimum instantaneous discharge of $0.10 \mathrm{~m}^{3} / \mathrm{s}$ at site 7 occurred in September 1978.

\section{Flow Duration and Variability}

Streamflow variability may be demonstrated with a flow-duration curve. It is a cumulative-frequency curve that shows the percent of time a specific discharge may be equaled or exceeded. It combines into one curve the flow characteristics of a stream throughout the range of discharge, without regard to the sequence of occurrence. It is only applicable to the period of record used to develop the curve. Climate, topography, and geology are generally the major factors that determine the shape of the flow-duration curve.

A steep curve denotes highly variable streamflow derived mainly from direct surface runoff, whereas a flat curve indicates streamflow derived from direct runoff and storage. The shape of the low flow portion of the curve is controlled mainly by the geology of the basin (Searcy, 1959). It reflects the contribution of ground water to streamflow.

Flow-duration curves for sites 1,3 , and 7 are shown in figure 8 . The curves were plotted in cubic meters per second per square kilometer for comparative purposes. The curves for sites 1 and 3 , very similar throughout the full range of flow, contrast with the curve for site 7 . The variation at medium and high discharges probably reflects differences in geology. The curves for sites 1 and 3 reflect the limited contribution of water from storage in the Pottsville Formation. The curve for site 7 is typical of streams with well sustained low flows; it reflects the contribution of water from storage in the Coker Formation underlying most of the basin.

\section{Low Flow}

The suitability of streams for some uses, with respect to water availability, is generally determined by low flow. The 7-day 2 -year $\left(7 Q_{2}\right)$ low flow is the discharge at the 2-year recurrence interval taken from a frequency curve of annual values of the lowest mean discharge for 7 consecutive days. During the 2-year study, the $7 Q_{2}$ for sites 1,3 , and 7 were 0,0 , and $0.005\left(\mathrm{~m}^{3} / \mathrm{s}\right) / \mathrm{km}^{2}$, respective1y. The values agree closely with those reported from previous low-flow investigations (Hayes, 1978; Peirce, 1967) for other nearby similar basins.

\section{SURFACE WATER QUALITY}

Sampling was scheduled to define water quality throughout the range of flow. Most samples were analyzed for concentrations of major constituents, selected nutrients (nitrogen-phosphorus series), and trace elements. Stream-bottom materials were also collected for trace element analyses. Most analyses have been published by the U.S. Geological Survey (1978-79) and will not be presented in this report. 


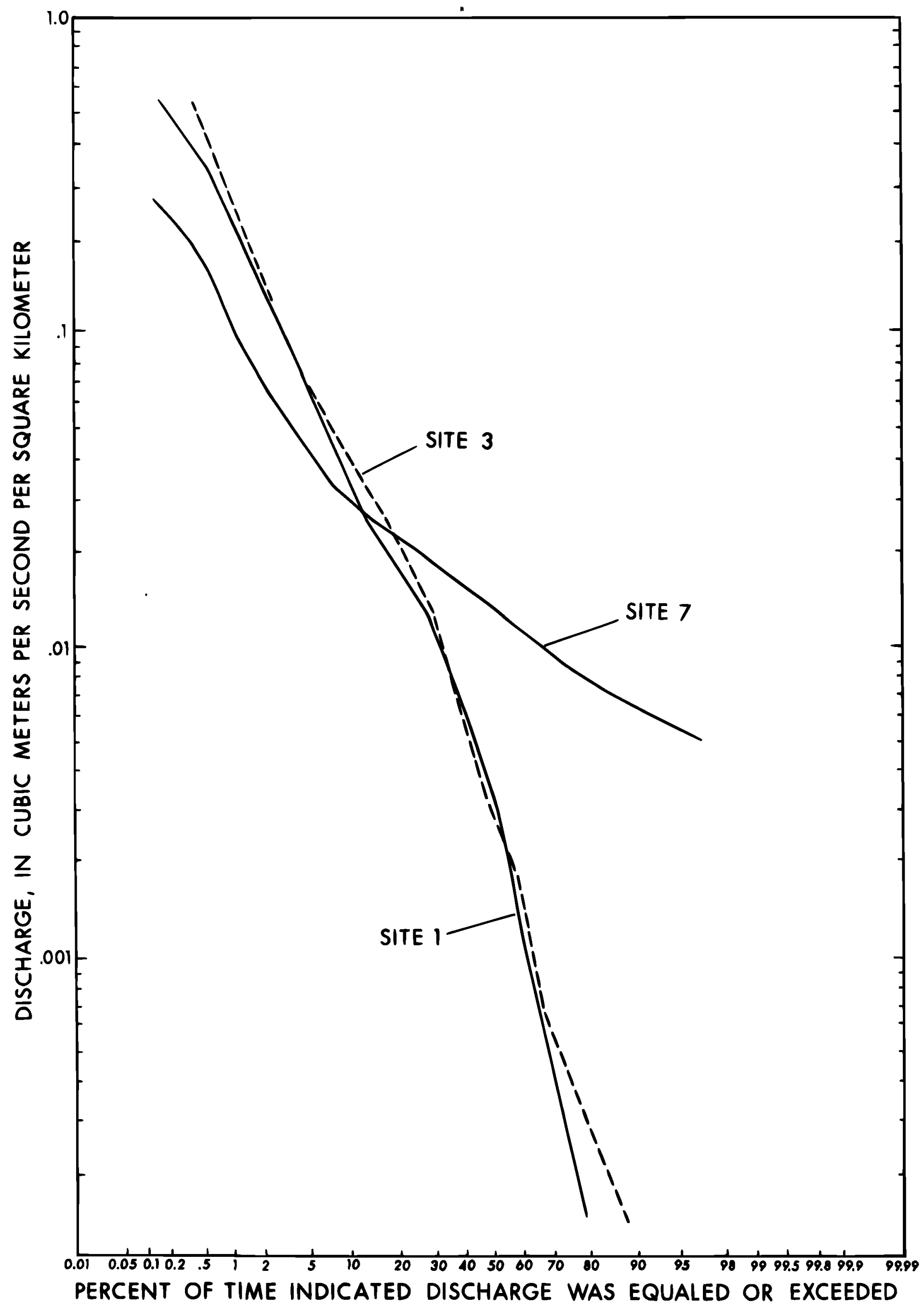

Figure 8.--Flow-duration curves for sites 1 (Bear Creek near Samantha), 3 (Blue Creek near Oakman), and 7 (Yellow Creek near Northport), October 1976-September 1978. 
Sources of chemical constituents in water are primarily from precipitation, contact with minerals, and man's cultural activities. Average values of selected physical and chemical properties of rainfall in nearby Tuscaloosa in 1973 and 1975 are given in table 7. This information, collected prior to the study, indicates the concentration of some constituents contributed by rainfall.

Table 7.--Mean values of selected physical and chemical constituents of rainfall in Tuscaloosa, Alabama in 1973 and 1975

(Based on five chemical analyses)

\begin{tabular}{|c|c|}
\hline Constituent & Mean \\
\hline Specific conductance $(u m h o) \ldots \ldots \ldots \ldots \ldots \ldots$ & 13 \\
\hline Calcium, $m g / L \ldots \ldots \ldots \ldots \ldots \ldots \ldots \ldots \ldots \ldots \ldots$ & .60 \\
\hline Magnesium, mg/L. & .10 \\
\hline Sodium, $\mathrm{mg} / \mathrm{L} . .$. & .64 \\
\hline Potassium, mg/L. . & .20 \\
\hline Bicarbonate, $\mathrm{mg} / \mathrm{L}$. & .80 \\
\hline Sulfate, $m g / L . . . \ldots$. & 1.2 \\
\hline Chloride, mg/L...... & 1.3 \\
\hline Nitrate, $\mathrm{mg} / \mathrm{L} . . . .$. & .42 \\
\hline
\end{tabular}

1/ Median value.

Physical Properties and Major Constituents

Variations in specific conductance, water temperature, and stream discharge at sites 1 and 7 are illustrated in figures 9 and 10 . The inverse relation between specific conductance and stream discharge at site 1 results from base flow contributed by the Pottsville Formation. During periods of little or no precipitation, streamflow mainly consists of ground-water inflow, while during periods of heavy precipitation, most streamflow is derived from overland flow. The chemical quality from each source can be substantially different. Base flow from the Pottsville is more mineralized than overland flow, thus a decrease in overland flow results in an increase in specific conductance. Little seasonal variation in specific conductance occurs at site 7 on Yellow Creek (fig. 10). Water in the Coker Formation (table 4) is very similar to rainwater (table 7), therefore, decreases in overland flow result in little variation in specific conductance. Variations in monthly mean water temperatures accompanied variations in seasonal air temperatures.

Water-quality data collected at individual stream sites are summarized in tables 8 through 14 , and the chemical composition of stream discharge and relationship between suspended sediment and discharge for all sites are illustrated on figures 11 through 17 . Surface water in the study area is generally acidic, soft, and low in dissolved solids. Dissolved solids ranged from 12 to $112 \mathrm{mg} / \mathrm{L}$. Water in all streams ranged in $\mathrm{pH}$ from 4.6 to $7: 5$. Water in streams draining the Coker was generally more acidic than water in streams draining the Pottsville. 


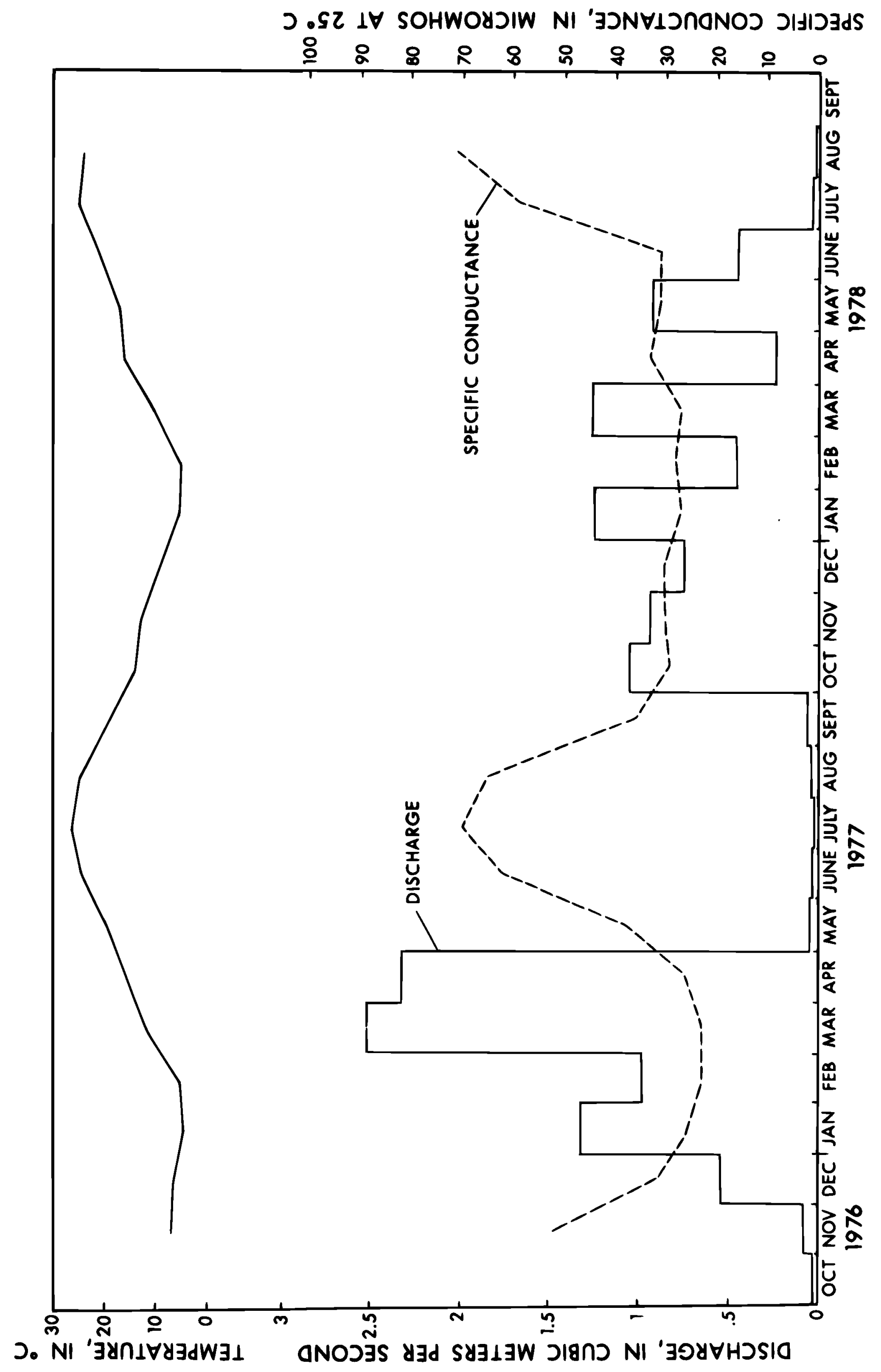

Figure 9.--Variations in monthly mean stream discharge, specific conductance, and water temperature at site 1 (Bear Creek near Samantha). 


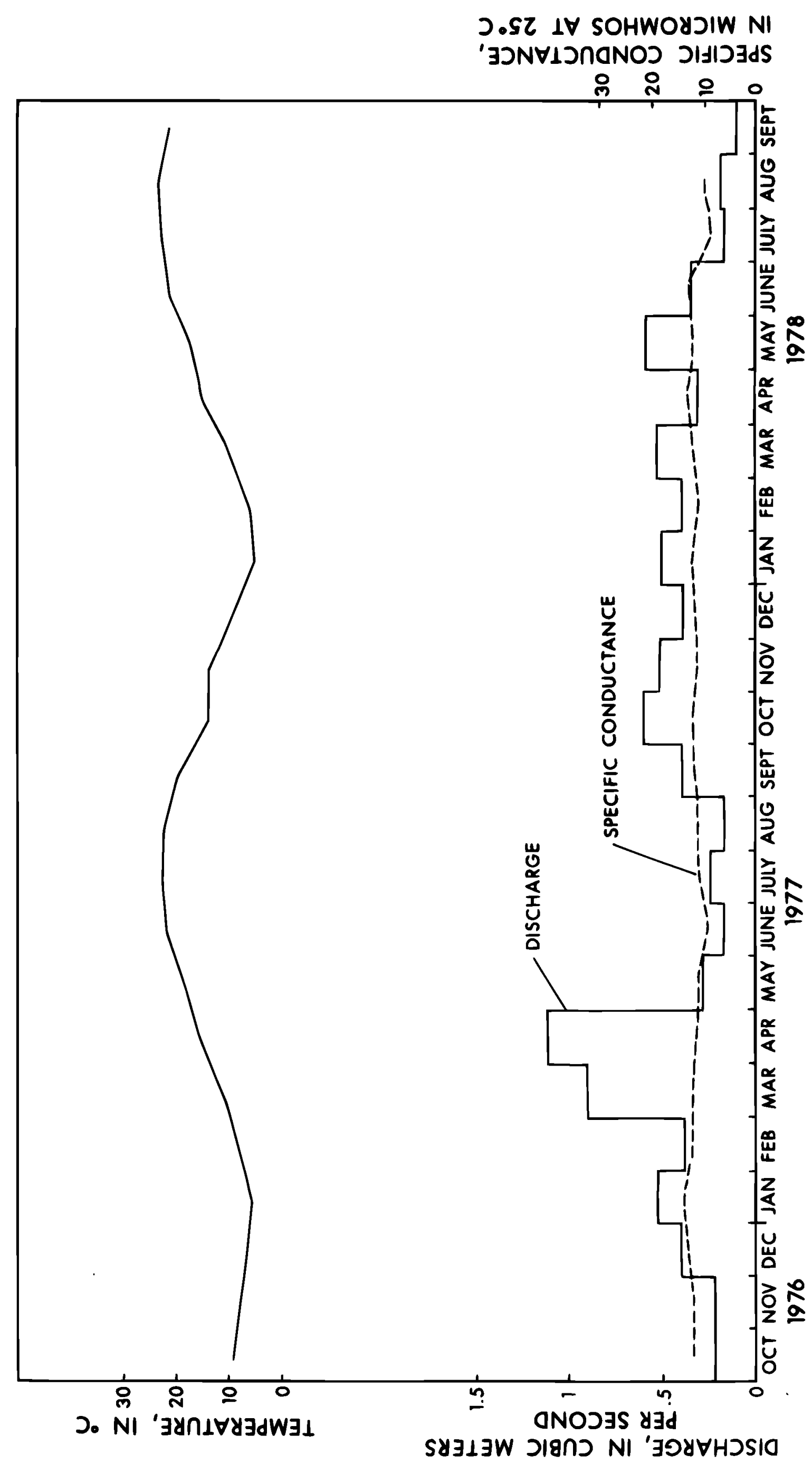

Figure 10.--Variations in monthly mean stream discharge, specific conductance, and water temperature at site 7 (Yellow Creek near Northport). 


\section{CHEMICAL COMPOSITION OF WATER}

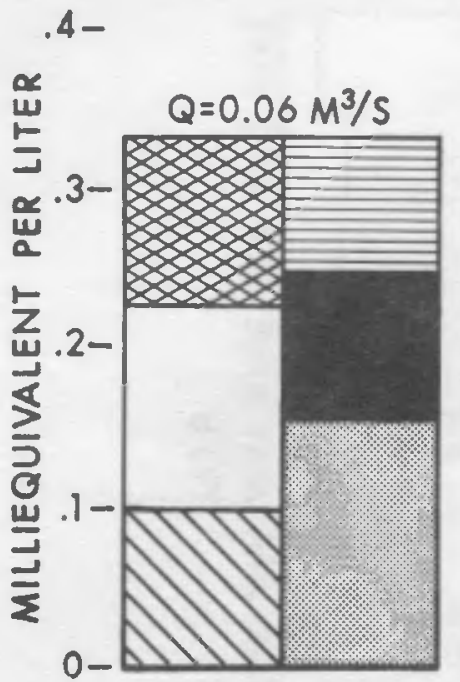

DEC. 6, 1976
$Q=30.0 \mathrm{M}^{3} / \mathrm{S}$

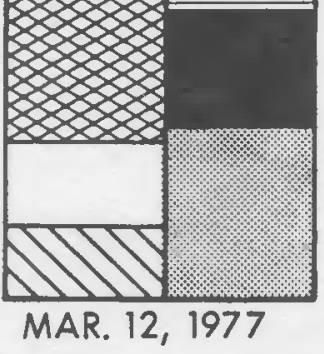

EXPLANATION

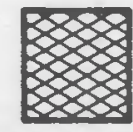

$\mathrm{Na}+\mathrm{K}$
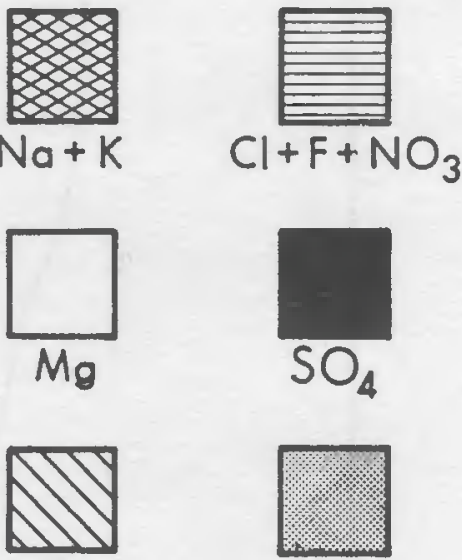

$\mathrm{Ca}$

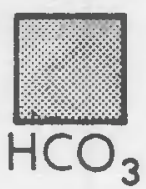

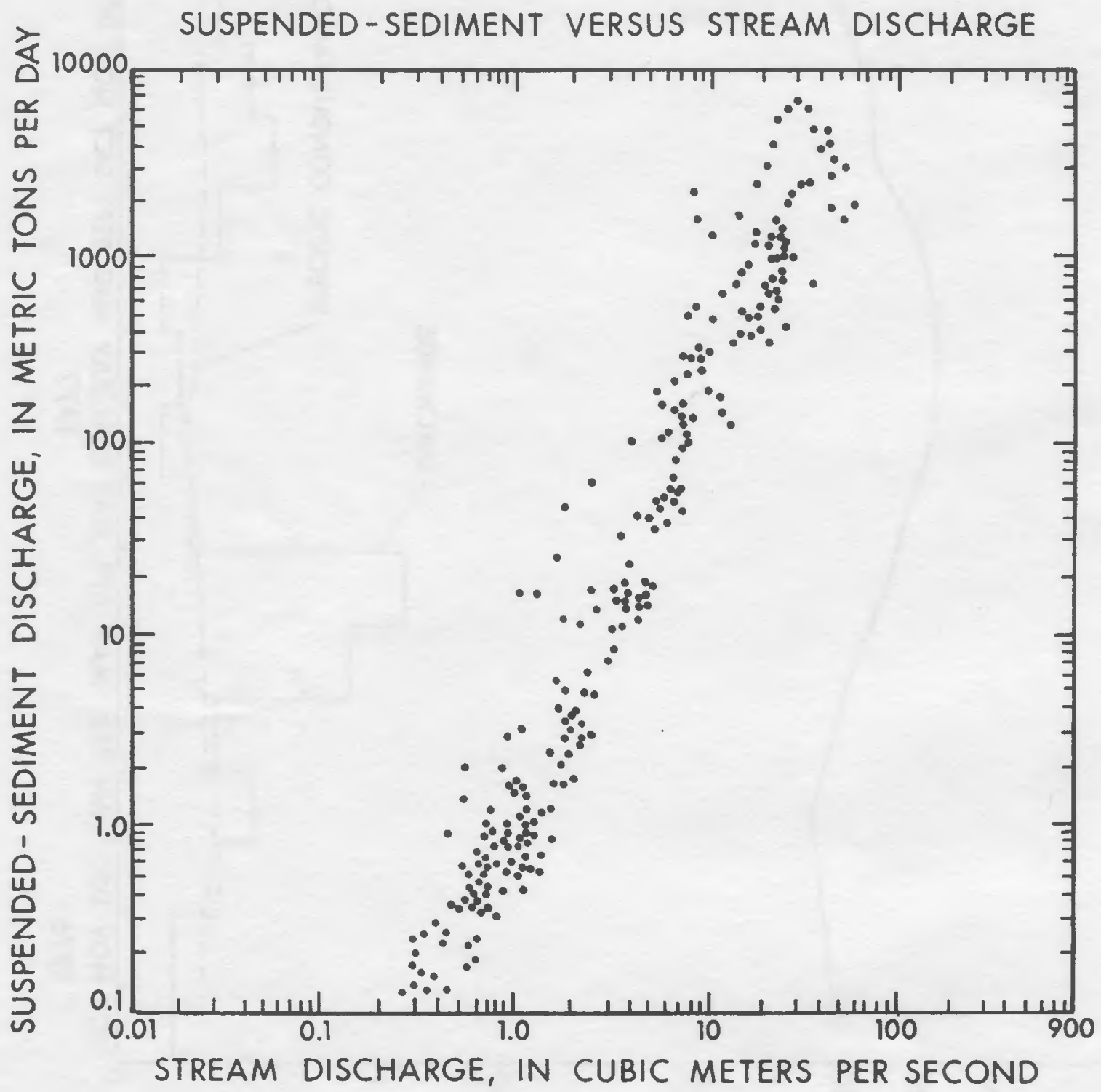

Figure 11.--Chemical composition of stream discharge (Q), and relationship between suspended sediment and stream discharge at site 1 (Bear Creek near Samantha). 


\section{CHEMICAL COMPOSITION OF WATER}

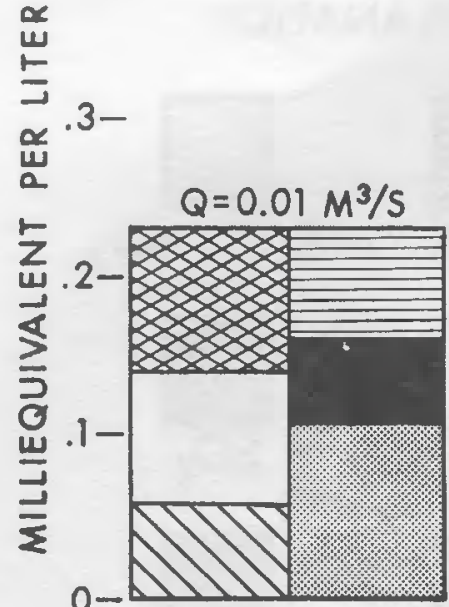

DEC. 6,1976

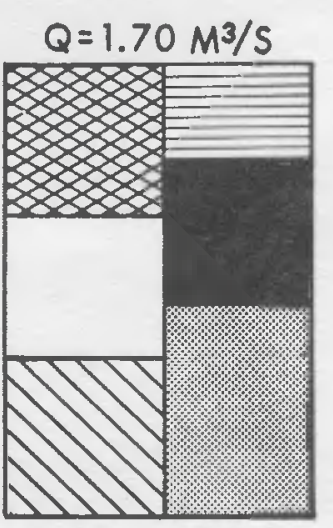

MAR. 4, 1977
EXPLANATION

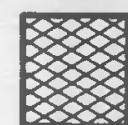

$\mathrm{Na}+\mathrm{K}$
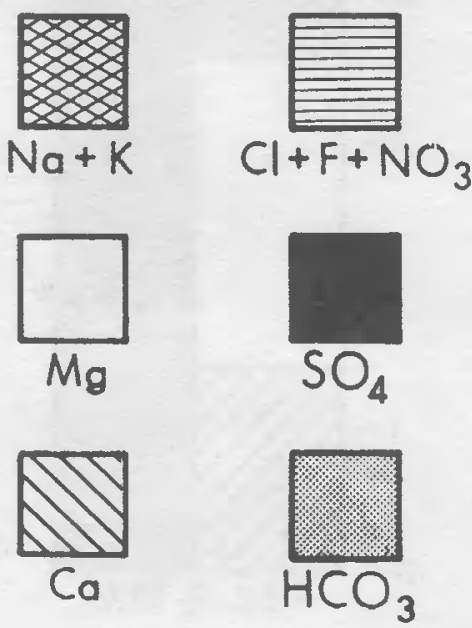

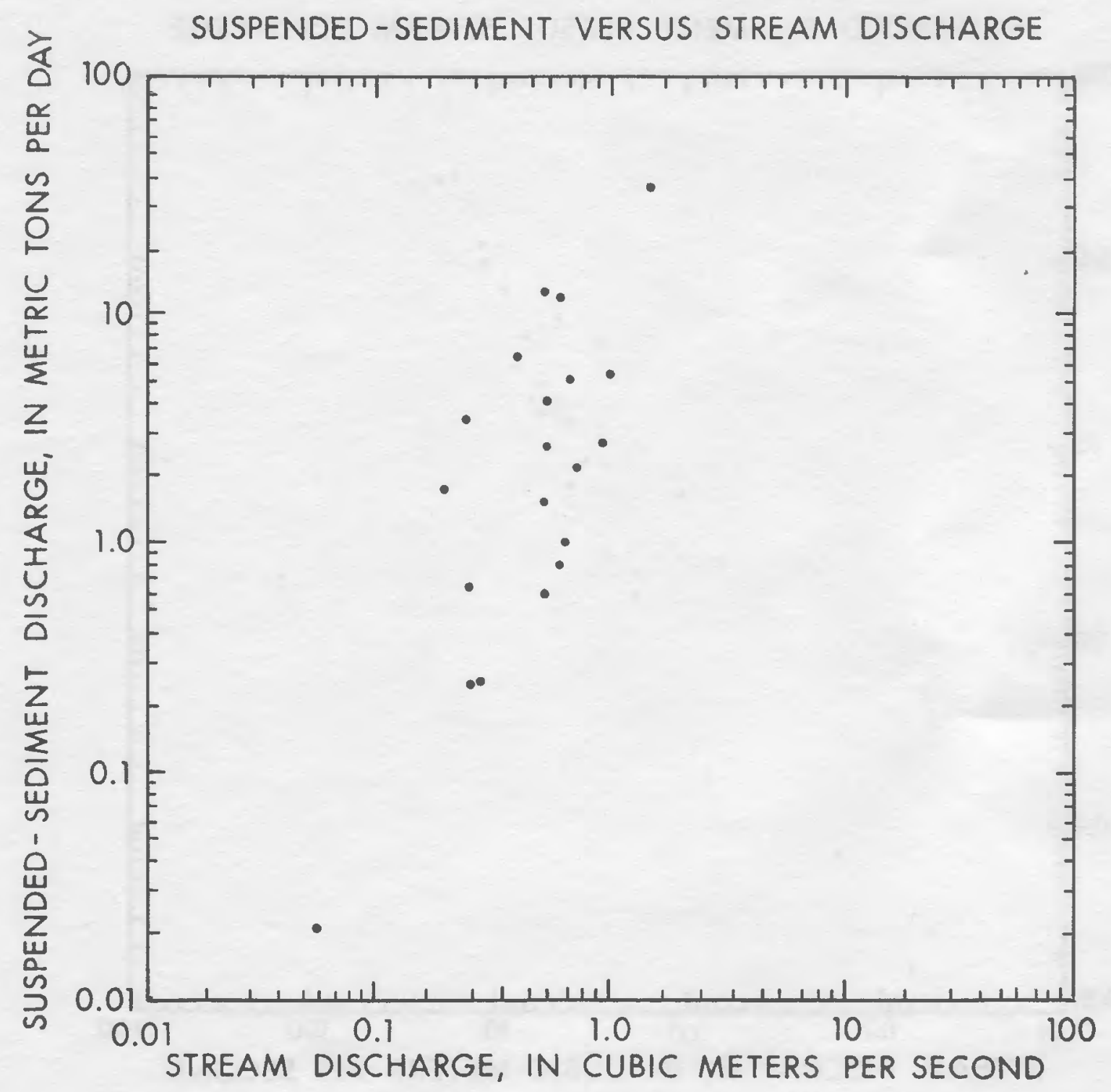

Figure 12.--Chemical composition of stream discharge (Q), and relationship between suspended sediment and stream discharge at site 2 (Dry Branch near Samantha). 

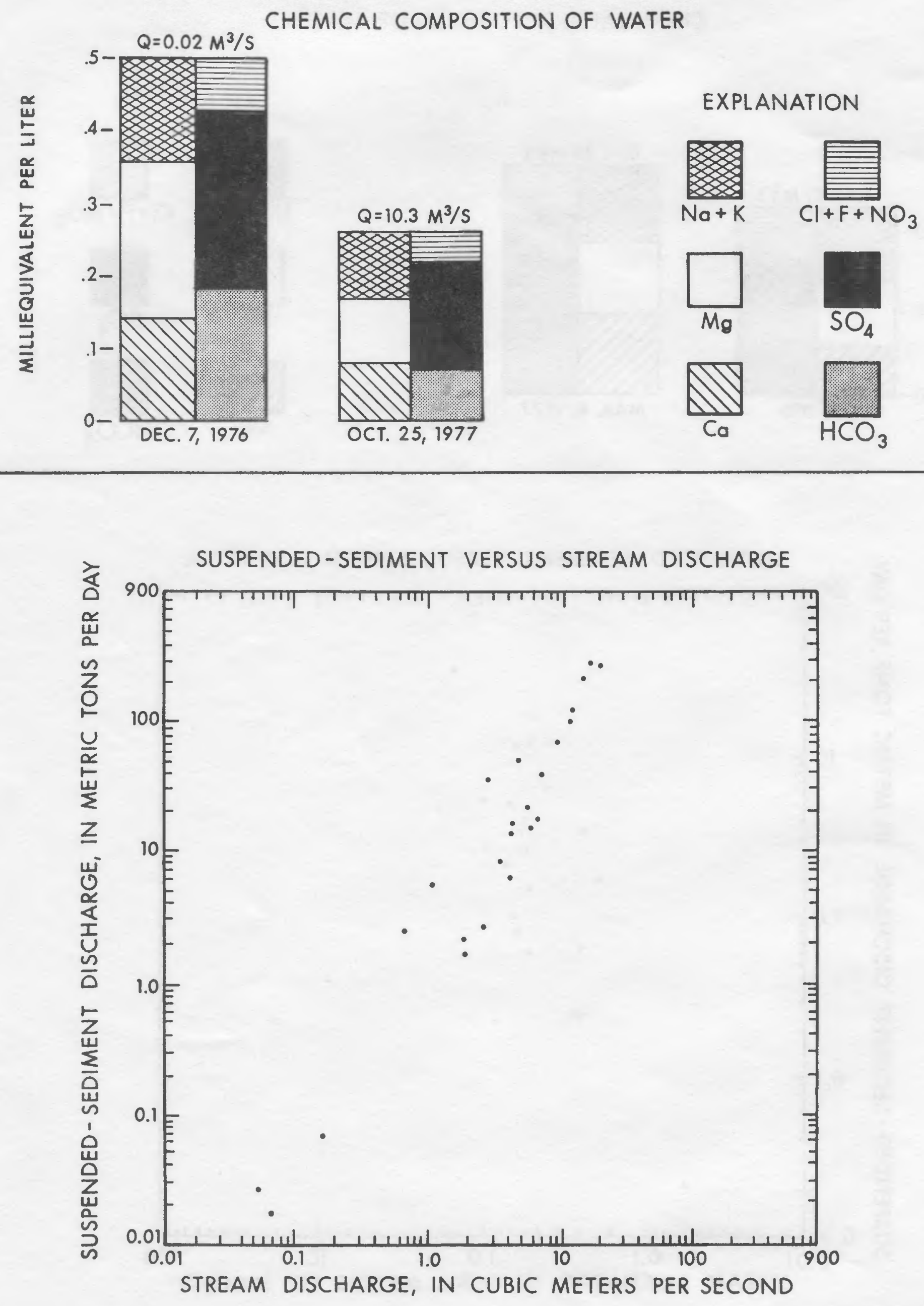

Figure 13.--Chemical composition of stream discharge (Q), nd relationship between suspended sediment and stream discharge at site 3 (Blue Creek near Oakman). 


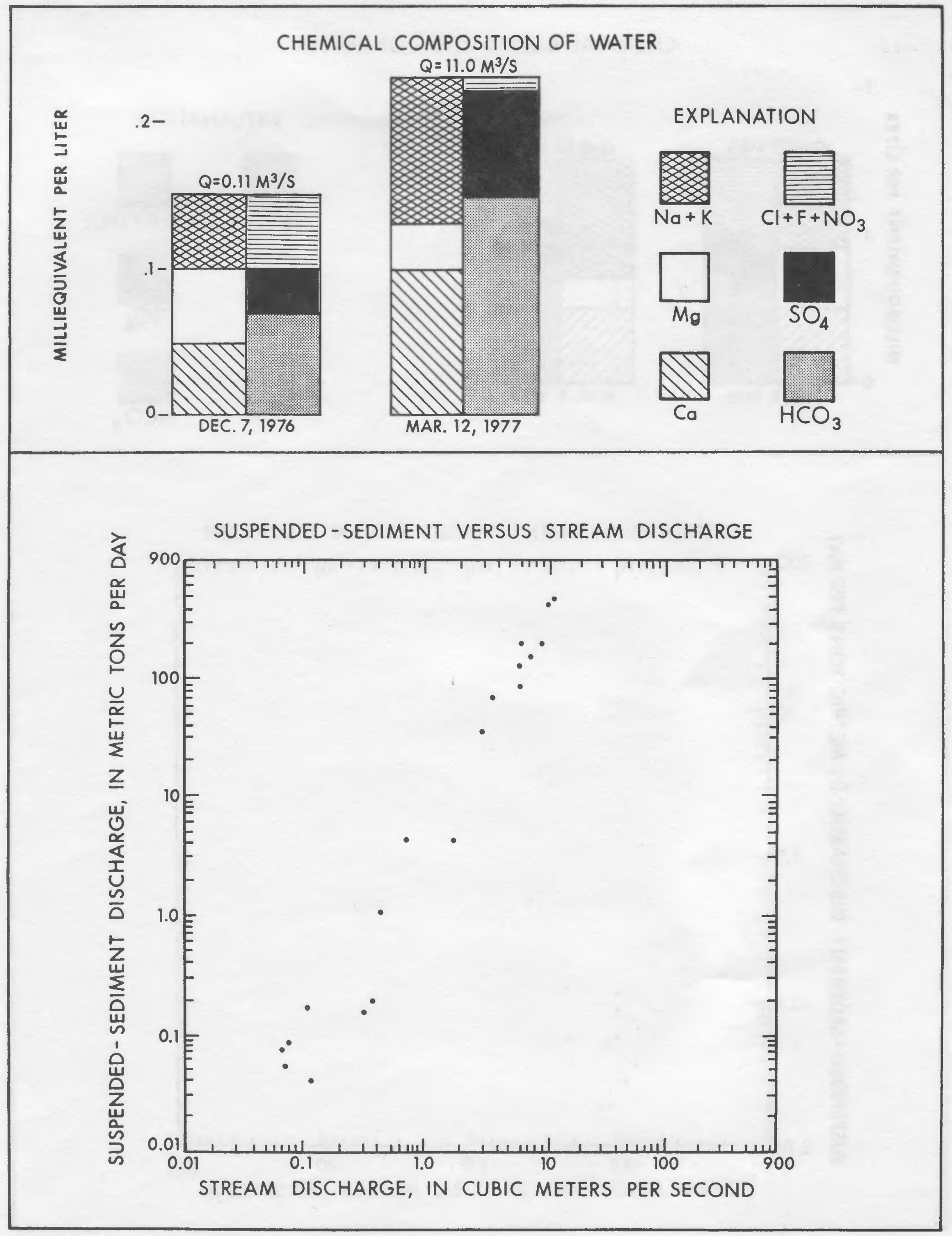

Figure 14.--Chemical composition of stream discharge (Q), and relationship between suspended sediment and stream discharge at site 4 (Turkey Creek near Tuscaloosa). 


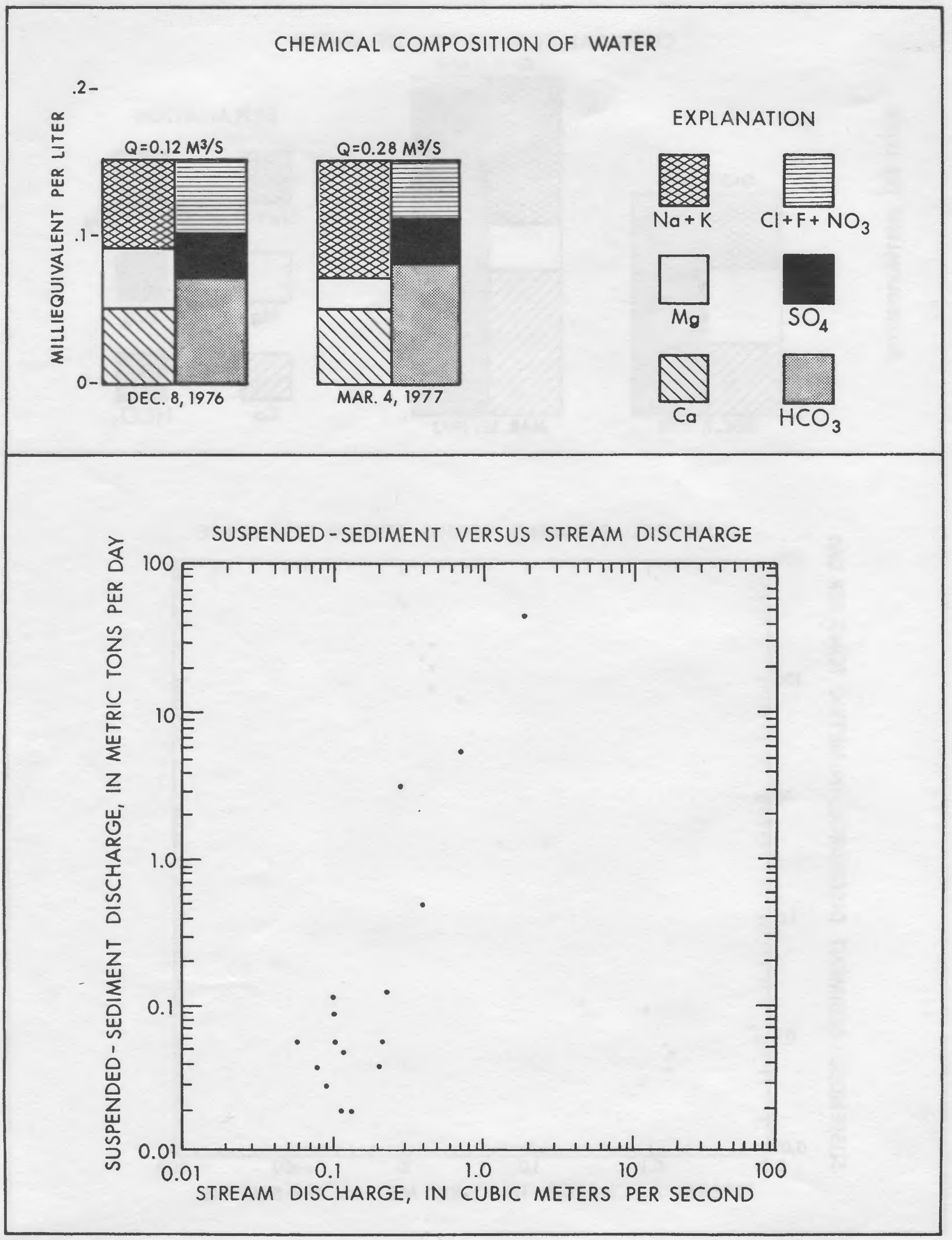

Figure 15.--Chemical composition of stream discharge (Q), and relationship between suspended sediment and stream discharge at site 5 (Yellow Creek above Northport). 


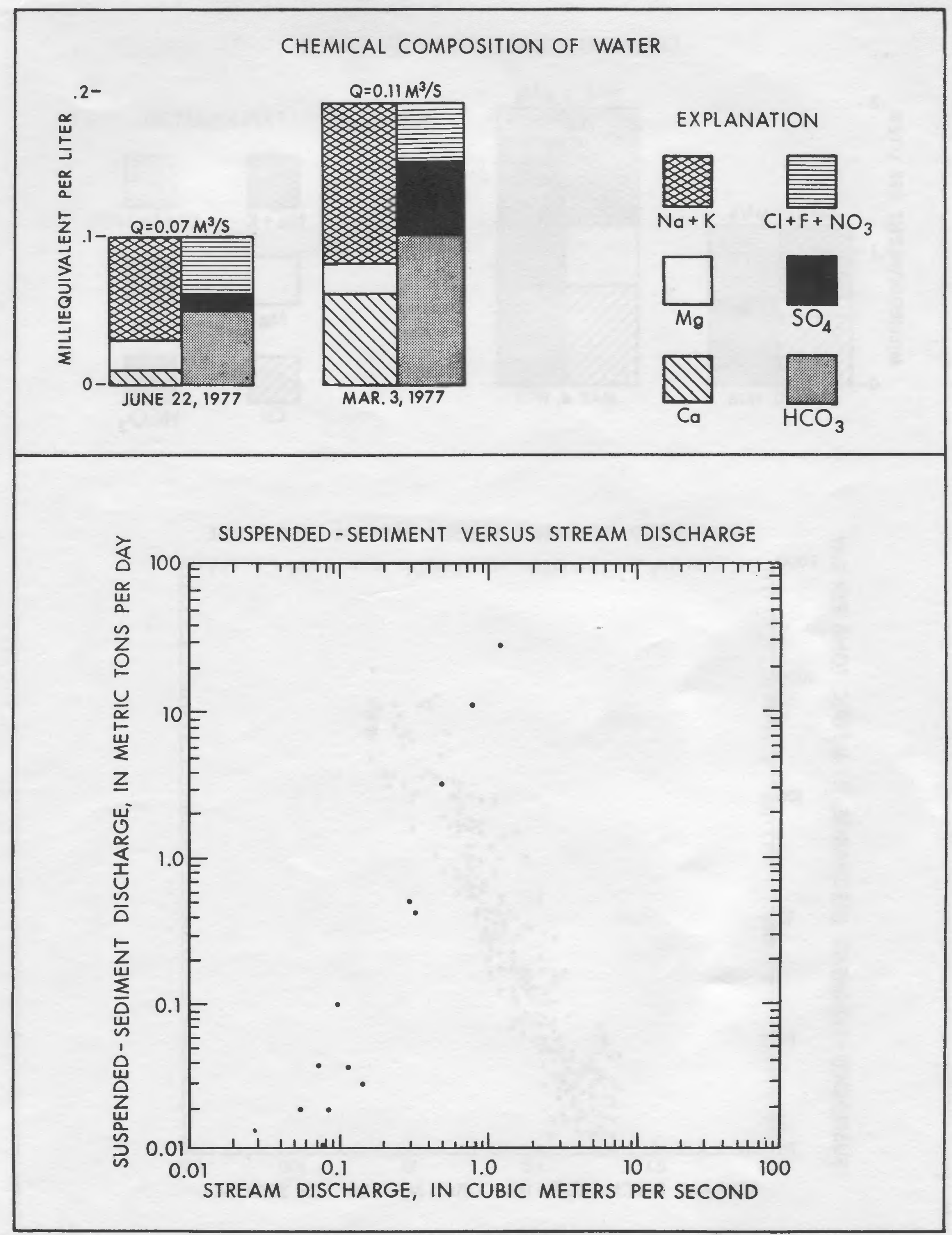

Figure 16.--Chemical composition of stream discharge (Q), and relationship between suspended sediment and stream discharge at site 6 (tributary to Yellow Creek near Northport). 


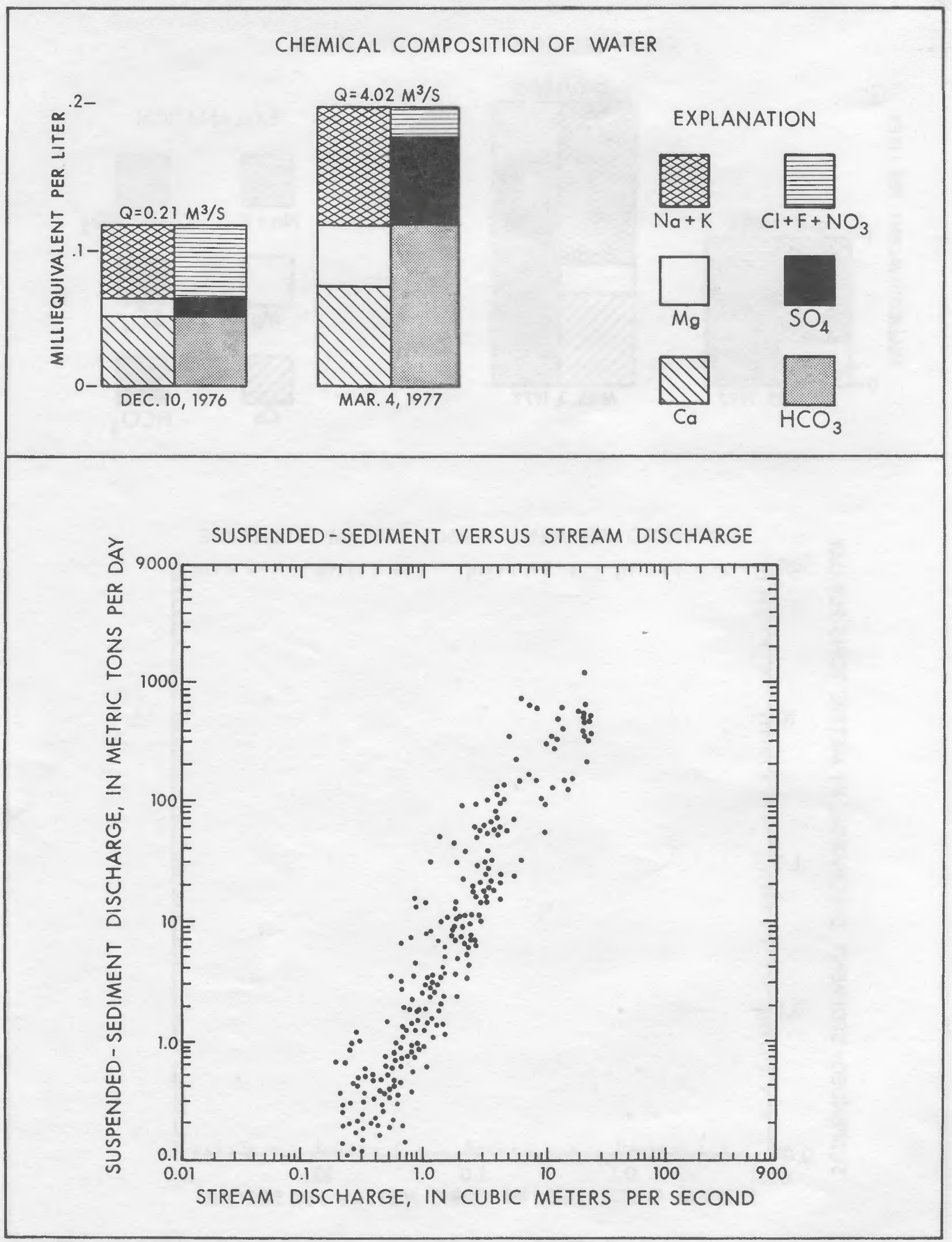

Figure 17.--Chemical composition of stream discharge (Q), and relationship between suspended sediment and stream discharge at site 7 (Yellow Creek near Northport). 
Water quality at site 3 (fig. 13 and table 10) varies differently from that at other sites. The water is, at times, moderately hard and has a higher dissolved-solids concentration. This mineralization reflects water quality observed in drainage from two surface coal mining operations in Blue Creek basin. One small mine was abandoned just prior to this project, the other opened early in 1978 .

\section{Nutrients}

Nutrients in the form of various nitrogen and phosphorus compounds are essential for the growth of aquatic vegetation. Total nitrogen concentrations ranged from 0.09 to $0.64 \mathrm{mg} / \mathrm{L}$ and total phosphorus concentrations ranged from 0.00 to $0.02 \mathrm{mg} / \mathrm{L}$. These levels are indicative of streams relatively free of organic pollution. Nutrients in streams studied are largely derived from natural sources such as precipitation (table 7) and soils enriched by the decomposition of organic matter. Concentrations of nitrite-nitrogen $\left(\mathrm{NO}_{2}-\mathrm{N}\right)$, nitrate-nitrogen $\left(\mathrm{NO}_{3}-\mathrm{N}\right)$, and nitrogen-nitrate $\left(\mathrm{NO}_{3}\right)$ at all sites were well below the recommended limits for drinking water standards (U.S. Environmental Protection Agency, 1977).

\section{Trace Elements}

Water collected from all sites was analyzed to determine trace element concentrations (tables 8 through 14). The highest concentrations obtained were for aluminum, iron, and manganese. Generally, the highest concentrations occurred during high flow and the lowest during low flow.

Trace element concentrations, with the exception of those for iron and manganese, were well below the maximum concentration limits recommended by the U.S. Environmental Protection Agency (1977). Dissolved manganese concentrations frequently exceeded the recommended limit (50 ug/L) at sites 3 and 7 during highflow periods. At these same sites, the recommended limit for dissolved iron $(300 \mathrm{ug} / \mathrm{L})$ was exceeded only once. Water in streams in Yellow Creek basin (sites $5,6,7)$, underlain chiefly by the Coker Formation, generally contained the highest concentrations of dissolved iron.

Total recoverable concentrations of trace elements in a water-suspended sediment solution and recoverable concentrations from stream bottoms (tables 8 through 14) indicate that only a very small fraction of available aluminum, iron, and manganese are in solution. Much greater concentrations are adsorbed on solid materials in the streams. In Bear and Blue Creek basins in the Pottsville area (sites 1, 2, and 3) the average total recoverable concentrations in suspension of aluminum, iron, and manganese were about 29, 28, and 3 times greater than the respective dissolved concentrations of those constituents. In Yellow Creek basin in the Coker area (sites 5, 6, and 7), the average total recoverable concentrations in suspension of aluminum, iron, and manganese were about 7, 13, and 2 times greater than the respective dissolved concentrations of those constituents. At all other sites the dissolved, total recoverable in a water-suspended sediment solution, and recoverable concentrations in bottom material of most other trace elements varied slightly and generally were of the same magnitude. 
The hilly terrain with moderate to steep slopes in the study area produces rapid runoff with high erosion potential. The dense forest, however, reduces the influence of topography on erosion and accompanying sediment yields. The relations between suspended-sediment concentration and corresponding stream discharge for sites 1 through 7 are shown in figures 11 through 17 . The relations are useful for estimating sediment loads for given stream discharges.

Sediment samples at sites 1 and 7 were collected daily with automatic PS-69 samplers. Samples were collected manually during low and high flows to calibrate the automatic samplers and to obtain information for all sites through their full range of discharge. Sediment transported between sampler intake nozzles and the streambed was not sampled during the study.

Suspended-sediment concentrations at sites 1 and 7 varied from near zero during low flow to about $2,500 \mathrm{mg} / \mathrm{L}$ and $1,600 \mathrm{mg} / \mathrm{L}$, respectively, during high flow. The average annual sediment loads for sites 1 and 7 were about 2,900 $t$ and $600 t$, respectively. Suspended-sediment discharge data for sites 1 and 7 for the 1977 and 1978 water years are summarized in table 15. The larger sediment yield at site 1 probably is due to differences in basin topography. The topography in the outcrop of the Pottsville Formation is more rugged than the Coker Formation.

Suspended-sediment samples collected during high flow at sites 1,3 , and 7 were analyzed for particle size distribution. The results indicated a composition of 50 percent clay and silt, and 50 percent fine sand at sites 1 and 7 . The composition at site 3 was about 98 percent clay and silt, and 2 percent sand.

\section{BIOLOGY}

Biological sampling provides information on the environmental quality of a stream over a long period of time. The benthic invertebrate and periphytic diatom communities were used as long-term and short-term water quality indicators, respectively. Both communities are sensitive to water quality changes, with diatoms reflecting these changes by rapid shifts in species composition.

Biologic data in this report are restricted to the data collected April through September 1977. All findings are preliminary because of the limited study period.

\section{METHODS AND TECHNIQUES}

Benthic invertebrate samples were collected with a 210-micron-mesh bag Surber sampler. Samples from a total area of $1.11 \mathrm{~m}^{2}$ were collected monthly at each site using random stratified sampling. Periphyton samples were collected by scraping a $26 \mathrm{~cm}^{2}$ area of natural substrate and preserving the scrapings in 4 percent formalin. 
Baseline conditions of the biological communities and their structure are assessed largely with the use of descriptive statistics and indexes. Total and individual counts, generic richness and evenness, and a Shannon-Wiener diversity index (Southwood, 1976) were calculated for each sample.

The Shannon-Wiener diversity index used was

$$
H(G)=3.3219\left(\log _{10} \mathrm{~N}-1 / \mathrm{N} \quad \Sigma \mathrm{n}_{\mathrm{i}} \log _{10^{\mathrm{n}}} \mathrm{n}_{\mathrm{i}}\right)
$$

where $H(G)$ = diversity at generic level

$$
\begin{aligned}
\mathbf{n}_{\mathbf{i}} & =\text { the number of individuals in category } \mathbf{i} \\
\mathbf{i} & =\text { genus or other taxon } \\
\mathrm{N} & =\text { total number of individuals in the collection (sample) }
\end{aligned}
$$

$3.3219=$ conversion factor $\log _{10}$ to $\log _{2}$

Evenness was calculated using the formula

$$
J=\frac{H(G)}{H(G)} \max
$$

where $\mathrm{J}=$ evenness at generic level

$H(G)=$ generic diversity

$H$ (G) $\max =\log _{2}$ (number of genera in sample).

\section{ENVIRONMENT}

Biologic sampling was restricted to riffle areas. These erosional features are relatively stable and generally contain a dense and diverse biologic community. Riffle velocities at data collection sites ranged from 3 to $91 \mathrm{~cm} / \mathrm{s}$ and averaged $13 \mathrm{~cm} / \mathrm{s}$.

The size of the substrate differs between Pottsville and Coker riffles (table 16). Riffles in both geologic environments contain 90 to $160 \mathrm{~mm}$ platy rocks that cover sand, gravel, and silt particles. Rocks in Pottsville riffles have an average thickness of about $10 \mathrm{~mm}$ and those in Coker riffles have an average thickness of about $25 \mathrm{~mm}$. The Coker riffles have less gravel and more sand than the Pottsville riffles. Sand is a fairly unproductive substrate, whereas the larger rocks, especially those in the 45 to $90 \mathrm{~mm}$ size class (Lium, 1974), have higher densities of organisms.

All streams studied drain heavily wooded areas. Transported litter is important to riffle communities (Minshal1, 1967); leaves and other organic litter serve as food for many benthic invertebrates. Water quality, substrate size, and velocity are other principal factors affecting these communities, but all are 
Table 16.--Percent composition of bed material in streams, July 1978

[C and $P$ denote Coker and Pottsville riffles, respectively]

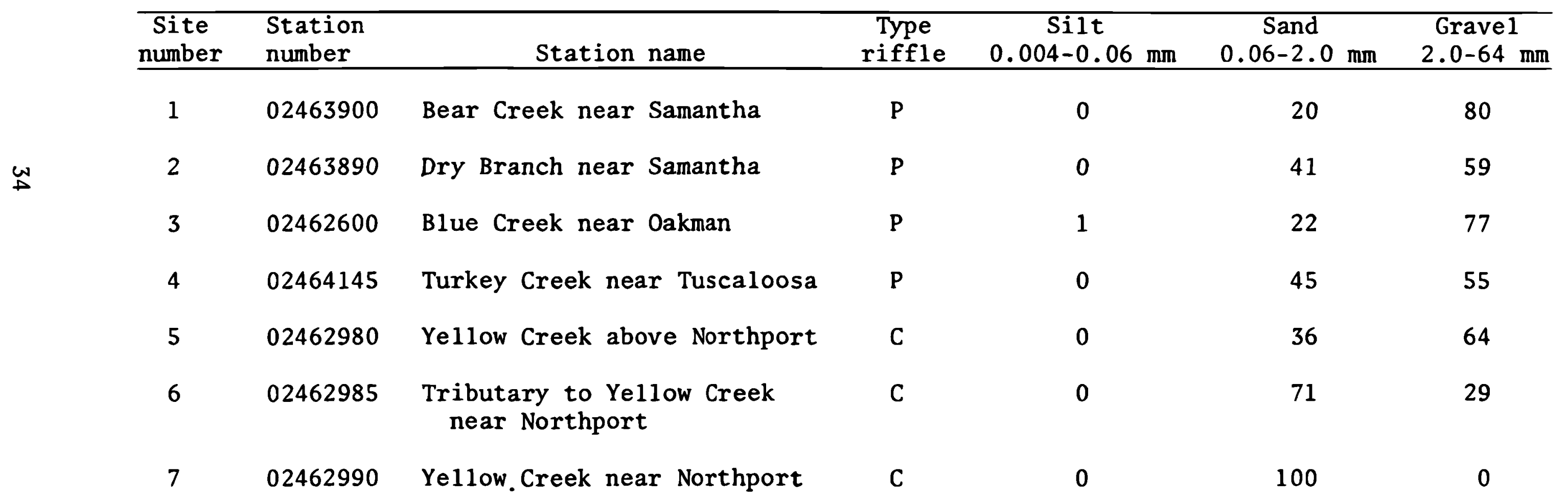


subordinate to leaf litter, the ultimate factor controlling the distribution and abundance of invertebrates in undisturbed streams.

The primary food source of the stream ecosystem is the periphytic diatom community which colonizes most substrates to some degree. Factors affecting the diatom communities are light intensity, water quality, carbon dioxide, flow regime, $\mathrm{pH}$, and nutrients.

\section{BENTHIC INVERTEBRATE COMMUNITY}

Riffles at the data collection sites (fig. 5) yielded more than 7,000 organisms. Approximately 98 percent of the fauna belongs to the Class Insecta. The taxonomic classification, distribution, and number of invertebrates are given in table 17. The percentage of each organism in the total collection and its percentage at Coker or Pottsville sites were also calculated.

A Shannon-Wiener diversity index was used to compare the compositions of benthic invertebrate communities at riffles in Coker and Pottsville basins. Separate measures were made of generic richness and evenness from the diversity index. Richness is expressed as the number of genera in a sample and evenness is an expression of the relative number of organisms in each genus in a community and the relationship of the numbers to each other. Evenness increases as the numbers become increasingly similar and is at a maximum when genera are equally represented.

Mean diversities for Coker and Pottsville riffles (table 18) were 3.46 and 3.00 , respectively. A diversity of 3 to 4 is indicative of an undisturbed stream (Wilhm, 1970). The Coker riffles have higher diversity, richness, and evenness. This is probably due to the more stable base flow of the Coker streams. For instance, base flow in a Coker stream is maintained (fig. 10) when a Pottsville stream approaches or equals zero (fig. 9). The effect of variations in base flow on generic diversity and richness is illustrated in figure 18. During the period of record, diversity and richness at Coker riffles (sites 6 and 7 on fig. 18) reached their maximum while diversity and richness of the Pottsville riffle at site 3 (fig. 18) reached their minimum as base flow reached zero.

\section{PERIPHYTIC DIATOM COMMUNITY}

A total of 98 species representing 25 genera were collected during the period of record (table 19). Only three species, Eunotia rostellata, Anomoeoneis serians, and Frustulia rhomboides, were abundant and constant in occurrence. Diatom communities with high diversities indicate undisturbed streams.

Mean values of diversity for the Pottsville and Coker riffles were 2.17 and 2.62 , respectively (table 20). Evenness values averaged $0.57 \pm 0.14$ for the Pottsville sites and $0.66 \pm 0.14$ for the Coker sites. The smaller diversity and evenness values of the Pottsville riffles are probably due, at least in part, to the same lack of base flow that affects the benthic invertebrate communities. 
Table 18.--Diversity, richness, evenness, and total number of organisms for benthic invertebrate communities, May-August 1977

\section{Coker Riffles}

\begin{tabular}{|c|c|c|c|c|c|}
\hline Parameter & $\begin{array}{c}\text { Number } \\
\text { of } \\
\text { samples }\end{array}$ & Mean & Minimum & Maximum & $\begin{array}{l}\text { Standard } \\
\text { deviation }\end{array}$ \\
\hline Diversity & 32 & 3.46 & 0.90 & 4.0 & 0.76 \\
\hline Richness & 32 & 22 & 3 & 40 & 9 \\
\hline Evenness & 32 & .82 & .52 & .98 & .10 \\
\hline \multirow[t]{2}{*}{ Total number } & 32 & 148 & 3 & 706 & 148 \\
\hline & \multicolumn{4}{|c|}{ Pottsville Riffles } & \\
\hline Parameter & $\begin{array}{c}\text { Number } \\
\text { of } \\
\text { samples }\end{array}$ & Mean & Minimum & Maximum & $\begin{array}{l}\text { Standard } \\
\text { deviation }\end{array}$ \\
\hline Diversity & 12 & 3.00 & 1.8 & 3.6 & 0.65 \\
\hline Richness & 12 & 18 & 9 & 27 & 7 \\
\hline Evenness & 12 & .77 & .59 & .95 & .12 \\
\hline Total number & 12 & 156 & 36 & 407 & 117 \\
\hline
\end{tabular}



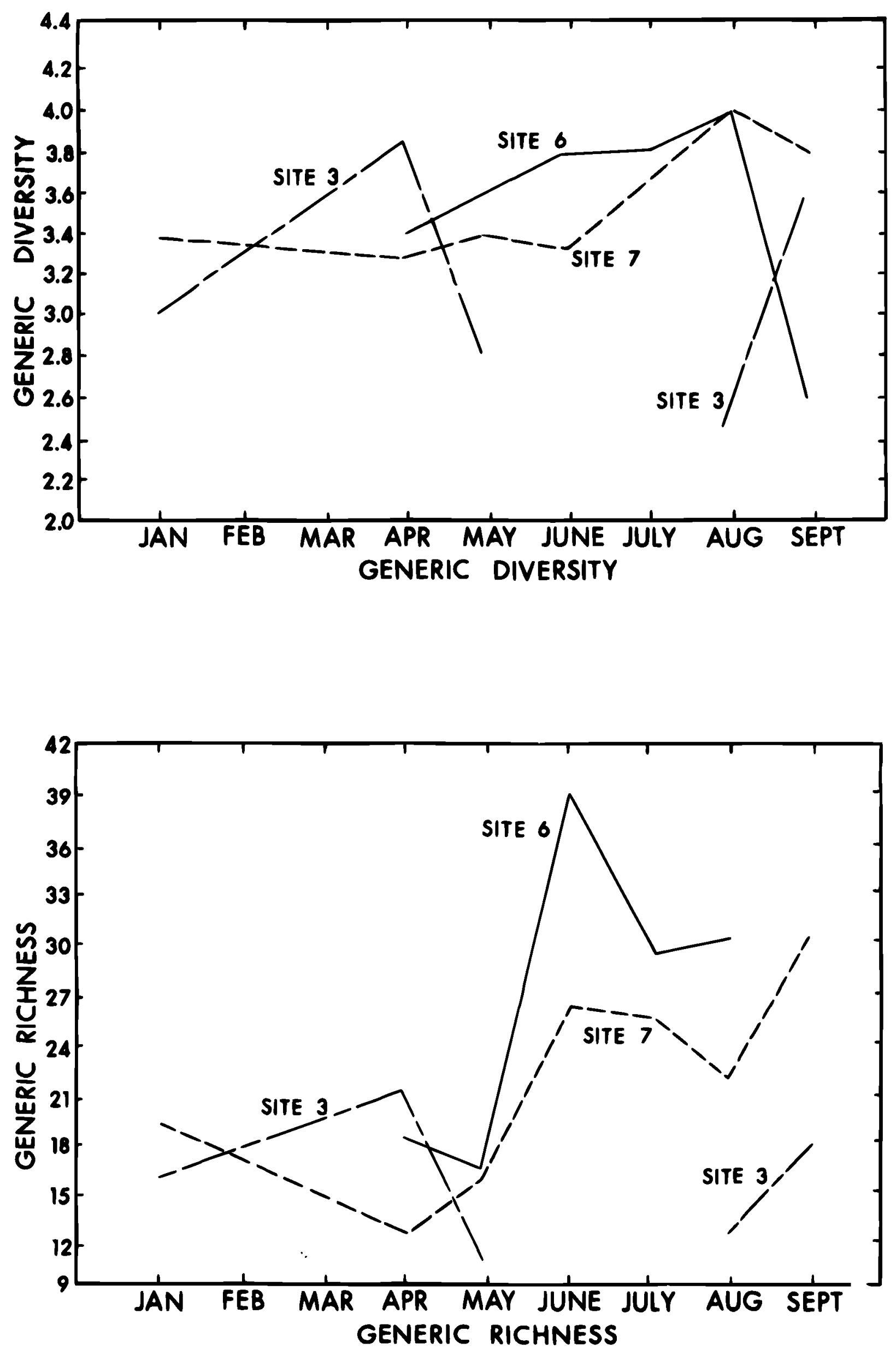

Figure 18.--Variations of generic diversity and richness at selected riffles, 1977 . 
Table 20.--Diversity, richness, evenness, and total number of organisms for periphytic diatom communities,

May-August 1977

\section{Coker Riffles}

\begin{tabular}{lcrccc}
\hline & $\begin{array}{c}\text { Number } \\
\text { of } \\
\text { samples }\end{array}$ & Mean & Minimum & Maximum & $\begin{array}{c}\text { Standard } \\
\text { deviation }\end{array}$ \\
\hline Diversity & 18 & 2.62 & 1.21 & 3.47 & 0.64 \\
Richness & 18 & 16.06 & 9 & 26 & 4.43 \\
Evenness & 18 & .66 & .33 & .81 & .14 \\
$\begin{array}{l}\text { Total number } \\
\text { of cells/cm }\end{array}$ & 18 & 222,000 & 3400 & $2,500,000$ & 578,000 \\
\hline
\end{tabular}

\section{Pottsville Riffles}

\begin{tabular}{lccccc}
\hline & $\begin{array}{c}\text { Number } \\
\text { of } \\
\text { samples }\end{array}$ & Mean & Minimum & Maximum & $\begin{array}{c}\text { Standard } \\
\text { deviation }\end{array}$ \\
\hline Parameter & 13 & 2.17 & 1.40 & 3.65 & 0.64 \\
Diversity & 13 & 15.23 & 5 & 27 & 5.37 \\
Richness & 13 & .57 & .36 & .84 & .14 \\
Evenness & 13 & 382,000 & 240 & $1,100,000$ & 366,000 \\
$\begin{array}{l}\text { Total number } \\
\text { of cells/cm }\end{array}$ & & & & & \\
\hline
\end{tabular}


Hydrologic data are being collected in four basins in the Warrior coal field to provide baseline information to aid in determining the effect mining will have on water resources. This progress report contains findings based on information collected during the first 2 years of the study.

The largely undisturbed study basins are in two geologic environments. Bear and Blue Creek basins are predominantly underlain by the Pottsville Formation, which consists mainly of alternating beds of shale, sandstone, and siltstone interbedded with conglomerate, underclay, and coal. Turkey and Yellow Creek basins are predominantly in the outcrop of the Coker Formation which overlies the Pottsville Formation. The Coker consists of unconsolidated beds of sand, clay, and gravel.

Variations in the geology of the basins result in large differences in their hydrology. Rocks in the Pottsville Formation are relatively impermeable, whereas those in the Coker Formation are permeable. Well yields from the Pottsville are generally less than $0.3 \mathrm{~L} / \mathrm{s}$, while those from the Coker are as much as $6.4 \mathrm{~L} / \mathrm{s}$.

Ground water in the Pottsville is generally acidic and moderately hard to very hard. Dissolved solids concentrations ranged from 176 to $268 \mathrm{mg} / \mathrm{L}$. Water in the Coker Formation is less mineralized and more acidic than water in the Pottsville. The water is soft and generally has dissolved solids concentrations less than $20 \mathrm{mg} / \mathrm{L}$.

Streamflow reflects seasonal precipitation with storm runoff characterized by sharply concentrated peak flows of short duration that rapidly recede to low-flow conditions. Streams draining Bear and Blue Creek basins frequently go dry, whereas low flows in Turkey and Yellow Creek basins are well sustained by ground-water discharge from the Coker Formation.

Surface water is generally acidic, soft, and low in dissolved solids. Water in streams draining basins underlain chiefly by the Pottsville Formation is slightly more mineralized than that in streams draining basins underlain chiefly by the Coker Formation. Water in streams draining Bear and Blue Creek basins during low flow is far less mineralized than ground water in the Pottsville Formation. This indicates that the ground-water contribution from the Pottsville is derived mainly from recent recharge. In basins underlain chiefly by the Coker Formation, the quality of water in streans and in the formation is very similar.

Annual suspended-sediment yields at outflow sites of Bear and Yellow Creek basins averaged $75 \mathrm{t} / \mathrm{km}^{2}$ and $28 \mathrm{t} / \mathrm{km}^{2}$, respectively.

Limited biologic sampling of benthic invertebrate and periphytic diatom communities in riffles shows that the streams monitored support a large variety of species. 
Culbertson, W. C., 1964, Geology and coal resources of the coal-bearing rocks of Alabama: U.S. Geological Survey Bulletin H82-B, 79 p.

Durfor, C. N., and Becker, E., 1964, Public water supplies of the 100 largest cities in the United States, 1962: U.S. Geological Survey Water-Supply Paper $1812,364 \mathrm{p}$

Frentz, H. J., and Lynott, W. P., 1978, Baseline study of the climate and air quality of Fayette, Walker, Jefferson, and Tuscaloosa Counties, Alabama: Science Applications, Inc., Report to the Bureau of Land Management (contract No. 1-022-03-080-62), 274 p.

Hayes, Eugene C., 1978, 7-day low flows and flow duration of Alabama streams through 1973: Alabama Geological Survey Bulletin 113, 163 p.

Lium, B. W., 1974, Some aspects of aquatic insect populations of pools and riffles in gravel bed streams in western United States: U.S. Geological Survey, Journal of Research, v. 2, p. 379-384.

McCalley, Henry, 1900, Report on the Warrior coal basin: Alabama Geological Survey Special Report 10, 327 p.

Metzger, W. J., 1965, Pennsylvanian stratigraphy of the Warrior basin, Alabama: Alabama Geological Survey Circular 30, 80 p.

Miller, J. D., Jr., 1958, Ground water in the vicinity of Bryce State Hospital, Tuscaloosa County, Alabama: Alabama Geological Survey Information Series 12, $30 \mathrm{p}$.

Miller, J. D., Jr., and Causey, L. V., 1958, Geology and ground-water resources of Tuscaloosa County, Alabama: Alabama Geological Survey Information Series $14,71 \mathrm{p}$.

Minshal1, G. W., 1967, Role of allochthanous detritus in the trophic structure of a woodland springbrook community: Ecology, v. 48, p. 139-149.

Paulson, Q. F., Miller, J. D., and urennen, C. W., 1962, Ground-water resources and geology of Tuscaloosa County, Alabama: Alabama Geological Survey County Report 6, $97 \mathrm{p}$.

Peirce, L. B., 1959, Surface-water resources and hydrology of west-central Alabama: Alabama Geological Survey Special Report 24, 236 p.

1962, Surface water in Tuscaloosa County, Alabama: Alabama Geological Survey County Report 9, 89 p. 
Peirce, L. B., 1967, 7-day low flows and flow duration of Alabama streams: Alabama Geological Survey Bulletin 87, Part A, 114 p.

Searcy, J. K., 1959, Flow-duration curves, manual of Hydrology: Part 2, low-flow techniques: U.S. Geological Survey Water-Supply Paper 1542-A, 33 p.

Semmes, D. R., 1929, Oil and gas in Alabama: Alabama Geological Survey Special Report 15, $400 \mathrm{p}$.

Shotts, R. Q., 1967, The Utley coal bed in the western Warrior field: Alabama Academy of Science Journal 38, p. 202-214.

Southwood, T. R. E., 1976, Ecological methods: London, Chapman and Ha11, 391 p.

U.S. Environmental Protection Agency, 1977, National interim primary drinking water regulations: Environmental Protection Agency Report 570/9-76-003, $159 \mathrm{p}$.

U.S. Geological Survey, 1978, Water resources data for Alabama, water year 1977: U.S. Geological Survey Water-Data Report, AL 77-1, 459 p.

1979, Water resources data for Alabama, water year 1978: U.S. Geological Survey Water-Data Report AL 78-1, 568 p.

Wahl, K. D., 1965, Ground water in the vicinity of Bryce State Hospital, Negro Colony, Tuscaloosa County, Alabama: Alabama Geological Survey Circular 25, $38 \mathrm{p}$.

Wilhm, J. L., 1970, Range of diversity index in benthic macroinvertebrate populations: Water Pollution Control Federation Journal, v. 42, no. 5, pt. 2, p. 221-224. 
Table 2.--Records of wells and springs in and near study areas in Tuscaloosa County

(Well numbers correspond with those on plate 4)

Depth: Reported depths given in meters; measured depths in meters and tenths.
Water level: Reported levels given in meters; measured levels given in meters and tenths.

Water-bearing unit: Ppv, Pottsville Formation; Kck, Coker Formation. Use of water: D, domestic; N, none; PS, public supply; S, stock.

Altitude: Altitudes determined by aneroid barometer.

\begin{tabular}{|c|c|c|c|c|c|c|c|c|c|c|c|c|c|}
\hline \multirow[b]{2}{*}{$\begin{array}{c}\text { Field } \\
\text { well. } \\
\text { number }\end{array}$} & \multirow[b]{2}{*}{ Owner } & \multirow[b]{2}{*}{$\begin{array}{r}\text { Year } \\
\text { com- } \\
\text { pleted }\end{array}$} & \multirow[b]{2}{*}{$\begin{array}{c}\text { Depth } \\
\text { of well } \\
\text { (meters) } \\
\end{array}$} & \multirow[b]{2}{*}{$\begin{array}{c}\text { Diame- } \\
\text { ter of } \\
\text { well } \\
\text { (milli- } \\
\text { meters) }\end{array}$} & \multirow[b]{2}{*}{$\begin{array}{c}\text { Water } \\
\text { bearing } \\
\text { unit }\end{array}$} & \multirow[b]{2}{*}{$\begin{array}{l}\text { Altitude } \\
\text { of land } \\
\text { surface } \\
\text { (meters- } \\
\text { NGVD of } \\
1929 \text { ) }\end{array}$} & \multicolumn{2}{|c|}{ Water level } & \multirow[b]{2}{*}{$\begin{array}{l}\text { Use } \\
\text { of } \\
\text { water }\end{array}$} & \multicolumn{4}{|c|}{ Field determinations } \\
\hline & & & & & & & $\begin{array}{c}\text { Below } \\
\text { land } \\
\text { surface } \\
\text { (meters) }\end{array}$ & $\begin{array}{c}\text { Date of } \\
\text { measure- } \\
\text { ment }\end{array}$ & & Date & $\begin{array}{l}\text { Specific } \\
\text { conduct- } \\
\text { ance } \\
\text { (micro- } \\
\text { mhos at } \\
25^{\circ} \mathrm{C} \text { ) }\end{array}$ & $\mathrm{pH}$ & $\begin{array}{l}\text { Tem- } \\
\text { per- } \\
\text { ature } \\
\left({ }^{\circ} \mathrm{C}\right) \\
\end{array}$ \\
\hline 1 & D. Cunningham & 1914 & 20.7 & 762 & Kck & 144 & 19.2 & $2-2-77$ & D & $2-2-77$ & 46 & 4.9 & 14.5 \\
\hline 2 & D. Cunningham & 1976 & 28.9 & 51 & Ppv & 126 & Flowing & $2-2-77$ & $\mathrm{~N}$ & $2-2-77$ & 400 & 7.5 & 16.5 \\
\hline 3 & -- Coleburn & 1898 & 6.1 & 914 & Kck & 148 & 5.2 & $2-2-77$ & $\mathrm{~N}$ & -....... & -....... & -- &.-- \\
\hline 4 & -- Boyd & ----- & 23.7 & 914 & Kck & 168 & 23.2 & $2-2-77$ & D & $2-2-77$ & - & --- & 15.0 \\
\hline 5 & C. Cunningham & 1972 & 2.7 & 914 & Kck & 132 & 1.0 & $2-3-77$ & D & $2-3-77$ & 17 & 7.6 & 8.5 \\
\hline * 6 & M. Howe11 & $\ldots$ & 30 & 102 & Kck & 176 & 26.9 & $2-3-77$ & D & $2-3-77$ & 13 & 5.3 & 15.5 \\
\hline * 7 & M. Barger & ---- & Spring & --- & Kck & 140 & $\ldots$ & $2-3-77$ & D & $2-3-77$ & 25 & 5.3 & 5.0 \\
\hline 8 & M. Barger & -....- & Spring &.- & Kck & 133 & $\ldots$ & $2-3-77$ & D & $2-3-77$ & 20 & 5.6 & 10.0 \\
\hline 9 & M. Barger & ---- & Spring & -- & Kck & 128 &.-- & $3-16-77$ & D & $3-16-77$ & 20 & 5.6 & 15.5 \\
\hline 10 & M. Barger & 1957 & $15.2^{\circ}$ & 152 & -- & 110 & 2.3 & $3-16-77$ & $\mathrm{~N}$ & - & $\ldots$ &.- &..- \\
\hline 11 & D. Cunningham & $\cdots$ & Spring & -- & Kck & 124 & $\ldots$ & $3-16-77$ & $\mathbf{N}$ & $3-16-77$ & 21 & 6.1 & 15.0 \\
\hline 12 & R. Sorell & ---- & $\ldots$ & 762 & Kck & 138 & 5.0 & $3-16-77$ & D & $3-16-77$ & $100 ?$ & 5.7 & 14.5 \\
\hline 13 & B. Vaughn & $\cdots-$ & Spring &.- & Kck & 128 & $\ldots$ & $3-17-77$ & D & $3-17-77$ & 41 & 4.9 & 13.5 \\
\hline 14 & E. Pierce & ----- & 14.9 & 152 & Ppv & 116 & 9.4 & $3-17-77$ & D & $3-17-77$ & 220 & 6.8 & 14.5 \\
\hline 15 & -- Hallman & 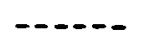 & 5.5 & 914 & Kck & 138 & 2.2 & $3-17-77$ & D & $3-17-77$ & 21 & 6.0 & 14.5 \\
\hline 16 & J. Maddox & -....- & 14.8 & 914 & Kck & 162 & 13.6 & $3-17-77$ & D & $3-17-77$ & 18 & 5.6 & 15.5 \\
\hline 17 & P. Hinton & 1968 & 1.8 & 914 & Kck & 142 & 1.2 & $8-2-77$ & D & $3-17-77$ & 15 & 5.5 & 12.5 \\
\hline 18 & W. Cunningham & $-\ldots$ & Spring & -- & Kck & 141 & $\ldots$ & $3-17-78$ & D & $3-17-77$ & 14 & 5.6 & 13.5 \\
\hline 19 & $\begin{array}{l}\text { Yellow Creek } \\
\text { Baptist Church }\end{array}$ & ----- & $23.5^{\circ}$ & 102 & Kck & 161 & 23.1 & $3-18-78$ & PS & $3-18-77$ & 37 & 5.4 & 16.5 \\
\hline 20 & B. Powell & ------ & ------ & 102 & Kck & 155 & --- & $3-18-78$ & D & $3-18-77$ & 16 & 5.4 & 16.5 \\
\hline
\end{tabular}


Table 2.--Records of wells and springs in and near study areas in Tuscaloosa County--Continued

\begin{tabular}{|c|c|c|c|c|c|c|c|c|c|c|c|c|c|}
\hline $\begin{array}{c}\text { Field } \\
\text { well } \\
\text { number }\end{array}$ & Owner & $\begin{array}{c}\text { Year } \\
\text { com- } \\
\text { pleted } \\
\end{array}$ & $\begin{array}{l}\text { Depth } \\
\text { of well } \\
\text { (meters) }\end{array}$ & $\begin{array}{l}\text { Diame- } \\
\text { ter of } \\
\text { well } \\
\text { (milli- } \\
\text { meters) }\end{array}$ & $\begin{array}{c}\text { Water } \\
\text { bearing } \\
\text { unit }\end{array}$ & $\begin{array}{l}\text { Altitude } \\
\text { of land } \\
\text { surface } \\
\text { (meters- } \\
\text { NGVD of } \\
\text { 1929) }\end{array}$ & $\begin{array}{c}\text { Below } \\
\text { land } \\
\text { surface } \\
\text { (meters) }\end{array}$ & $\begin{array}{c}\text { Date of } \\
\text { measure- } \\
\text { ment }\end{array}$ & $\begin{array}{c}\text { Use } \\
\text { of } \\
\text { water }\end{array}$ & Date & $\begin{array}{l}1 \text { d determi } \\
\text { Specific } \\
\text { conduct- } \\
\text { ance } \\
\text { (micro- } \\
\text { mhos at } \\
25^{\circ} \mathrm{C} \text { ) }\end{array}$ & ations & $\begin{array}{l}\text { Tem- } \\
\text { per- } \\
\text { ature } \\
\left({ }^{\circ} \mathrm{C}\right) \\
\end{array}$ \\
\hline 21 & H. Dunn & -...-- & Spring & 914 & Kck & 134 & $-\ldots$ & $3-18-78$ & D. & $3-18-77$ & 13 & 5.4 & 13.5 \\
\hline 22 & D. Cunningham & 1946 & 18.3 & 762 & Kck & 155 & 17.1 & $7-14-54$ & D & $3-18-77$ & 23 & 5.8 & 17.5 \\
\hline 23 & D. Cunningham & 1933 & 19 & 711 & Kck & 154 & $-\cdots$ & $3-18-77$ & D & $3-18-77$ & 35 & 5.6 & 17.5 \\
\hline 24 & D. Cunningham & $\ldots$ & Spring & 711 & Kck & 134 & --- & $3-18-77$ & D & $3-18-77$ & 32 & 5.9 & 17.0 \\
\hline 25 & A. Duncan & ----- & 16 & 762 & Kck & 148 & 12 & $3-18-77$ & D & $3-18-77$ & 45. & 6.0 & 17.5 \\
\hline 26 & D. Cunningham & -..-- & Spring & --- & Kck & 139 & --- & $4-13-77$ & D & $4-13-77$ & 30 & 5.1 & 14.5 \\
\hline 27 & Z. Marcum & -....- & 16 & 610 & Kck & 154 & 13.6 & $4-13-77$ & D & $4-13-77$ & 205? & 6.7 & 16.0 \\
\hline 28 & 0 . Grammer & -...... & Spring & 762 & Kck & 148 & $\ldots$ & $4-13-77$ & D & $4-13-77$ & 25 & 4.9 & 17.0 \\
\hline 29 & J. Turner & 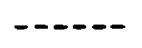 & Spring & 914 & Kck & 136 & $-\cdots$ & $4-13-77$ & D & $4-13-77$ & 13 & 5.3 & 16.0 \\
\hline 30 & E. Coleburn & 1975 & Spring & 762 & Kck & 134 & --- & $4-13-77$ & D & $4-13-77$ & 14 & 5.5 & 15.0 \\
\hline 31 & C. Watson & $-\cdots$ & 19 & 102 & Kck & 154 & 13 & $4-13-77$ & D & $4-13-77$ & 12 & 5.0 & 16.5 \\
\hline * 32 & F. Cunningham & ---.-- & 13.7 & 762 & Kck & 151 & 12.2 & $4-14-77$ & D & $4-14-77$ & 61 & 6.2 & 17.0 \\
\hline 33 & R. Jenkins & ---- & Spring & 762 & Kck & 155 & $\cdots-$ & $4-14-77$ & D & $4-14-77$ & 19 & 5.8 & 16.0 \\
\hline 34 & R. Jenkins & -..... & 21 & 152 & Kck & 148 & $\ldots$ & $4-14-77$ & D & $4-14-77$ & 18 & 5.1 & 17.0 \\
\hline 35 & J. Lyster & $\cdots$ & ---- & 152 & Ppv & 88 & --- & $4-14-77$ & D & $4-14-77$ & 310 & 7.1 & 16.5 \\
\hline 36 & B. Dunn & 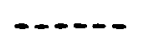 & 40 & 152 & Ppv & 136 & --- & $4-14-77$ & D & $4-14-77$ & 163 & 6.9 & 20.0 \\
\hline 37 & $\begin{array}{l}\text { Gulf States Paper } \\
\text { Corp. }\end{array}$ & -...-- & Spring & 762 & Kck & 132 & $-\cdots$ & $4-14-77$ & D & $4-14-77$ & 14 & 5.3 & 15.0 \\
\hline 38 & W. Bigham & -...- & Spring & 762 & Kck & 133 & $-\ldots$ & $4-14-77$ & D & $4-14-77$ & 12 & 5.6 & 15.0 \\
\hline 39 & R. Lollar & 1942 & 8.2 & 610 & Kck & 161 & 5.2 & $4-20-77$ & D & $4-20-77$ & 96 & 6.9 & 14.5 \\
\hline 40 & L. Maddox & $-\cdots-$ & 16.8 & 914 & Kck & 165 & 14.8 & $4-19-77$ & D & $4-19-77$ & 45 & 5.6 & 17.5 \\
\hline 41 & L. Maddox & ------ & Spring & 762 & Kck & 152 & $-\cdots$ & $4-19-77$ & D & $4-19-77$ & 36 & 5.1 & 15.0 \\
\hline 42 & J. McPearson & ----- & Spring & 610 & Kck & 152 & $-\ldots$ & $4-19-77$ & D & $4-19-77$ & 27 & 5.0 & 15.0 \\
\hline 43 & J. McPearson & -..... & 18 & 711 & Kck & 169 & 15.8 & $4-19-77$ & $\mathrm{~N}$ & $-\ldots$ & -- & -- & --- \\
\hline 44 & G. McPearson & $\cdots$ & 17.6 & 610 & Kck & 167 & 12.3 & $8-1-77$ & D & $4-20-77$ & 182 & 7.5 & 16.5 \\
\hline 45 & G. McPearson & -..-- & Spring & -- & Kck & 147 & --- & $4-20-77$ & D & $4-20-77$ & 34 & 5.6 & 14.5 \\
\hline 46 & J.' Lollar & $-\cdots$ & 27 & -- & Kck & 155 & --- & $4-20-77$ & $\mathrm{~N}$ & $-\ldots$ & -- & --- & --- \\
\hline 47 & J. Lo1lar & ----- & 97 & 102 & Ppv & 160 & $\cdots$ & $4-20-77$ & $\mathbf{N}$ & --- & --- & --- & --- \\
\hline 48 & $\begin{array}{l}\text { Pineywoods Baptist } \\
\text { Church }\end{array}$ & --- & $-\cdots-$ & 152 & Kck & 166 & $\cdots$ & $4-20-77$ & $\mathbf{N}$ & ---- & --- & -- & --- \\
\hline 49 & W. Wallace & $-\ldots$ & Spring & -- & Kck & 160 & --- & $4-20-77$ & D & $4-20-77$ & 14 & 5.9 & 15.0 \\
\hline
\end{tabular}


Table 2.--Records of wells and springs in and near study areas in Tuscaloosa County--Continued

\begin{tabular}{|c|c|c|c|c|c|c|c|c|c|c|c|c|c|}
\hline \multirow[b]{2}{*}{$\begin{array}{c}\text { Field } \\
\text { well } \\
\text { number }\end{array}$} & \multirow[b]{2}{*}{ Owner } & \multirow[b]{2}{*}{$\begin{array}{c}\text { Year } \\
\text { com- } \\
\text { pleted } \\
\end{array}$} & \multirow[b]{2}{*}{$\begin{array}{c}\text { Depth } \\
\text { of well } \\
\text { (meters) }\end{array}$} & \multirow[b]{2}{*}{$\begin{array}{l}\text { Diame- } \\
\text { ter of } \\
\text { well } \\
\text { (milli- } \\
\text { meters) }\end{array}$} & \multirow[b]{2}{*}{$\begin{array}{c}\text { Water } \\
\text { bearing } \\
\text { unit }\end{array}$} & \multirow[b]{2}{*}{$\begin{array}{l}\text { Altitude } \\
\text { of land } \\
\text { surface } \\
\text { (meters- } \\
\text { NGVD of } \\
1929 \text { ) }\end{array}$} & \multicolumn{2}{|c|}{ Water level } & \multirow[b]{2}{*}{$\begin{array}{l}\text { Use } \\
\text { of } \\
\text { water }\end{array}$} & \multicolumn{4}{|c|}{ Field determinations } \\
\hline & & & & & & & $\begin{array}{c}\text { Below } \\
\text { land } \\
\text { surface } \\
\text { (meters) }\end{array}$ & $\begin{array}{c}\text { Date of } \\
\text { measure- } \\
\text { ment }\end{array}$ & & Date & $\begin{array}{l}\text { Specific } \\
\text { conduct- } \\
\text { ance } \\
\text { (micro- } \\
\text { mhos at } \\
25^{\circ} \mathrm{C} \text { ) } \\
\end{array}$ & $\mathrm{pH}$ & $\begin{array}{l}\text { Tem- } \\
\text { per- } \\
\text { ature } \\
\left({ }^{\circ} \mathrm{C}\right) \\
\end{array}$ \\
\hline 50 & C. Zeanah & 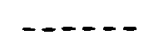 & 18.6 & 102 & Ppv & 168 & 7.9 & $4-21-77$ & $\mathbf{N}$ & $4-21-77$ & 265 & 6.9 & 17.0 \\
\hline 51 & C. Zeanah & $\ldots .$. & 36 & 102 & Ppv & 168 & 15 & $4-21-77$ & $\mathrm{D}$ & $4-21-77$ & 225 & 6.9 & 17.5 \\
\hline 52 & B. Clements & $\ldots$. & Spring & -.. & Kck & 167 & ...- & $5-18-77$ & D & $5-18-77$ & 18 & 5.1 & 15.5 \\
\hline$\star 53$ & W. Baughman & 1976 & 56 & 152 & Ppv & 136 & 9 & $5-18-77$ & $D, S$ & $5-18-77$ & 250 & 6.9 & 19.5 \\
\hline 54 & W. Baughman & 1953 & 50 & 152 & Ppv & 143 & 9 & $5-18-77$ & D & $5-18-77$ & 122 & 6.2 & 19.5 \\
\hline * 55 & D. Barnet & -...- & 16 & 152 & Ppv & 197 & 12.7 & $5-31-77$ & D & $5-31-77$ & 350 & 6.9 & 21.0 \\
\hline 56 & Irvin Realty & -.... & 27.2 & 152 & Ppv & 200 & 21.1 & $5-31-77$ & $\mathrm{~N}$ & $5-31-77$ & 138 & -.. & 17.5 \\
\hline 57 & Irvin Realty & $\ldots$. & 46.2 & 152 & $\mathrm{Ppv}$ & 200 & 25.0 & $5-31-77$ & $\mathrm{~N}$ & $5-31-77$ & 200 & 6.7 & 17.0 \\
\hline 58 & Irvin Realty & 1975 & 9.6 & 914 & Ppv & 195 & 4.6 & $5-31-77$ & $\mathbf{N}$ & $5-31-77$ & 33 & -.. & 19.5 \\
\hline 59 & L. Bagwell & 1950 & 19 & 152 & Ppv & 175 & 8 & $6-1-77$ & $D$ & $6-1-77$ & 255 & 6.8 & 18.5 \\
\hline 60 & L. Bagwell & 1928 & 12 & 152 & Ppv & 175 & 8 & $6-1-77$ & $\mathrm{~N}$ & $-\ldots$ & $\ldots$ & --- & $-\ldots$ \\
\hline 61 & E. Long & -.... & 27 & 152 & Ppv & 150 & 14 & $6-1-77$ & D & $6-1-77$ & 340 & 7.3 & 19.5 \\
\hline 62 & J. Bagwell & -..... & 28 & 152 & Ppv & 150 & 14 & $6-1-77$ & D & $6-1-77$ & 315 & 6.8 & 18.0 \\
\hline 63 & $\mathrm{~J}$. Bagwell & 1970 & 100 & 152 & Ppv & 142 & 22 & $6-1-77$ & $\mathbf{N}$ & 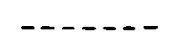 & $\ldots$ & --- & --- \\
\hline 64 & J. Bagwell & ---- & 64 & 152 & Ppv & 150 & 10.1 & $6-1-77$ & $\mathrm{~N}$ & -.... & -- & -- & -..- \\
\hline 65 & J. Bolton & -...- & 30 & 152 & Ppv & 160 & 24 & $6-1-77$ & D & $6-1-77$ & 415 & 7.1 & 18.5 \\
\hline 66 & J. Bolton & -...- & 17 & 152 & Ppv & 160 & 10.7 & $6-1-77$ & D & $6-1-77$ & 422 & 6.9 & 20.0 \\
\hline 67 & J. Baker & -..-- & 87 & 152 & Ppv & 199 & 35.6 & $6-2-77$ & D & $6-2-77$ & 340 & 7.5 & 17.5 \\
\hline 68 & J. Baker & 1917 & 30.0 & 152 & Ppv & 201 & 26.2 & $6-6-77$ & $\mathrm{~N}$ & $6-6-77$ & 270 & 7.3 & 17.5 \\
\hline 69 & J. Baker & 1917 & 30 & 152 & Ppv & 197 & 26 & $6-6-77$ & $\mathbf{N}$ & - - - &.- & --- & --- \\
\hline 70 & W. Baker & ---- & 57 & 102 & Ppv & 201 & --- & $6-6-77$ & D & - & -- & -- & --- \\
\hline 71 & W. Baker & -..... & 34.0 & 152 & Ppv & 201 & 20.2 & $6-6-77$ & $\mathrm{~N}$ & $6-6-77$ & 126 & 7.0 & 17.5 \\
\hline 72 & -- Blankenship & $-\ldots$ & -....- & 152 & Ppv & 162 & 9.0 & $6-6-77$ & D & $--\ldots$ & -- & -- & --- \\
\hline 73 & N. Armstrong & -.... & 64.0 & 152 & Ppv & 166 & 11 & $6-6-77$ & $D$ & $6-6-77$ & 196 & 7.1 & 18.0 \\
\hline 74 & N. Armstrong & ...... & -.... & 152 & Ppv & 149 & -... & $6-6-77$ & D & $6-6-77$ & 126 & -- & 18.5 \\
\hline 75 & B. Miller & -.-- - & 10.6 & 152 & $\mathrm{Ppv}$ & 144 & 8.3 & $6-7-77$ & D & $6-7-77$ & 290 & 7.1 & 18.0 \\
\hline 76 & B. Miller & 1975 & 21.6 & 152 & Ppv & 145 & 8.6 & $6-7-77$ & $\mathrm{~N}$ & - & --- & -. & $-\cdots$ \\
\hline 77 & J. Miller & 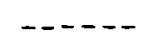 & 29 & 152 & Ppv & 149 & $\cdots$ & $6-7-77$ & D & $6-7-77$ & 440 & -- & 18.5 \\
\hline 78 & R. Swindle & $\ldots . .$. & 9.8 & 152 & Ppv & 148 & $-\ldots$ & $6-7-77$ & D & $6-7-77$ & 182 & 6.8 & 18.0 \\
\hline 79 & E. Evans & -.... & 8.3 & 152 & Ppv & 140 & 3.9 & $6-8-77$ & D & $6-8-77$ & 245 & 6.7 & 17.0 \\
\hline
\end{tabular}


Table 2.--Records of wells and springs in and near study areas in Tuscaloosa County--Continued

\begin{tabular}{|c|c|c|c|c|c|c|c|c|c|c|c|c|c|}
\hline \multirow[b]{2}{*}{$\begin{array}{c}\text { Field } \\
\text { well } \\
\text { number }\end{array}$} & \multirow[b]{2}{*}{ Owner } & \multirow[b]{2}{*}{$\begin{array}{c}\text { Year } \\
\text { com- } \\
\text { pleted }\end{array}$} & \multirow[b]{2}{*}{$\begin{array}{c}\text { Depth } \\
\text { of well } \\
\text { (meters) }\end{array}$} & \multirow[b]{2}{*}{$\begin{array}{l}\text { Diame- } \\
\text { ter of } \\
\text { well } \\
\text { (milli- } \\
\text { meters) }\end{array}$} & \multirow[b]{2}{*}{$\begin{array}{c}\text { Water } \\
\text { bearing } \\
\text { unit }\end{array}$} & \multirow[b]{2}{*}{$\begin{array}{l}\text { Altitude } \\
\text { of land } \\
\text { surface } \\
\text { (meters- } \\
\text { NGVD of } \\
\text { 1929) }\end{array}$} & \multicolumn{2}{|c|}{ Water level } & \multirow[b]{2}{*}{$\begin{array}{l}\text { Use } \\
\text { of } \\
\text { water }\end{array}$} & \multicolumn{4}{|c|}{ Field determinations } \\
\hline & & & & & & & $\begin{array}{c}\text { Below } \\
\text { land } \\
\text { surface } \\
\text { (meters) } \\
\end{array}$ & $\begin{array}{c}\text { Date of } \\
\text { measure- } \\
\text { ment }\end{array}$ & & Date & $\begin{array}{l}\text { Specific } \\
\text { conduct- } \\
\text { ance } \\
\text { (micro- } \\
\text { mhos at } \\
25^{\circ} \mathrm{C} \text { ) }\end{array}$ & $\mathrm{pH}$ & $\begin{array}{l}\text { Tem- } \\
\text { per- } \\
\text { ature } \\
\left({ }^{\circ} \mathrm{C}\right)\end{array}$ \\
\hline$\star 80$ & S. Davis & $\ldots .$. & 21.3 & 152 & Ppv & 146 & 9.7 & $6-8-77$ & D & $6-8-77$ & 260 & --- & 18.5 \\
\hline 81 & S. Davis & ---- & 13.8 & 152 & Ppv & 147 & 8.7 & $6-8-77$ & D & $6-8-77$ & 270 & 6.9 & 17.5 \\
\hline 82 & J. Broughton & $-\cdots$ & 30 & 152 & Ppv & 148 & --- & $6-8-77$ & D & $6-8-77$ & 240 & 6.8 & 18.0 \\
\hline 83 & J. Broughton & $-\ldots$ & 9.8 & 152 & Ppv & 147 & 5.0 & $6-8-77$ & D & 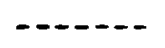 & -- & -- & -- \\
\hline 84 & J. Smith & $-\ldots$ & 10.3 & 152 & Ppv & 152 & 4.0 & $6-9-77$ & D & $6-9-77$ & 125 & 6.7 & 16.5 \\
\hline 85 & w. Griffin & $-\ldots$ & 31.1 & 152 & Ppv & 178 & 18.3 & $6-9-77$ & D & $6-9-77$ & 112 & 6.6 & 19.0 \\
\hline 86 & J. Neal & $\ldots$. & 35.3 & 152 & Ppv & 166 & 13.7 & $6-9-77$ & D & $6-9-77$ & 240 & 6.9 & 18.5 \\
\hline 87 & J. Neal & $--\cdot-$ & Spring & --- & Ppv & 157 & --- & $6-9-77$ & D & $6-9-77$ & 42 & 6.7 & 17.0 \\
\hline 88 & T. Davis & 1976 & 31.5 & 152 & Ppv & 154 & 7.5 & $6-9-77$ & D & $6-9-77$ & 65 & 6.5 & 17.0 \\
\hline 89 & T. Davis & 1976 & 29.2 & 152 & Ppv & 153 & 11.5 & $6-9-77$ & D & $6-9-77$ & 75 & 6.4 & 17.5 \\
\hline 90 & R. Evans & $\ldots$ & Spring &.- & Ppv & 148 & $\ldots$ & $6-9-77$ & D & $6-9-77$ & 36 & 5.8 & 16.0 \\
\hline$* 91$ & H. Griffin & ---- & 42 & 152 & Ppv & 131 & 18 & $6-8-77$ & D & $6-8-77$ & 305 & 7.4 & 17.5 \\
\hline 92 & L. Jones & ---- & -..-- & 152 & Ppv & 136 & $-\cdots$ & $6-8-77$ & D & $-\ldots$ &.- & -- & $-\cdots$ \\
\hline 93 & L. Jones & $\ldots$ & 8.3 & 762 & $\mathrm{Ppv}$ & 145 & 6.5 & $6-8-77$ & $\mathbf{N}$ & $6-8-77$ & 148 & 5.7 & 17.0 \\
\hline$\star 94$ & D. Dollars & ...... & 9.6 & 152 & Ppv & 138 & 7.9 & $6-14-77$ & D & $6-14-77$ & 240 & 6.5 & 16.5 \\
\hline * 95 & N. Armstrong & $-\ldots-$ & - - & 102 & Ppv & 139 & -..- & $6-14-77$ & D & $6-14-77$ & 310 & 6.9 & 19.5 \\
\hline 96 & N. Armstrong & $-\ldots$ & 8.0 & 914 & Ppv & 140 & 6.6 & $6-14-77$ & $\mathrm{~N}$ & - &.- & -- & $\cdots$ \\
\hline 97 & L. Bagwell & -.... & 29.7 & 152 & Ppv & 135 & 7.0 & $7-19-77$ & $\mathrm{~N}$ & $7-19-77$ & 215 & 6.6 & 24.0 \\
\hline 98 & T. Davis & $-\ldots$ & Spring & -- & $\mathrm{Ppv}$ & 145 & --- & $7-27-77$ & D & $\ldots$ & $\cdots$ & -- & --- \\
\hline 99 & E. Long & ...... & 23.6 & 152 & Ppv & 151 & 3.6 & $8-8-77$ & $\mathbf{N}$ & $-\cdots$ & --- & -- & --- \\
\hline 100 & E. Long & ----- & 11.1 & 152 & Ppv & 150 & 8.3 & $8-9-77$ & $\mathrm{~N}$ & $\ldots$ & --- & -- & 19.0 \\
\hline 101 & D. Kemp & -...-. & 5.2 & 914 & $\mathrm{Ppv}$ & 112 & 3.7 & $8-9-77$ & D & $8-9-77$ & 138 & 4.6 & 19.0 \\
\hline 102 & D. Kemp & 1931 & 8.5 & 152 & Ppv & 115 & 3.6 & $8-9-77$ & $\mathrm{~N}$ & $8-9-77$ & 140 & 6.2 & 19.0 \\
\hline 103 & J. Lyster & 1970 & 101.0 & 152 & Ppv & 87 & 5.3 & $8-9-77$ & $\mathbf{N}$ & $8-22-77$ & 600 & 8.3 & 19.5 \\
\hline 104 & C. Zennah & 1977 & 8.1 & 152 & Ppv & 163 & 3.2 & $8-17-77$ & $\mathbf{N}$ & - & -- & -- & -.. \\
\hline 105 & C. Zennah & 1977 & 11.5 & 152 & Ppv & 172 & 6.4 & $8-17-77$ & $\mathbf{N}$ & $-\cdots-$ & -- & -- & $-\cdots$ \\
\hline 106 & E. Wood & 1978 & 37.2 & 152 & Kck & 154 & 30.2 & $9-20-78$ & D & $-\ldots$ & -- & -- & --- \\
\hline 107 & D. Cunningham & $\cdots$ & $-\cdots-$ & $-\cdot-$ & Kck & 140 & -- & $-\ldots$ & D & $-\cdots$ & $--\cdot$ & --- & ---- \\
\hline$\star 108$ & A. Malatino & ----- & 27.4 & 152 & Kck & 177 & 22 & $3-31-77$ & D & $4-1-75$ & 16 & 5.2 & 13.0 \\
\hline 109 & M. Barger & $-\ldots$ & 8.4 & 610 & Kck & 151 & 7.9 & $5-15-78$ & $\mathbf{N}$ & - - - & $-\cdot$ & --- & $\cdots$ \\
\hline
\end{tabular}

* Standard chemical analysis available; see table 4. 
Table 3.--Records of test wells drilled in and near study areas in Tuscaloosa County

(Well numbers correspond with those on plate 4)

Water-bearing unit: Ppv, Pottsville Formation; Kck, Coker Formation.

Altitude: Altitudes determined by aneroid barometer.

\begin{tabular}{|c|c|c|c|c|c|c|c|c|}
\hline \multirow[b]{2}{*}{$\begin{array}{l}\text { We11 } \\
\text { number }\end{array}$} & \multirow[b]{2}{*}{$\begin{array}{l}\text { Date } \\
\text { com- } \\
\text { pleted }\end{array}$} & \multirow[b]{2}{*}{$\begin{array}{l}\text { Depth } \\
\text { of well } \\
\text { (meters) }\end{array}$} & \multirow[b]{2}{*}{$\begin{array}{l}\text { Diame- } \\
\text { ter of } \\
\text { casing } \\
\text { (milli- } \\
\text { meters) }\end{array}$} & \multirow[b]{2}{*}{$\begin{array}{l}\text { Water } \\
\text { bearing } \\
\text { unit }\end{array}$} & \multirow{2}{*}{$\begin{array}{l}\text { Altitude } \\
\text { of land } \\
\text { surface } \\
\text { (meters- } \\
\text { NGVD of } \\
1929 \text { ) }\end{array}$} & \multicolumn{2}{|c|}{ Water level } & \multirow[b]{2}{*}{ Remarks } \\
\hline & & & & & & $\begin{array}{c}\text { Below } \\
\text { land } \\
\text { surface } \\
\text { (meters) }\end{array}$ & $\begin{array}{l}\text { Date of } \\
\text { measure- } \\
\text { ment }\end{array}$ & \\
\hline TW-1 & $6-13-78$ & 25.6 & 152 & Kck & 153 & 14.0 & $6-13-78$ & $\begin{array}{l}\text { Casing from surface to } 22.6 \mathrm{~m} ; 102 \mathrm{~mm} \text { screen from } \\
22.6 \text { to } 25.6 \mathrm{~m} \text {. Drawdown } 2.85 \mathrm{~m} \text { after pumping } \\
5.6 \mathrm{~L} / \mathrm{s} \text { for } 17 \text { hours on } 10-24-78 \text {. }\end{array}$ \\
\hline TW-2 & $8-3-78$ & 34.1 & 152 & Kck & 180 & 30.2 & $9-29-78$ & $\begin{array}{l}\text { Casing from surface to } 31.1 \mathrm{~m} ; 127 \mathrm{~mm} \text { screen from } \\
31.1 \text { to } 34.1 \mathrm{~m} \text {. }\end{array}$ \\
\hline TW-3 & $6-25-78$ & 88.4 & 152 & Ppv & 193 & 32.3 & $6-25-78$ & Casing from surface to $8.8 \mathrm{~m}$; none below. \\
\hline$T W-4$ & $6-20-78$ & 105.8 & 152 & Ppv & 195 & 27.4 & $6-25-78$ & Casing from surface to $7.6 \mathrm{~m}$; none below. \\
\hline TW-5 & $7-6-78$ & 18.3 & 152 & Ppv & 158 & 12.3 & $9-20-78$ & Casing from surface to $9.8 \mathrm{~m}$; none below. \\
\hline$T W-6$ & $7-7-78$ & 61.0 & 152 & Ppv & 164 & 29.6 & $9-20-78$ & Casing from surface to $26.5 \mathrm{~m}$; none below. \\
\hline$T W-7$ & $7-13-78$ & 45.7 & 152 & Ppv & 139 & 24.1 & $9-27-78$ & Casing from surface to $10.4 \mathrm{~m}$; none below. \\
\hline TW- 8 & $7-14-78$ & 45.7 & 152 & Ppv & 147 & 23.1 & $9-20-78$ & Casing from surface to $6.7 \mathrm{~m}$; none below. \\
\hline TW-9 & $7-19-78$ & 63.1 & 152 & $\mathrm{Kck} / \mathrm{Ppv}$ & 163 & 12.3 & $9-20-78$ & Casing from surface to $24.4 \mathrm{~m}$; none below. \\
\hline $\mathrm{TW}-10$ & $7-21-78$ & 61.0 & 152 & Ppv & 163 & $-\ldots$ & $-\ldots$ & Casing from surface to $19.8 \mathrm{~m}$; none below. \\
\hline$T W-11$ & $7-21-78$ & 61.0 & 152 & Ppv & 182 & 21.8 & $10-16-78$ & Casing from surface to $26.8 \mathrm{~m}$; none below. \\
\hline$T W-12$ & $7-26-78$ & 81.4 & 152 & Ppv & 178 &.-- & -..... & Casing from surface to $14.9 \mathrm{~m}$; none below. \\
\hline $\mathrm{TW}-13$ & $7-27-78$ & 50.6 & 152 & Ppv & 177 & 21.2 & $10-13-78$ & Casing from surface to $12.3 \mathrm{~m}$; none below. \\
\hline
\end{tabular}


Table 3.--Records of test wells drilled in and near study areas in Tuscaloosa County--Continued

\begin{tabular}{|c|c|c|c|c|c|c|c|c|}
\hline \multirow[b]{2}{*}{$\begin{array}{c}\text { Well } 1 \\
\text { number }\end{array}$} & \multirow[b]{2}{*}{$\begin{array}{c}\text { Date } \\
\text { com- } \\
\text { pleted }\end{array}$} & \multirow[b]{2}{*}{$\begin{array}{l}\text { Depth } \\
\text { of we11 } \\
\text { (meters) }\end{array}$} & \multirow[b]{2}{*}{$\begin{array}{l}\text { Diame- } \\
\text { ter of } \\
\text { casing } \\
\text { (milli- } \\
\text { meters) }\end{array}$} & \multirow[b]{2}{*}{$\begin{array}{c}\text { Water } \\
\text { bearing } \\
\text { unit }\end{array}$} & \multirow{2}{*}{$\begin{array}{l}\text { Altitude } \\
\text { of land } \\
\text { surface } \\
\text { (meters- } \\
\text { NGVD of } \\
1929 \text { ) }\end{array}$} & \multicolumn{2}{|c|}{ Water level } & \multirow[b]{2}{*}{ Remarks } \\
\hline & & & & & & $\begin{array}{l}\text { Below } \\
\text { land } \\
\text { surface } \\
\text { (meters) }\end{array}$ & $\begin{array}{c}\text { Date of } \\
\text { measure- } \\
\text { ment }\end{array}$ & \\
\hline$T W-14$ & $8-7-78$ & 45.7 & 152 & Ppv & 189 & 22.2 & $10-16-78$ & Casing from surface to $23.6 \mathrm{~m}$; none below. \\
\hline TW-15 & $8-8-78$ & 19.8 & 152 & Kck & 182 & 15.2 & $10-2-78$ & $\begin{array}{l}\text { Casing from surface to } 16.0 \mathrm{~m} ; 102 \mathrm{~mm} \text { from } 19.0 \text { to } \\
19.8 \mathrm{~m} ; 102 \mathrm{~mm} \text { screen from } 16 \text { to } 19.0 \mathrm{~m} \text {. Draw- } \\
\text { down } 0.45 \mathrm{~m} \text { after pumping } 0.26 \mathrm{~L} / \mathrm{s} \text { for } 1 \text { hour } \\
\text { and } 45 \text { minutes on } 10-31-78 .\end{array}$ \\
\hline
\end{tabular}

\begin{tabular}{|c|c|c|c|c|c|c|c|c|}
\hline TW-16 & $8-9-78$ & 31.1 & 152 & Kck & 178 & 24.8 & $10-16-78$ & $\begin{array}{l}\text { Casing from surface to } 27.0 \mathrm{~m} ; 102 \mathrm{~mm} \text { from } 30 \text { to } \\
\quad 31.1 \mathrm{~m} ; 102 \mathrm{~mm} \text { screen from } 27.0 \text { to } 30 \mathrm{~m} \text {. }\end{array}$ \\
\hline$T W-17$ & $8-11-78$ & 51.8 & 152 & Ppv & 183 & 22.4 & $10-16-78$ & Casing from surface to $32.3 \mathrm{~m}$; none below. \\
\hline$T W-18$ & $8-16-78$ & 68.9 & 152 & Ppv & 160 & 25.1 & $10-16-78$ & Casing from surface to $18.3 \mathrm{~m}$; none below. \\
\hline$T W-19$ & $8-23-78$ & 50.6 & 152 & Ppv & 186 & $\cdots$ & $\cdots+\cdots$ & Casing from surface to $8.8 \mathrm{~m}$; none below. \\
\hline$T W-20$ & $8-24-78$ & 63.1 & 152 & Ppv & 191 & $-\cdots$ & -- & Casing from surface to $12.5 \mathrm{~m}$; none below. \\
\hline$T W-21$ & $8-29-78$ & 63.1 & 152 & Ppv & -- & $-\cdots$ & $-\cdots+-$ & Casing from surface to $6.4 \mathrm{~m}$; none below. \\
\hline TW-22 & $8-31-78$ & 93.6 & 152 & Ppv & 203 & $-\cdots$ & $-\cdots-1$ & Casing from surface to $18.3 \mathrm{~m}$; none below. \\
\hline$T W-23$ & $9-1-78$ & 97.5 & 152 & Ppv & 154 & $-\cdots$ & $-\cdots-\cdots$ & Casing from surface to $5.8 \mathrm{~m}$; none below. \\
\hline$T W-24$ & $9-6-78$ & 17.7 & 152 & Kck & 152 & --- & ------ & $\begin{array}{l}\text { Casing from surface to } 14 \mathrm{~m} ; 102 \mathrm{~mm} \text { from } 17.1 \text { to } \\
17.7 \mathrm{~m} ; 102 \mathrm{~mm} \text { screen from } 14 \text { to } 17.1 \mathrm{~m} \text {. }\end{array}$ \\
\hline$T W-25$ & $9-8-78$ & 45.7 & 152 & Ppv & 147 & 14.3 & $10-6-78$ & Casing from surface to $12.5 \mathrm{~m}$; none below. \\
\hline
\end{tabular}


Table 3.--Records of test wells drilled in and near study areas in Tuscaloosa County--Continued

\begin{tabular}{|c|c|c|c|c|c|c|c|c|}
\hline $\begin{array}{c}\text { Wel1 } \\
\text { number }\end{array}$ & $\begin{array}{c}\text { Date } \\
\text { com- } \\
\text { pleted }\end{array}$ & $\begin{array}{l}\text { Depth } \\
\text { of well } \\
\text { (meters) }\end{array}$ & $\begin{array}{l}\text { Diame- } \\
\text { ter of } \\
\text { casing } \\
\text { (milli- } \\
\text { meters) }\end{array}$ & $\begin{array}{l}\text { Water } \\
\text { bearing } \\
\text { unit }\end{array}$ & $\begin{array}{l}\text { Altitude } \\
\text { of land } \\
\text { surface } \\
\text { (meters- } \\
\text { NGVD of } \\
\text { 1929) }\end{array}$ & $\begin{array}{c}\text { Water } \\
\text { Below } \\
\text { land } \\
\text { surface } \\
\text { (meters) }\end{array}$ & $\begin{array}{c}\text { Date of } \\
\text { measure- } \\
\text { ment }\end{array}$ & Remarks \\
\hline$T W-26$ & $9-11-78$ & 37.8 & 152 & Ppv & 120 & 5.2 & $9-19-78$ & $\begin{array}{l}\text { Casing from surface to } 9.4 \mathrm{~m} \text {; none below. Draw- } \\
\text { down } 2.3 \mathrm{~m} \text { after pumping } 1.3 \mathrm{~L} / \mathrm{s} \text { for } 24 \text { hours } \\
\text { on } 10-25-78 \text {. Drawdown } 3.6 \mathrm{~m} \text { after pumping } 3.5 \\
\mathrm{~L} / \mathrm{s} \text { for } 7 \text { hours and } 50 \text { minutes on } 11-2-78 \text {. }\end{array}$ \\
\hline TW-27 & $9-13-78$ & 81.7 & 152 & Ppv & 171 & 71.3 & $9-20-78$ & Casing from surface to $22.6 \mathrm{~m}$; none below. \\
\hline$T W-28$ & $9-15-78$ & 75.6 & 152 & Ppv & 185 & 55.3 & $9-20-78$ & Casing from surface to $7.9 \mathrm{~m}$; none below. \\
\hline$T W-29$ & $9-19-78$ & 44.2 & 152 & Ppv & 136 & $-\ldots$ & -....... & Casing from surface to $6.1 \mathrm{~m}$; none below. \\
\hline$T W-30$ & $9-20-78$ & 37.8 & 152 & Ppv & 125 & 14.0 & $9-25-78$ & Casing from surface to $5.1 \mathrm{~m}$; none below. \\
\hline
\end{tabular}


Table 4.--Quality of water from selected wells and springs

(in milligrams per liter, except as indicated)

\begin{tabular}{|c|c|c|c|c|c|c|c|c|c|c|c|}
\hline $\begin{array}{l}\text { Well number } \\
\text { Date of collection } \\
\text { Depth of well (m) } \\
\text { Water bearing formation }\end{array}$ & $\begin{array}{l}6 \\
5-17-70 \\
30.5 \\
\text { Coker }\end{array}$ & $\begin{array}{l}7 \\
2-3-77 \\
\text { Spring } \\
\text { Coker } \\
\end{array}$ & $\begin{array}{c}32 \\
10-6-77 \\
13.7 \\
\text { Coker }\end{array}$ & $\begin{array}{l}34 \\
10-6-77 \\
21.3 \\
\text { Coker }\end{array}$ & $\begin{array}{c}53 \\
9-14-77 \\
56.4 \\
\text { Pottsville } \\
\end{array}$ & $\begin{array}{c}55 \\
9-14-77 \\
16 \\
\text { Pottsville } \\
\end{array}$ & $\begin{array}{c}80 \\
9-28-77 \\
21.3 \\
\text { Pottsville } \\
\end{array}$ & $\begin{array}{c}91 \\
9-28-77 \\
41.7 \\
\text { Pottsville } \\
\end{array}$ & $\begin{array}{c}94 \\
9-14-77 \\
9.4 \\
\text { Pottsville } \\
\end{array}$ & $\begin{array}{c}95 \\
9-15-77 \\
--- \\
\text { Pottsville } \\
\end{array}$ & $\begin{array}{c}108 \\
4-1-75 \\
27.4 \\
\text { Coker } \\
\end{array}$ \\
\hline $\begin{array}{r}\text { Specific conductance, } \\
\left(\text { micromhos at } 25^{\circ} \mathrm{C}\right)\end{array}$ & 16 & 25 & 28 & 14 & 260 & 408 & 302 & 365 & 277 & 285 & 16 \\
\hline $\begin{array}{l}\text { Temperature }\left({ }^{\circ} \mathrm{C}\right) \\
\mathrm{pH} \text { (units) }\end{array}$ & $\begin{array}{r}22.0 \\
5.7\end{array}$ & $\begin{array}{l}5.0 \\
5.3\end{array}$ & $\begin{array}{r}17.0 \\
5.9\end{array}$ & $\begin{array}{r}17.5 \\
4.9\end{array}$ & $\begin{array}{r}20.5 \\
6.8\end{array}$ & $\begin{array}{r}22.0 \\
7.2\end{array}$ & $\begin{array}{r}18.5 \\
6.8\end{array}$ & $\begin{array}{r}18.5 \\
7.6\end{array}$ & $\begin{array}{r}17.0 \\
6.9\end{array}$ & 6.9 & $\begin{array}{r}13.0 \\
5.4\end{array}$ \\
\hline Color (units) 1/ & $\ldots$ & 0 & $\cdots$ & $\cdots$ & $\cdots$ & $-\ldots$ & $-\ldots$ & $\ldots-$ & $-\ldots$ & $\ldots$ & $-\cdots$ \\
\hline Hardness as $\mathrm{CaC}_{3}$ & 2 & 9 & 10 & 3 & 120 & 220 & 130 & 69 & 140 & 150 & 2 \\
\hline $\begin{array}{l}\text { Noncarbonate hardness } \\
\text { Total acidity as } \mathrm{H}^{+}\end{array}$ & 0 & 4 & 0 & 0 & 0 & 9 & 0 & 0 & 8 & 8 & 0 \\
\hline Total acidity as $\mathrm{H}^{+}$ & $-\cdots$ & 0 & $\cdots$ & $\cdots$ & $-\cdots$ & $\cdots-$ & $-\cdots$ & 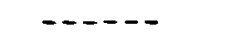 & $\cdots$ & $-\cdots$ & $-\ldots$ \\
\hline $\begin{array}{l}\text { Total acidity as } \mathrm{CaCO}_{3} \\
\text { Calcium }(\mathrm{Ca})\end{array}$ & $-\cdots$ & 0 & $\cdots$ & --- & $-\cdots$ & $\cdots$ & $-\cdots$ & $\cdots$ & $\cdots$ & -.-- & $\cdots$ \\
\hline $\begin{array}{l}\text { Calcium (Ca) } \\
\text { Magnesium (Mg) }\end{array}$ & $-\cdots$ & 1.9 & 3.6 & .5 & 26 & 46 & 26 & 16 & 31 & 41 & .5 \\
\hline Magnesium (Mg) & $\cdots$ & 1.0 & .3 & .4 & 14 & 26 & 15 & 7.1 & 15 & 11 & .3 \\
\hline Sodium (Na) & $-\cdots$ & 1.3 & .8 & .6 & 12 & 8.7 & 14 & 54 & 8.9 & 7.6 & .6 \\
\hline Percent sodium $(\%)$ & $-\ldots$ & 21 & 14 & 28 & 17 & 8 & 19 & 63 & 12 & 10 & --- \\
\hline $\begin{array}{l}\text { Sodium adsorption ratio } \\
\text { (SAR) }\end{array}$ & $\ldots$ & .2 & .1 & .2 & .5 & .3 & .5 & 2.8 & .3 & .3 & $\cdots--$ \\
\hline Potassium (K) & ...- & 1.2 & .3 & .4 & 1.1 & 2.0 & 1.9 & .8 & 7.0 & .6 & 1.1 \\
\hline Bicarbonate $\left(\mathrm{HCO}_{3}\right)$ & 5 & 6 & 15 & 6 & 160 & 260 & 180 & 220 & 160 & 170 & 7 \\
\hline Carbon dioxide $\left(\mathrm{CO}_{2}\right)$ &.-- & 48 & 30 & 121 & 41 & 26 & 46 & 8.8 & 32 & 34 & -... \\
\hline Carbonate $\left(\mathrm{CO}_{3}\right)$ & 0 & 0 & 0 & 0 & 0 & 0 & 0 & 0 & 0 & 0 & 0 \\
\hline Sulfate $\left(\mathrm{SO}_{4}\right)$ & --- & -..- & .6 & .0 & 7.4 & 16 & 10 & 4.2 & 13 & 11 & .2 \\
\hline Chloride (C1) & 1.0 & 3.8 & 1.4 & .6 & 5.2 & 1.7 & 3.0 & 3.6 & 9.6 & 4.1 & .4 \\
\hline Fluoride (F) & .1 & .1 & .0 & .0 & .1 & .1 & .1 & .1 & .1 & .1 & .0 \\
\hline Silica $\left(\mathrm{SiO}_{2}\right)$ & $\ldots$ & 6.2 & 9.6 & 7.3 & 29 & 29 & 21 & 17 & 20 & 23 & 7.6 \\
\hline $\begin{array}{l}\text { Dissolved solids } \\
\text { (calculated) }\end{array}$ & $\cdots$ & $\cdots$ & --- & $\cdots$ & 176 & 258 & 180 & 211 & 194 & 183 & $-\cdots$ \\
\hline Total nitrate (N) &.-- & .21 & .04 & .05 & .57 & .02 & .90 & .06 & 2.4 & .05 & .2 \\
\hline Total nitrate $\left(\mathrm{NO}_{3}\right)$ & --- &.-- & .18 & .22 & 2.5 & .09 & .40 & .27 & 11 & .22 & 1.1 \\
\hline Total nitrite (N) & -..- & .00 & -...- & -... & -...- & $-\ldots$ & --- & $\ldots$ & $-\ldots$ & $\ldots-$ & \\
\hline Total organic nitrogen (N) &.-- & --- & .00 & .00 & .14 & .06 & .00 & .09 & .18 & .00 & $\ldots$ \\
\hline Total Kjeldahl nitrogen (N) & -... & .10 & $--\cdot-$ & -... & $-\cdots$ & $-\infty-$ & $-\ldots$ & $-\ldots-$ & 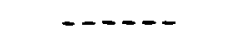 & -...- & $--\cdot-$ \\
\hline Phosphate $\left(\mathrm{PO}_{4}\right)$ & $\cdots$ & $-\cdots$ & ---- & $-\cdots$ & -..- & -...-- & -.... & -..... & $\cdots$ & $\cdots$ & $\cdots$ \\
\hline
\end{tabular}


Table 4.--Quality of water from selected wells and springs--Continued

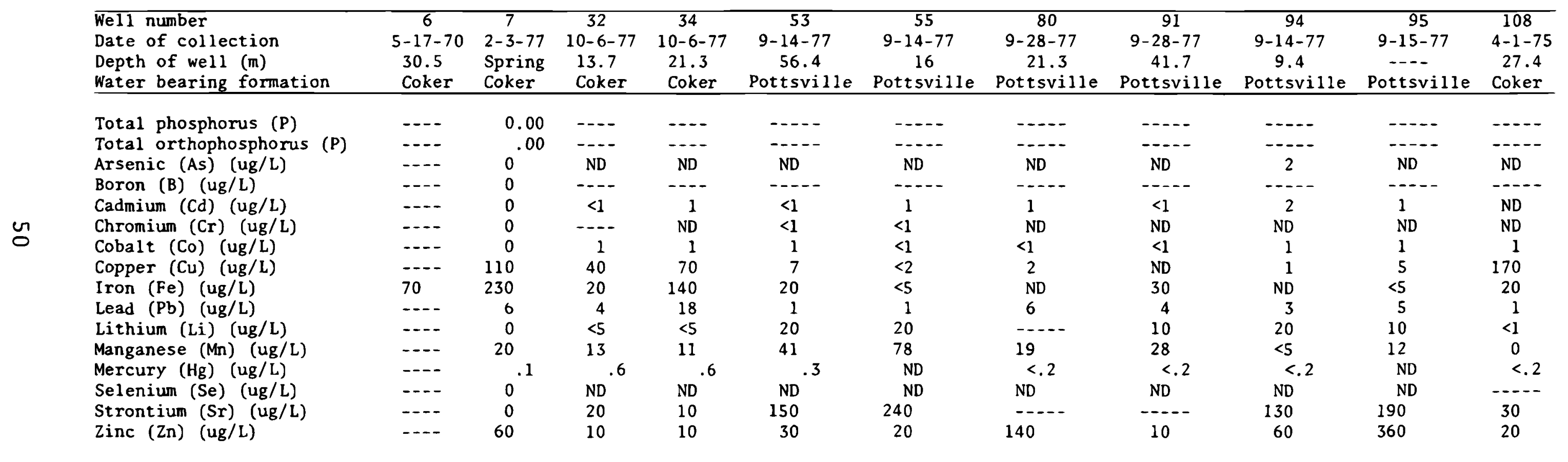

ND - Not detected

1/ - Plat.inum-cobalt scale units 
Table 5.--Summary of surface water data collection network

(Site numbers correspond to those on figure 5)

\begin{tabular}{|c|c|c|c|c|c|c|c|c|}
\hline \multirow[b]{2}{*}{$\begin{array}{l}\text { Site } \\
\text { number }\end{array}$} & \multirow[b]{2}{*}{ Name } & \multirow[b]{2}{*}{$\begin{array}{l}\quad \text { USGS } \\
\text { station } \\
\text { number }\end{array}$} & \multirow[b]{2}{*}{$\begin{array}{l}\text { Drainage } \\
\text { area } \\
\left(\mathrm{km}^{2}\right) \\
\end{array}$} & \multirow[b]{2}{*}{$\begin{array}{l}\text { Period } \\
\text { of } \\
\text { record }\end{array}$} & \multicolumn{4}{|c|}{ Type data and sampling frequency $1 /$} \\
\hline & & & & & Streanflow & $\begin{array}{l}\text { Water } \\
\text { quality }\end{array}$ & $\begin{array}{l}\text { Suspended } \\
\text { sediment }\end{array}$ & $\begin{array}{l}\text { Aquatic } \\
\text { biology }\end{array}$ \\
\hline \multicolumn{9}{|c|}{ Bear Creek Basin } \\
\hline 1 & Bear Creek near Samantha & 02463900 & 39.1 & Oct. 1976-Sept. 1978 & C & C & D & M \\
\hline 2 & Dry Branch near Samantha & 02463890 & $\begin{array}{l}1.86 \\
\text { Blue }\end{array}$ & $\begin{array}{l}\text { Nov. 1976-Sept. } 1978 \\
\text { Creek Basin }\end{array}$ & $M, F$ & $\mathbf{M}, \mathbf{F}$ & $M, F$ & M \\
\hline 3 & Blue Creek near Oakman & 02462600 & 13.8 & $\begin{array}{l}\text { 1959-65 and Oct. 1976- } \\
\text { Sept. } 1978\end{array}$ & C & $M, F$ & $M, F$ & M \\
\hline & & & Turkey & Creek Basin & & & & \\
\hline 4 & Turkey Creek near Tuscaloosa & 02464145 & 15.9 & Nov. 1976-Sept. 1978 & $M, F$ & $\mathbf{M}, \mathbf{F}$ & $\mathbf{M}, \mathbf{F}$ & M \\
\hline \multicolumn{9}{|c|}{ Yellow Creek Basin } \\
\hline 5 & Yellow Creek above Northport & 02462980 & 9.43 & Nov. 1976-Sept. 1978 & $M, F$ & $\mathbf{M}, \mathbf{F}$ & $M, F$ & M \\
\hline 6 & $\begin{array}{l}\text { Tributary to Yellow Creek } \\
\text { near Northport }\end{array}$ & 02462985 & 6.45 & Nov. 1976-Sept. 1978 & $M, F$ & $\mathbf{M}, \mathbf{F}$ & $M, F$ & M \\
\hline 7 & Yellow Creek near Northport & 02462990 & 21.3 & Oct. 1976-Sept. 1978 & C & C & D & M \\
\hline
\end{tabular}

1/ C - continuous, D - daily, M - monthly, F - flood events. 
Table 6.--Monthly and annual mean stream discharge for sites 1,3 , and 7 , October 1976-September 1978

(cubic meters per second)

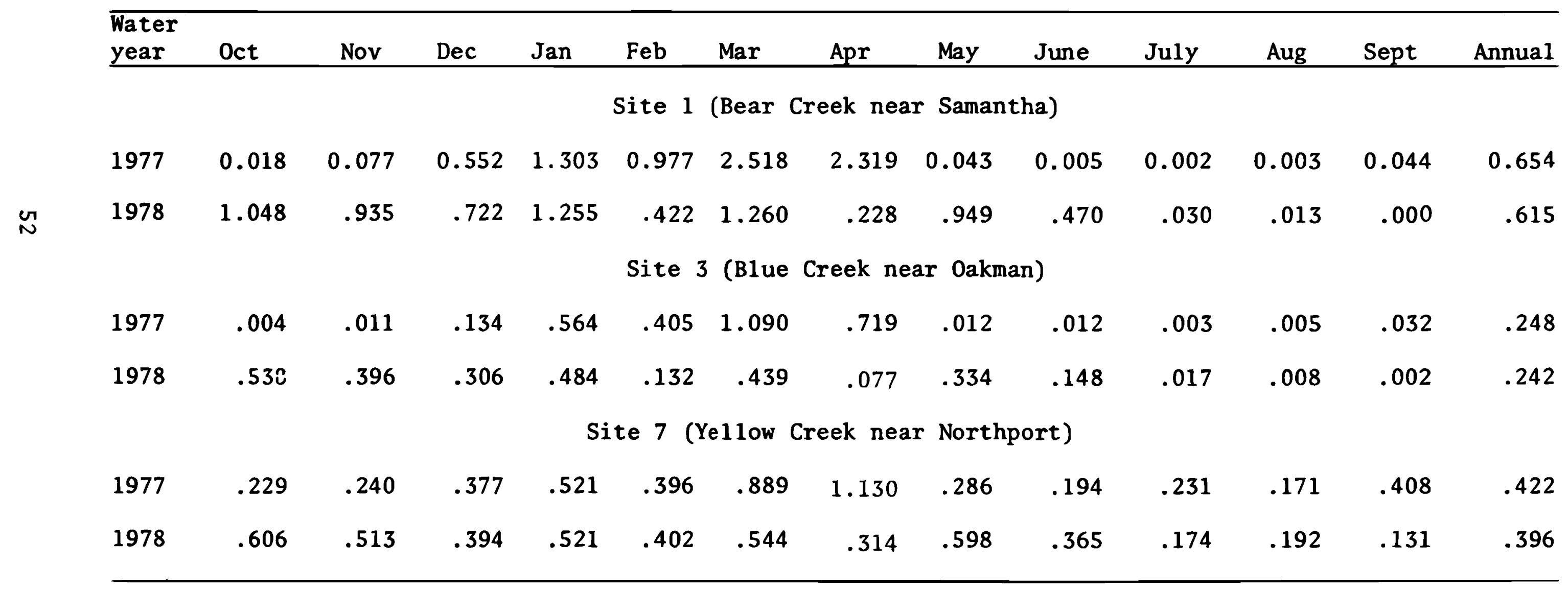


Table 8.--Summary of selected chemical and physical characteristics of water at site 1 (Bear Creek near Samantha)

\begin{tabular}{|c|c|c|c|c|}
\hline Property & $\begin{array}{c}\text { Number } \\
\text { of } \\
\text { analyses }\end{array}$ & Mean & Range & Units \\
\hline Discharge. & 41 & 9.1 & $0.01-72$ & $m^{3} / s$ \\
\hline Specific conductance $\left(\right.$ at $\left.25^{\circ} \mathrm{C}\right) \ldots \ldots \ldots \ldots$ & 45 & 33 & $16-94$ & unhos/cm \\
\hline 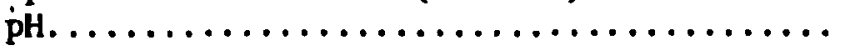 & 40 & $1 / 6.4$ & $5.4-7.5$ & units \\
\hline 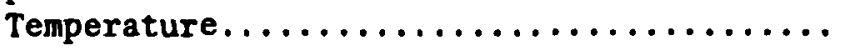 & 45 & 14.0 & $2.0-27.0$ & ${ }^{\circ} \mathrm{C}$ \\
\hline 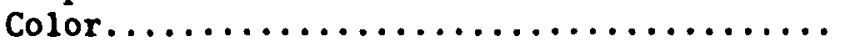 & 5 & 23 & $10-40$ & units \\
\hline Dissolved oxygen.................... & 12 & 9.4 & $4.8-12.4$ & $\mathbf{m g} / \mathbf{L}$ \\
\hline Hardness $\left(a s \mathrm{CaCO}_{3}\right) \ldots \ldots \ldots \ldots \ldots \ldots$ & 19 & 8 & $1-12$ & mg/L \\
\hline Noncarbonate hardness.................. & 19 & 1 & $0-5$ & $\mathbf{m g} / \mathrm{L}$ \\
\hline Acidity as $H^{+} \ldots \ldots \ldots \ldots \ldots \ldots \ldots \ldots \ldots$ & 23 & .0 & $.0-.2$ & $\mathbf{m g} / \mathrm{L}$ \\
\hline Acidity as $\mathrm{CaCO}_{3} \ldots \ldots \ldots \ldots \ldots \ldots \ldots$ & 23 & .7 & $.0-10$ & $\mathbf{m g} / \mathrm{L}$ \\
\hline 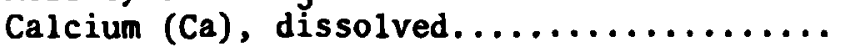 & 19 & 1.5 & $.1-2.7$ & $\operatorname{mig} / \mathrm{L}$ \\
\hline 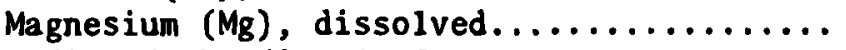 & 19 & .9 & $.1-1.6$ & $\mathbf{m g} / \mathbf{L}$ \\
\hline 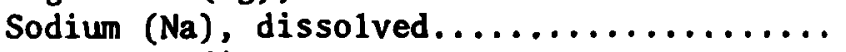 & 18 & 1.9 & $.4-3.5$ & $\mathrm{mg} / \mathrm{L}$ \\
\hline Percent sodium..................... & 17 & 32 & $24-46$ & $\%$ \\
\hline Sodium-adsorption ratio............... & 18 & .3 & $.2-.5$ & ----- \\
\hline 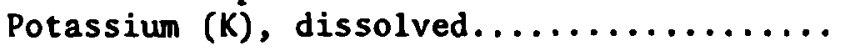 & 17 & .9 & $.4-1.8$ & mg/L \\
\hline Bi carbonate $\left(\mathrm{HCO}_{3}\right) \ldots \ldots \ldots \ldots \ldots \ldots$ & 33 & 11 & $5-32$ & $\mathrm{mg} / \mathrm{L}$ \\
\hline Carbon dioxide $\left(\mathrm{CO}_{2}\right) \ldots \ldots \ldots \ldots \ldots \ldots \ldots$ & 32 & 13 & $.3-96$ & $\mathrm{mg} / \mathrm{L}$ \\
\hline Carbonate $\left(\mathrm{CO}_{3}\right) \ldots \ldots \ldots \ldots \ldots \ldots \ldots$ & 30 & 0 & 0 & $\mathrm{mg} / \mathrm{L}$ \\
\hline Sulfate $\left(\mathrm{SO}_{4}\right)$, dissolved............... & 34 & 4.1 & $1.4-14$ & $\mathrm{mg} / \mathrm{L}$ \\
\hline 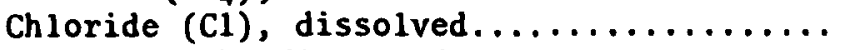 & 10 & 1.6 & $.6-2.6$ & $\mathrm{mg} / \mathrm{L}$ \\
\hline 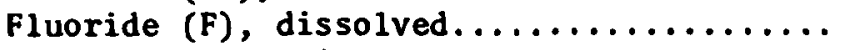 & 6 & .1 & $.0-.3$ & $\mathrm{mg} / \mathrm{L}$ \\
\hline 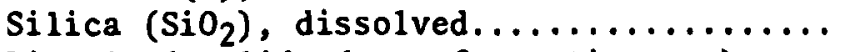 & 6 & 7.8 & $7.0-8.6$ & $\mathrm{mg} / \mathrm{L}$ \\
\hline Dissolved solids (sum of constituents)..... & 6 & 25 & $21-28$ & $\mathrm{mg} / \mathrm{L}$ \\
\hline Total nitrate $(N) \ldots \ldots \ldots \ldots \ldots \ldots$ & 5 & 0.05 & $.01-.08$ & $\mathrm{mg} / \mathrm{L}$ \\
\hline Total nitrite $(N) \ldots \ldots \ldots \ldots \ldots \ldots$ & 5 & 0 & $.0-.01$ & $m g / L$ \\
\hline Total Kjeldahl nitrogen $(N) \ldots \ldots \ldots \ldots$ & 5 & .14 & $.05-.24$ & $\mathrm{mg} / \mathrm{L}$ \\
\hline Total nitrogen $(N) \ldots \ldots \ldots \ldots \ldots \ldots$ & 5 & .19 & $.11-.30$ & $m g / L$ \\
\hline Total nitrogen $\left(\mathrm{NO}_{3}\right) \ldots \ldots \ldots \ldots \ldots \ldots$ & 4 & .70 & $.49-1.1$ & $\mathrm{mg} / \mathrm{L}$ \\
\hline 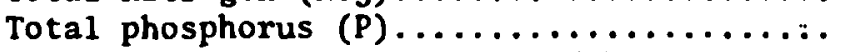 & 5 & .01 & $.01-.02$ & $\mathrm{mg} / \mathrm{L}$ \\
\hline Total orthophorus phosphorus (P) ......... & 5 & .00 & .00 & $\mathrm{mg} / \mathrm{L}$ \\
\hline Total organic carbon (C) .............. & 4 & 5.2 & $2.2-9.2$ & $\mathrm{mg} / \mathrm{L}$ \\
\hline Total inorganic carbon (C).............. & 3 & 10 & $6.4-17$ & $\mathbf{m g} / \mathrm{L}$ \\
\hline 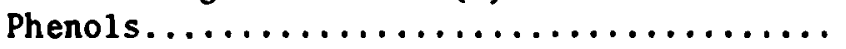 & 3 & 1 & $0-3$ & ug/L \\
\hline Alpha, gross dissolved as $U$ natural........ & 2 & .7 & $0-1.3$ & $\mathrm{ug} / \mathrm{L}$ \\
\hline $\begin{array}{l}\text { Beta, gross dissolved as Cs }-137 \ldots \ldots \ldots \ldots \\
\text { Beta, gross dissolved as strontium/ }\end{array}$ & 3 & 1.3 & $.6-2.0$ & $\mathrm{PC} / \mathrm{L}$ \\
\hline 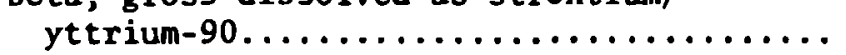 & 3 & 1.2 & $.6-1.9$ & PC/L \\
\hline Radium-226, dissolved, Radon method.... & 3 & .06 & $.03-.1$ & PC/L \\
\hline Uranium, natural dissolved (U)...... & 2 & .0 & .0 & $\mathbf{u g} / \mathrm{L}$ \\
\hline
\end{tabular}

\begin{tabular}{|c|c|c|c|c|c|c|c|c|c|c|c|c|}
\hline \multirow[b]{2}{*}{ Property } & \multicolumn{4}{|c|}{ Dissolved } & \multicolumn{4}{|c|}{$\begin{array}{c}\text { Total recoverable in a } \\
\text { water-suspended sediment solution }\end{array}$} & \multicolumn{4}{|c|}{ Recoverable from bottom material } \\
\hline & $\begin{array}{c}\text { Number } \\
\text { of } \\
\text { analyses }\end{array}$ & Mean & Range & Units & $\begin{array}{c}\text { Number } \\
\text { of } \\
\text { analyses } \\
\end{array}$ & Mean & Range & Units & $\begin{array}{c}\begin{array}{c}\text { Number } \\
\text { of } \\
\text { analyses }\end{array} \\
\end{array}$ & Mean & Range & Units \\
\hline Aluminum & 19 & 30 & $0-90$ & ug/L & 15 & 1500 & $100-4000$ & ug/L & 3 & 1700 & $600-2800$ & $u g / g$ \\
\hline Arsenic & 4 & 1 & $0-1$ & $\mathrm{ug} / \mathrm{L}$ & 2 & 0 & 0 & $\mathrm{ug} / \mathrm{L}$ & 3 & 4.7 & $0-8$ & ug/g \\
\hline Boron & 4 & 10 & $0-20$ & $\mathrm{ug} / \mathrm{L}$ & 3 & 10 & 10 & $u g / L$ & 3 & 0 & 0 & ug/g \\
\hline Cadmium & 4 & 0 & 0 & $\mathrm{ug} / \mathrm{L}$ & 3 & 0 & 0 & ug/L & 3 & $<10$ & $<10$ & ug/g \\
\hline Chromium & 4 & 1 & $0-1.0$ & $\mathrm{ug} / \mathrm{L}$ & 1 & 10 & 10 & ug/L & 1 & 20 & 20 & $\mathrm{ug} / \mathrm{g}$ \\
\hline Cobalt & 4 & 10 & 10 & ug/L & 3 & 10 & 10 & ug/L & 3 & $<10$ & $<10$ & $\mathrm{ug} / \mathrm{g}$ \\
\hline Copper & 4 & 1 & $0-3$ & $u g / L$ & 3 & 10 & 10 & ug/L & 3 & $<10$ & $<10$ & ug/g \\
\hline Iron & 19 & 80 & $10-250$ & ug/L & 16 & 3500 & $400-10000$ & ug/L & 3 & 7700 & $990-17000$ & ug/g \\
\hline Lead & 4 & 1 & $0-5$ & ug/L & 3 & 10 & 10 & ug/L & 3 & $<10$ & $<10$ & $\mathrm{ug} / \mathrm{g}$ \\
\hline Lithium & 4 & 0 & 0 & ug/L & 3 & 0 & 0 & $u g / L$ &..-- & ----- & $---1---$ & $\ldots$ \\
\hline Manganese & 15 & 27 & $0.0-60$ & ug/t & 15 & 110 & $20-280$ & ug/L & 2 & 230 & $220-240$ & $u g / g$ \\
\hline Mercury & 3 & .0 & $0-.5$ & ug/L & 2 & .5 & $.0-.5$ & $\mathrm{ug} / \mathrm{L}$ & 3 & 0 & 0 & ug/g \\
\hline Selenium & 4 & 0 & 0 & ug/L & 3 & 0 & $0-1$ & ug/L & 3 & 0 & 0 & ug/g \\
\hline Strontium & 4 & 30 & $20-50$ & $\mathrm{ug} / \mathrm{L}$ & 3 & 20 & $10-30$ & $\mathrm{ug} / \mathrm{L}$ & 1 & 10 & 10 & $\mathrm{ug} / \mathrm{g}$ \\
\hline Zinc & 4 & 10 & $0-10$ & ug/L & 2 & 10 & $0-20$ & ug/L & 3 & 10 & $10-20$ & $u g / g$ \\
\hline
\end{tabular}

1/ Median value 
Table 9.--Summary of selected chemical and physical characteristics of water at site 2 (Dry Branch near Samantha)

\begin{tabular}{|c|c|c|c|c|}
\hline Property & $\begin{array}{c}\text { Number } \\
\text { of } \\
\text { analyses } \\
\end{array}$ & Mean & Range & Units \\
\hline Di scharge. & 35 & 0.42 & $0.01-2.3$ & $\mathrm{~m}^{3} / \mathrm{s}$ \\
\hline Specific conductance (at $\left.25^{\circ} \mathrm{C}\right) \ldots \ldots \ldots \ldots$ & 33 & 22 & $15-43$ & umhos/cm \\
\hline pH. $\ldots \ldots \ldots \ldots \ldots \ldots \ldots, \ldots \ldots \ldots \ldots \ldots$ & 23 & $1 / 6.3$ & $4.8-7.2$ & units \\
\hline Temperature $\ldots \ldots \ldots \ldots \ldots \ldots \ldots \ldots \ldots \ldots$ & 27 & -12.5 & $3.0-21.5$ & ${ }^{\circ} \mathrm{C}$ \\
\hline 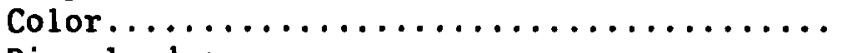 & 4 & 18 & $13-30$ & units \\
\hline Dissolved oxygen...................... & 10 & 9.9 & $7.6-12.5$ & $\mathrm{mg} / \mathrm{L}$ \\
\hline Hardness $\left(a \mathrm{CaCO}_{3}\right) \ldots \ldots \ldots \ldots \ldots \ldots \ldots \ldots \ldots \ldots$ & 12 & 5 & 2-8 & $\mathrm{mg} / \mathrm{L}$ \\
\hline Noncarbonate hardness. . . . . . . . . . . . . . & 9 & 0 & $0-2$ & $\mathrm{mg} / \mathrm{L}$ \\
\hline Acidity as $\mathrm{H}^{+} \ldots \ldots \ldots \ldots \ldots \ldots \ldots \ldots \ldots \ldots$ & 13 & .0 & $.0-.1$ & $\mathrm{mg} / \mathrm{L}$ \\
\hline Acidity as $\mathrm{CaCO}_{3} \ldots \ldots \ldots \ldots \ldots \ldots \ldots \ldots \ldots$ & 13 & .4 & $.0-5.0$ & $\mathrm{mg} / \mathrm{L}$ \\
\hline Calcium (Ca), dìssolved.................. & 12 & 1.0 & $.2-1.6$ & $\mathrm{mg} / \mathrm{L}$ \\
\hline Magnesium $\left(M_{g}\right)$, dissolved $\ldots \ldots \ldots \ldots \ldots \ldots$ & 12 & .7 & $.4-1.0$ & $\mathrm{mg} / \mathrm{L}$ \\
\hline Sodium $(\mathrm{Na})$, dissolved $\ldots \ldots \ldots \ldots \ldots \ldots \ldots$ & 11 & 1.4 & $1.2-1.7$ & $\mathrm{mg} / \mathrm{L}$ \\
\hline Percent sodium...................... & 11 & 33 & $24-46$ & $\%$ \\
\hline Sodium-adsorption ratio................. & 11 & .3 & $.2-.4$ & $-\cdots-$ \\
\hline Potassium $(K)$, dissolved $\ldots \ldots \ldots \ldots \ldots \ldots$ & 11 & .8 & $.6-1.1$ & $\mathrm{mg} / \mathrm{L}$ \\
\hline Bicarbonate $\left(\mathrm{HCO}_{3}\right) \ldots \ldots \ldots \ldots \ldots \ldots \ldots \ldots$ & 19 & 8 & $2-14$ & $\mathbf{m g} / \mathrm{L}$ \\
\hline Carbon dioxide $\left(\mathrm{CO}_{2}\right) \ldots \ldots \ldots \ldots \ldots \ldots \ldots$ & 19 & 21 & $.8-76$ & $\mathrm{mg} / \mathrm{L}$ \\
\hline Carbonate $\left(\mathrm{CO}_{3}\right), \ldots \ldots \ldots \ldots \ldots \ldots \ldots \ldots$ & 19 & 0 & 0 & $\mathrm{mg} / \mathrm{L}$ \\
\hline Sulfate $\left(\mathrm{SO}_{4}\right)$, dissolved $\ldots \ldots \ldots \ldots \ldots \ldots \ldots$ & 22 & 3.2 & $2.3-4.2$ & $\mathrm{mg} / \mathrm{L}$ \\
\hline Chloride $(\mathrm{Cl})$, dissolved................ & 4 & 1.7 & $1.3-2.0$ & $\mathrm{mg} / \mathrm{L}$ \\
\hline Fluoride $(F)$, dissolved $\ldots \ldots \ldots \ldots \ldots \ldots \ldots$ & 4 & .0 & $.0-.1$ & $\mathrm{mg} / \mathrm{L}$ \\
\hline Silica $\left(\mathrm{SiO}_{2}\right)$, dissolved $\ldots \ldots \ldots \ldots \ldots \ldots \ldots$ & 4 & 8.7 & $7.6-9.8$ & $\mathrm{mg} / \mathrm{L}$ \\
\hline Dissolved solids (sum of constituents)..... & 3 & 21 & $17-26$ & $\mathrm{mg} / \mathrm{L}$ \\
\hline Total nitrate $(\mathrm{N}) \ldots \ldots \ldots \ldots \ldots \ldots \ldots \ldots$ & 4 & .01 & $.00-.02$ & $\mathrm{mg} / \mathrm{L}$ \\
\hline Total nitrite $(\mathrm{N}) \ldots \ldots \ldots \ldots \ldots \ldots \ldots \ldots \ldots$ & 4 & .00 & .00 & $\mathrm{mg} / \mathrm{L}$ \\
\hline Total Kjeldahl nitrogen $(N) \ldots \ldots \ldots \ldots \ldots$ & 4 & .11 & $.08-.16$ & $\mathbf{m g} / \mathrm{L}$ \\
\hline Total nitrogen $(N) \ldots \ldots \ldots \ldots \ldots \ldots \ldots \ldots$ & 4 & .12 & $.09-.17$ & $\mathrm{mg} / \mathrm{L}$ \\
\hline Total nitrogen $\left(\mathrm{NO}_{3}\right) \ldots \ldots \ldots \ldots \ldots \ldots \ldots$ & 3 & .59 & $.44-.75$ & $\mathrm{mg} / \mathrm{L}$ \\
\hline Total phosphorus $(\widetilde{P}) \ldots \ldots \ldots \ldots \ldots \ldots \ldots$ & 4 & .01 & $.00-.02$ & $\mathrm{mg} / \mathrm{L}$ \\
\hline Total orthophorus phosphorus (P) $\ldots \ldots \ldots \ldots$ & 4 & .00 & .00 & $\mathrm{mg} / \mathrm{L}$ \\
\hline Total organic carbon (c) $\ldots \ldots \ldots \ldots \ldots \ldots$ & 4 & 5.0 & $.6-8.8$ & $\mathrm{mg} / \mathrm{L}$ \\
\hline Total inorganic carbon (c) $\ldots \ldots \ldots \ldots \ldots \ldots$ & 3 & 9.1 & $6.5-13$ & $\mathrm{mg} / \mathrm{L}$ \\
\hline Phenols $\ldots \ldots \ldots \ldots \ldots \ldots \ldots \ldots \ldots \ldots \ldots \ldots$ & 2 & 1 & $0-2$ & ug/L \\
\hline Alpha, gross dissolved as $U$ natural........ & 3 & .4 & $.4-.5$ & ug/L \\
\hline $\begin{array}{l}\text { Beta, gross dissolved as } \mathrm{Cs}-137 \ldots \ldots \ldots \ldots \\
\text { Beta, gross dissolved as strontium/ }\end{array}$ & 3 & 1.2 & $.6-2.0$ & $\mathrm{PC} / \mathrm{L}$ \\
\hline yetrium $-90 \ldots \ldots \ldots \ldots \ldots \ldots \ldots \ldots \ldots$ & 3 & 1.1 & $.6-1.6$ & $\mathrm{PC} / \mathrm{L}$ \\
\hline Radium-226, dissolved, Radon method.. & 3 & .05 & $.05-.06$ & $\mathrm{PC} / \mathrm{L}$ \\
\hline Uranium, natural dissolved (U) & 2 & .0 & .0 & ug/L \\
\hline
\end{tabular}

\begin{tabular}{|c|c|c|c|c|c|c|c|c|c|c|c|c|}
\hline \multirow[b]{2}{*}{ Property } & \multicolumn{4}{|c|}{ Dissolved } & \multicolumn{4}{|c|}{$\begin{array}{c}\text { Total recoverable in a } \\
\text { water-suspended sediment solution }\end{array}$} & \multicolumn{4}{|c|}{ Recoverable from bottom material } \\
\hline & $\begin{array}{c}\text { Nunber } \\
\text { of } \\
\text { analyses } \\
\end{array}$ & Mean & Range & Units & $\begin{array}{c}\begin{array}{c}\text { Number } \\
\text { of } \\
\text { analyses }\end{array} \\
\end{array}$ & Mean & Range & Units & $\begin{array}{c}\text { Number } \\
\text { of } \\
\text { analyses } \\
\end{array}$ & Mean & Range & Units \\
\hline Arsenic & 4 & 1 & $0-1$ & ug/L & 3 & 1 & $0-1$ & ug/L & 3 & 1 & $0-3$ & $\mathrm{ug} / \mathrm{g}$ \\
\hline Boron & 4 & 10 & $0-10$ & ug/L & 3 & 10 & $0-20$ & ug/L & 3 & 0 & 0 & $\mathrm{ug} / \mathrm{g}$ \\
\hline Cadmium & 4 & 1 & $0-2$ & ug/L & 3 & 10 & 10 & ug/L & 3 & $<10$ & $<10$ & $\mathrm{ug} / \mathrm{g}$ \\
\hline Iron & 13 & 40 & $10-90$ & ug/L & 11 & 1800 & $300-11000$ & ug/L & 3 & 7700 & $1100-15000$ & ug/g \\
\hline Lead & 4 & 2 & $0-7$ & ug/L & 3 & 10 & 10 & $\mathrm{ug} / \mathrm{L}$ & 3 & $<10$ & $<10$ & $\mathrm{ug} / \mathrm{g}$ \\
\hline Lithium & 4 & 0 & 0 & $\mathrm{ug} / \mathrm{L}$ & 3 & 0 & 0 & ug/L &.-- &.-- & $\ldots$ & $\ldots$ \\
\hline Manganese & 10 & 17 & $0-50$ & $\mathrm{ug} / \mathrm{L}$ & 10 & 57 & $10-160$ & ug/L & 2 & 320 & $290-350$ & $\mathrm{ug} / \mathrm{g}$ \\
\hline Mercury & 3 & .0 & $.0-.5$ & $\mathrm{ug} / \mathrm{L}$ & 2 & .5 & $.0-.5$ & ug/L & 3 & .0 & .0 & $\mathrm{ug} / \mathrm{g}$ \\
\hline Selenium & 4 & 0 & 0 & $\mathrm{ug} / \mathrm{L}$ & 3 & 0 & $0-1$ & ug/L & 3 & 0 & $.0-1$ & ug/g \\
\hline Strontium & 4 & 50 & $20-80$ & $\mathrm{ug} / \mathrm{L}$ & 3 & 50 & $20-80$ & ug/L & 2 & 10 & 10 & $\mathrm{ug} / \mathrm{g}$ \\
\hline
\end{tabular}

1/ Median value 
Table 10.--Sumnary of selected chemical and physical characteristics of water at site 3 (Blue Creek near Oakman)

\begin{tabular}{|c|c|c|c|c|}
\hline Property & $\begin{array}{c}\text { Number } \\
\text { of } \\
\text { analyses }\end{array}$ & Mean & Range & Units \\
\hline Discharge.................. & 65 & 4.0 & $0.01-19$ & $\mathrm{~m}^{3} / \mathrm{s}$ \\
\hline Specific conductance $\left(\right.$ at $\left.25^{\circ} \mathrm{C}\right) \ldots \ldots \ldots \ldots$ & 37 & 79 & $18-410$ & unhos/cm \\
\hline 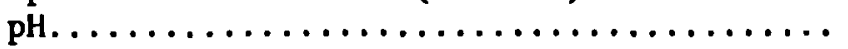 & 34 & $1 / 6.6$ & $5.2-7.3$ & units \\
\hline Temperature $\ldots \ldots \ldots \ldots \ldots \ldots \ldots \ldots \ldots$ & 36 & 15.0 & $1.5-29$ & ${ }^{\circ} \mathrm{C}$ \\
\hline 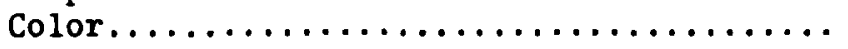 & 5 & 26 & $10-40$ & units \\
\hline Dissolved oxygen................... & 17 & 9.0 & $5.3-12.9$ & $\mathbf{m g} / \mathrm{L}$ \\
\hline Hardness $\left(a s \mathrm{CaCO}_{3}\right) \ldots \ldots \ldots \ldots \ldots \ldots$ & 15 & 18 & $4-75$ & $\mathrm{mg} / \mathrm{L}$ \\
\hline Noncarbonate hardness................. & 14 & 13 & $0-57$ & $\mathrm{mg} / \mathrm{L}$ \\
\hline Acidity as $\mathrm{H}^{+} \ldots \ldots \ldots \ldots \ldots \ldots \ldots \ldots$ & 17 & .0 & $.0-.1$ & $\mathrm{mg} / \mathrm{L}$ \\
\hline Acidity as $\mathrm{CaCO}_{3} \ldots \ldots \ldots \ldots \ldots \ldots \ldots \ldots$ & 17 & .6 & $.0-5.0$ & $\mathrm{mg} / \mathrm{L}$ \\
\hline 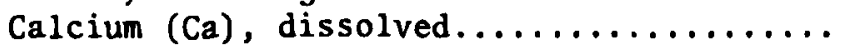 & 15 & 3.1 & $.5-13$ & $\mathbf{m g} / \mathrm{L}$ \\
\hline Magnesium $(\mathrm{Mg})$, dissolved............... & 15 & 2.6 & $.6-11$ & $\mathrm{mg} / \mathrm{L}$ \\
\hline 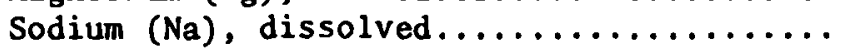 & 13 & 2.3 & $.9-6.3$ & $\mathrm{mg} / \mathrm{L}$ \\
\hline 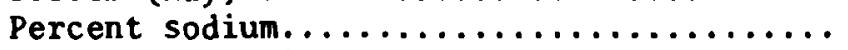 & 13 & 24 & $10-39$ & $\%$ \\
\hline Sodium-adsorption ratio............... & 13 & .2 & $.1-.4$ & $-\ldots-.-1$ \\
\hline 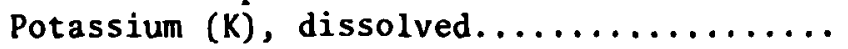 & 13 & 1.2 & $.7-2.2$ & $\mathrm{mg} / \mathrm{L}$ \\
\hline Bicarbonate $\left(\mathrm{HCO}_{3}\right) \ldots \ldots \ldots \ldots \ldots \ldots \ldots$ & 29 & 11 & $2-35$ & $\mathrm{mg} / \mathrm{L}$ \\
\hline Carbon dioxide $\left(\mathrm{CO}_{2}\right) \ldots \ldots \ldots \ldots \ldots \ldots$ & 29 & 12 & $1-89$ & $\mathbf{m g} / \mathrm{L}$ \\
\hline Carbonate $\left(\mathrm{CO}_{3}\right) \ldots \ldots \ldots \ldots \ldots \ldots \ldots$ & 27 & 0 & 0 & $m g / L$ \\
\hline Sulfate $\left(\mathrm{SO}_{4}\right)$, dissolved.............. & 29 & 20 & $4.0-110$ & $\mathrm{mg} / \mathrm{L}$ \\
\hline 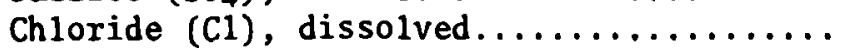 & 10 & 1.9 & $1.0-4.4$ & $\mathrm{mg} / \mathrm{L}$ \\
\hline Fluoride $(F)$, dissolved............... & 7 & .0 & $.0-.1$ & $\mathrm{mg} / \mathrm{L}$ \\
\hline 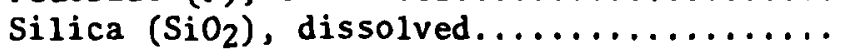 & 7 & 6.7 & $4.0-8.5$ & $\mathrm{mg} / \mathrm{L}$ \\
\hline Dissolved solids (sun of constituents)..... & 7 & 53 & $22-112$ & $\mathrm{mg} / \mathrm{L}$ \\
\hline Total nitrate $(N) \ldots \ldots \ldots \ldots \ldots \ldots$ & 5 & .03 & $.00-.07$ & $\mathrm{mg} / \mathrm{L}$ \\
\hline Total nitrite $(\mathrm{N}) \ldots \ldots \ldots \ldots \ldots \ldots$ & 5 & .00 & $.00-.01$ & $\mathrm{mg} / \mathrm{L}$ \\
\hline Total Kjeldahl nitrogen $(\mathrm{N}) \ldots \ldots \ldots \ldots \ldots$ & 5 & .24 & $.10-.59$ & $\mathrm{mg} / \mathrm{L}$ \\
\hline Total nitrogen $(N) \ldots \ldots \ldots \ldots \ldots \ldots \ldots$ & 5 & .26 & $.14-.64$ & $m g / L$ \\
\hline Total nitrogen $\left(\mathrm{NO}_{3}\right) \ldots \ldots \ldots \ldots \ldots \ldots$ & 3 & 1.4 & $.62-2.8$ & $\mathrm{mg} / \mathrm{L}$ \\
\hline 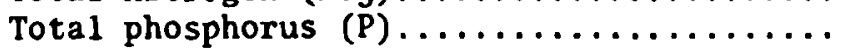 & 5 & .01 & $.01-.02$ & $\mathrm{mg} / \mathrm{L}$ \\
\hline Total orthophorus phosphorus (P) ......... & 5 & .00 & .00 & $\mathrm{mg} / \mathrm{L}$ \\
\hline Total organic carbon (C) .............. & 2 & 8.8 & $6.5-11$ & $\mathrm{mg} / \mathrm{L}$ \\
\hline Total inorganic carbon (C) ............. & 2 & 8.6 & $6.1-11$ & $\mathrm{mg} / \mathrm{L}$ \\
\hline 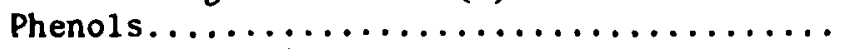 & 2 & 0 & 0 & $u g / L$ \\
\hline Alpha, gross dissolved as $U$ natural....... & 1 & .6 & .6 & ug/L \\
\hline $\begin{array}{l}\text { Beta, gross dissolved as Cs-137.......... } \\
\text { Beta, gross dissolved as strontium/ }\end{array}$ & 3 & 2.0 & $.7-2.7$ & $\mathrm{PC} / \mathrm{L}$ \\
\hline 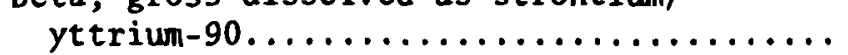 & 3 & 1.8 & $.7-2.4$ & $\mathrm{PC} / \mathrm{L}$ \\
\hline Radium-226, dissolved, Radon method.... & 3 & .04 & $.03-.05$ & $\mathrm{PC} / \overline{\mathrm{L}}$ \\
\hline Uranium, natural dissolved (U) ........... & 3 & .0 & $.0-.1$ & $u g / L$ \\
\hline
\end{tabular}

\begin{tabular}{|c|c|c|c|c|c|c|c|c|c|c|c|c|}
\hline \multirow[b]{2}{*}{ Property } & \multicolumn{4}{|c|}{ Dissolved } & \multicolumn{4}{|c|}{$\begin{array}{l}\text { Total recoverable in a } \\
\text { ater-suspended sediment solution }\end{array}$} & \multicolumn{2}{|c|}{ Recoverable from } & \multicolumn{2}{|c|}{ bottom material } \\
\hline & $\begin{array}{c}\text { Number } \\
\text { of } \\
\text { analyses } \\
\end{array}$ & Mean & Range & Units & $\begin{array}{c}\begin{array}{c}\text { Number } \\
\text { of } \\
\text { analyses }\end{array} \\
\end{array}$ & Mean & Range & Units & $\begin{array}{c}\text { Number } \\
\text { of } \\
\text { analyses } \\
\end{array}$ & Mean & Range & Units \\
\hline Aluminum & 13 & 50 & $10-140$ & $\mathrm{ug} / \mathrm{L}$ & 10 & 1400 & $70-7600$ & ug/L & 2 & 800 & $500-1200$ & $\mathrm{ug} / \mathrm{g}$ \\
\hline Arsenic & 2 & 1 & $0-1$ & ug/L & 1 & 0 & 0 & $u g / L$ & 2 & 8 & $0-17$ & $\mathrm{ug} / \mathrm{g}$ \\
\hline Boron & 2 & 15 & $0-30$ & $\mathrm{ug} / \mathrm{L}$ & 1 & 0 & 0 & ug/L & 2 & 0 & 0 & $\mathrm{ug} / \mathrm{g}$ \\
\hline Cadmium & 2 & 1 & $0-1$ & $\mathrm{ug} / \mathrm{L}$ & 1 & 10 & 10 & $\mathrm{ug} / \mathrm{L}$ & 2 & $<10$ & $<10$ & ug/g \\
\hline Chromium & 2 & 1 & $0-3$ & ug/L & 1 & 10 & 10 & ug/L & 1 & 10 & 10 & $\mathrm{ug} / \mathrm{g}$ \\
\hline Cobalt & 2 & 0 & 0 & ug/L & 1 & 0 & 0 & $\mathrm{ug} / \mathrm{L}$ & 2 & $<10$ & $<10$ & $\mathrm{ug} / \mathrm{g}$ \\
\hline Copper & 2 & 1 & $0-1$ & ug/L & 1 & 10 & 10 & $\mathrm{ug} / \mathrm{L}$ & 2 & $<10$ & $<10$ & ug/g \\
\hline Iron & 13 & 90 & $10-600$ & ug/L & 11 & 2100 & $200-12000$ & ug/L & 2 & 2600 & $900-4300$ & $\mathrm{ug} / \mathrm{g}$ \\
\hline Lead & 2 & 8 & $2-10$ & $\mathrm{ug} / \mathrm{L}$ & 1 & 40 & 40 & $u g / L$ & 2 & $<10$ & $<10$ & $u g / g$ \\
\hline Lithium & 2 & 0 & 0 & ug/L & 1 & 0 & 0 & $u g / L$ & 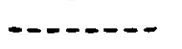 & ---- & 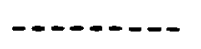 & $\ldots$ \\
\hline Manganese & 9 & 51 & $20-90$ & ug/L & 10 & 130 & $20-580$ & $\mathrm{ug} / \mathrm{L}$ & 2 & 300 & $150-460$ & ug/g \\
\hline Mercury & 2 & .5 & $.0-.5$ & $\mathrm{ug} / \mathrm{L}$ & 1 & .5 & .5 & ug/L & 2 & 0 & 0 & ug/g \\
\hline Selenium & 2 & 1 & $0-1$ & $\mathrm{ug} / \mathrm{L}$ & 1 & 1 & 1 & $u g / L$ & 2 & 0 & 0 & $\mathrm{ug} / \mathrm{g}$ \\
\hline Strontium & 2 & 80 & $50-100$ & ug/L & 1 & 90 & 90 & ug/L & 2 & 10 & 10 & ug/g \\
\hline Zinc & 2 & 10 & 10 & ug/L & 1 & 20 & 20 & $u g / L$ & 2 & 20 & $10-20$ & $\mathrm{ug} / \mathrm{g}$ \\
\hline
\end{tabular}

1/ Median value 
Table 11.--Sumnary of selected chemical and physical characteristics of water at site 4 (Turkey Creek near Tuscaloosa)

\begin{tabular}{|c|c|c|c|c|}
\hline Property & $\begin{array}{c}\text { Number } \\
\text { of } \\
\text { analyses }\end{array}$ & Mean & Range & Units \\
\hline Discharge.................... & 34 & 1.1 & $0.03-11$ & $\mathrm{~m}^{3} / \mathrm{s}$ \\
\hline Specific conductance $\left(\right.$ at $\left.25^{\circ} \mathrm{C}\right) \ldots \ldots \ldots \ldots$ & 31 & 17 & $12-31$ & umhos/cm \\
\hline 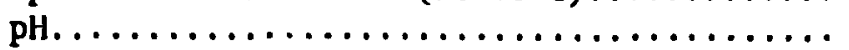 & 28 & $1 / 6.3$ & $5.0-7.3$ & units \\
\hline 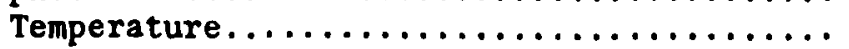 & 34 & 14.5 & $2.0-26.0$ & ${ }^{\circ} \mathrm{C}$ \\
\hline 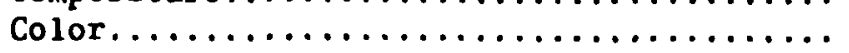 & 5 & 33 & $20-55$ & units \\
\hline Dissolved oxygen................... & 16 & 9.6 & $7.3-12.7$ & $\mathrm{mg} / \mathrm{L}$ \\
\hline Hardness $\left(a s \mathrm{CaCO}_{3}\right) \ldots \ldots \ldots \ldots \ldots \ldots \ldots$ & 10 & 5 & $2-8$ & $\mathrm{mg} / \mathrm{L}$ \\
\hline Noncarbonate hardness.................. & 10 & 1 & $0-2$ & $\mathrm{mg} / \mathrm{L}$ \\
\hline Acidity as $\mathrm{H}^{+} \ldots \ldots \ldots \ldots \ldots \ldots \ldots \ldots$ & 16 & .1 & $.0-1.0$ & $\mathrm{mg} / \mathrm{L}$ \\
\hline Acidity as $\mathrm{CaCO}_{3} \ldots \ldots \ldots \ldots \ldots \ldots \ldots \ldots$ & 15 & .7 & $.0-5.0$ & $\mathrm{mg} / \mathrm{L}$ \\
\hline 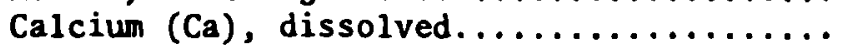 & 10 & 1.1 & $.1-2.2$ & $\mathrm{mg} / \mathrm{L}$ \\
\hline Magnesium $(\mathrm{Mg})$, dissolved................ & 10 & .5 & $.4-.9$ & $m g / L$ \\
\hline Sodium $(\mathrm{Na})$, dissolved................. & 8 & 1.3 & $.9-2.0$ & $\mathrm{mg} / \mathrm{L}$ \\
\hline 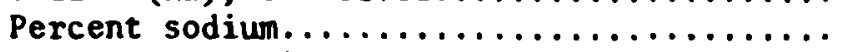 & 8 & 35 & $28-51$ & $\%$ \\
\hline Sodium-adsorption ratio................ & 8 & .3 & $.2-.4$ & 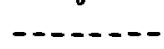 \\
\hline 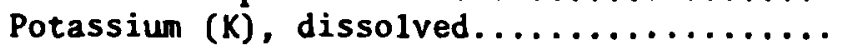 & 8 & .6 & $.4-.8$ & $\mathrm{mg} / \mathrm{L}$ \\
\hline Bicarbonate $\left(\mathrm{HCO}_{3}\right) \ldots \ldots \ldots \ldots \ldots \ldots \ldots \ldots$ & 26 & 6 & $0-13$ & $\mathrm{mg} / \mathrm{L}$ \\
\hline Carbon dioxide $\left(\mathrm{CO}_{2}\right) \ldots \ldots \ldots \ldots \ldots \ldots \ldots$ & 24 & 12 & $1-80$ & $\mathrm{mg} / \mathrm{L}$ \\
\hline Carbonate $\left(\mathrm{CO}_{3}\right) \ldots \ldots \ldots \ldots \ldots \ldots \ldots \ldots$ & 25 & 0 & 0 & $\mathrm{mg} / \mathrm{L}$ \\
\hline Sulfate $\left(\mathrm{SO}_{4}\right)$, dissolved.............. & 24 & 2.6 & $1.2-4.9$ & $\mathrm{mg} / \mathrm{L}$ \\
\hline Chloride (Cl), dissolved............... & 5 & 1.6 & $1.4-1.7$ & $\mathrm{mg} / \mathrm{L}$ \\
\hline Fluoride (F), dissolved............... & 5 & .0 & .0 & $\mathrm{mg} / \mathrm{L}$ \\
\hline 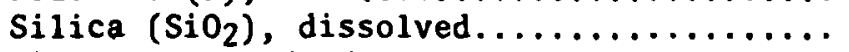 & 5 & 6.4 & $5.6-7.4$ & $\mathrm{mg} / \mathrm{L}$ \\
\hline Dissolved solids (sum of constituents)..... & 5 & 16 & $12-22$ & $m g / L$ \\
\hline Total nitrate $(\mathrm{N}) \ldots \ldots \ldots \ldots \ldots \ldots \ldots$ & 5 & .02 & $.01-.04$ & $\mathrm{mg} / \mathrm{L}$ \\
\hline Total nitrite (N) $\ldots \ldots \ldots \ldots \ldots \ldots$ & 5 & .00 & .00 & $\mathrm{mg} / \mathrm{L}$ \\
\hline Total Kjeldahl nitrogen $(N) \ldots \ldots \ldots \ldots \ldots$ & 5 & .16 & $.09-.32$ & $\mathrm{mg} / \mathrm{L}$ \\
\hline Total nitrogen $(N) \ldots \ldots \ldots \ldots \ldots \ldots$ & 5 & .18 & $.10-.36$ & $\mathrm{mg} / \mathrm{L}$ \\
\hline Total nitrogen $\left(\mathrm{NO}_{3}\right) \ldots \ldots \ldots \ldots \ldots \ldots$ & 4 & .82 & $.44-1.6$ & $\mathrm{mg} / \mathrm{L}$ \\
\hline Total phosphorus $(P) \ldots \ldots \ldots \ldots \ldots \ldots \ldots \ldots$ & 5 & .01 & $.00-.01$ & $\mathrm{mg} / \mathrm{L}$ \\
\hline Total orthophorus phosphorus (P) ........ & 5 & .00 & .00 & $\mathrm{mg} / \mathrm{L}$ \\
\hline 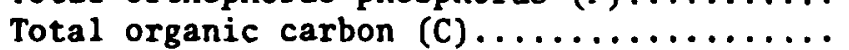 & 4 & 6.8 & $2.2-11$ & $\mathrm{mg} / \mathrm{L}$ \\
\hline Total inorganic carbon (c) .............. & 3 & 6.7 & $4.4-8.5$ & $\mathrm{mg} / \mathrm{L}$ \\
\hline Phenols........................ & 3 & 0 & 0 & ug/L \\
\hline Alpha, gross dissolved as $U$ natural........ & 4 & .2 & $.0-.5$ & ug/L \\
\hline $\begin{array}{l}\text { Beta, gross dissolved as Cs }-137 \ldots \ldots \ldots \ldots \ldots \\
\text { Beta, gross dissolved as strontium/ }\end{array}$ & 4 & .9 & $.5-1.4$ & $\mathrm{PC} / \mathrm{L}$ \\
\hline 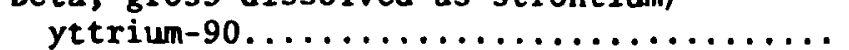 & 4 & .8 & $.5-1.2$ & $\mathrm{PC} / \mathrm{L}$ \\
\hline Radium-226, dissolved, Radon method........ & 4 & .07 & $.04-.1$ & $\mathrm{PC} / \mathrm{L}$ \\
\hline Uranium, natural dissolved (U).......... & 2 & .0 & .0 & $\mathrm{ug} / \mathrm{L}$ \\
\hline
\end{tabular}

\begin{tabular}{|c|c|c|c|c|c|c|c|c|c|c|c|c|}
\hline \multirow[b]{2}{*}{ Property } & \multicolumn{4}{|c|}{ Dissolved } & \multicolumn{4}{|c|}{ Total recoverable in a } & \multicolumn{2}{|c|}{ Recoverable from } & bottom & \multirow[b]{2}{*}{ Units } \\
\hline & $\begin{array}{c}\text { Number } \\
\text { of . } \\
\text { analyses }\end{array}$ & Mean. & Range & Units & $\begin{array}{l}\text { Number } \\
\text { of } \\
\text { analyses }\end{array}$ & Mean & Range & Units & $\begin{array}{c}\text { Number } \\
\text { of } \\
\text { analyses }\end{array}$ & Mean & Range & \\
\hline Aluminum & 30 & 30 & $0-80$ & ug/L & 7 & 700 & $40-2300$ & $u g / L$ & 4 & 200 & $10-400$ & ug/g \\
\hline Arsenic & 4 & 1 & $0-1$ & $\mathrm{ug} / \mathrm{L}$ & 2 & 1 & $0-1$ & $u g / L$ & 4 & 0 & 0 & ug/g \\
\hline Boron & 4 & 10 & $0-20$ & $u g / L$ & 2 & 0 & 0 & $u g / L$ & 4 & 0 & 0 & $\mathrm{ug} / \mathrm{g}$ \\
\hline Cadmium & 4 & 1 & $0-1$ & ug/L & 3 & 10 & 10 & $u g / L$ & 4 & $<10$ & $<10$ & $\mathrm{ug} / \mathrm{g}$ \\
\hline Chromium & 4 & 1 & $0-2$ & ug/L & 1 & 10 & 10 & $u g / L$ & 4 & $<10$ & $<10$ & $\mathrm{ug} / \mathrm{g}$ \\
\hline Cobalt & 4 & 0 & 0 & $\mathrm{ug} / \mathrm{L}$ & 3 & 0 & 0 & ug/L & 4 & $<10$ & $<10$ & $\mathrm{ug} / \mathrm{g}$ \\
\hline Copper & 4 & 1 & $0-3$ & ug/L & 3 & 10 & 10 & $\mathrm{ug} / \mathrm{L}$ & 1 & 20 & 20 & $\mathrm{ug} / \mathrm{g}$ \\
\hline Iron & 11 & 60 & $20-160$ & $u g / L$ & 8 & 1600 & $400-4400$ & ug/L & 4 & 900 & $500-1500$ & $\mathrm{ug} / \mathrm{g}$ \\
\hline Lead & 4 & 6 & $0-18$ & $u g / L$ & 2 & 10 & 10 & $u g / L$ & 4 & $<10$ & $<10$ & $\mathrm{ug} / \mathrm{g}$ \\
\hline Lithiun & 4 & 0 & 0 & $\mathrm{ug} / \mathrm{L}$ & 3 & 0 & 0 & $u g / L$ & 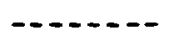 & $-\cdots$ & -------- & $\ldots$ \\
\hline Manganese & 6 & 22 & $10-40$ & ug/L & 6 & 65 & $10-170$ & ug/L & 3 & 50 & $30-70$ & $u g / g$ \\
\hline Mercury & 4 & .0 & $.0-.5$ & ug/L & 3 & .0 & $.0-.5$ & $u g / L$ & 4 & 0 & 0 & $\mathrm{ug} / \mathrm{g}$ \\
\hline Seleniun & 4 & 0 & 0 & ug/L & 3 & 1 & $0-1$ & $u g / L$ & 4 & 0 & 0 & ug/g \\
\hline Strontium & 4 & 20 & $0-40$ & $u g / L$ & 3 & 20 & $20-30$ & $u g / L$ & 2 & 10 & 10 & $\mathrm{ug} / \mathrm{g}$ \\
\hline Zinc & 4 & 10 & $0-10$ & ug/L & 3 & 10 & $10-20$ & $u g / L$ & 2 & 10 & $3-10$ & $\mathrm{ug} / \mathrm{g}$ \\
\hline
\end{tabular}

1) Median value 
Table 12.--Summary of selected chemical and physical characteristics of water at site 5 (Yellow Creek above Northport)

\begin{tabular}{|c|c|c|c|c|}
\hline Property & $\begin{array}{c}\text { Number } \\
\text { of } \\
\text { analyses }\end{array}$ & Mean & Range & Units \\
\hline Discharge.. & 25 & 0.31 & $0.08-1.9$ & $\mathrm{~m}^{3} / \mathrm{s}$ \\
\hline Specific conductance $\left(\right.$ at $\left.25^{\circ} \mathrm{C}\right) \ldots \ldots \ldots \ldots$ & 26 & & $8-18$ & umhos $/ \mathrm{cm}$ \\
\hline 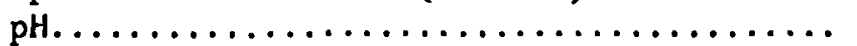 & 24 & $1 / 5.9$ & $4.9-6.7$ & units \\
\hline Temperature $\ldots \ldots \ldots \ldots \ldots \ldots \ldots \ldots \ldots$ & 27 & -15.5 & $3.5-23.5$ & ${ }^{\circ} \mathrm{C}$ \\
\hline Color $\ldots \ldots \ldots \ldots \ldots, \ldots, \ldots, \ldots, \ldots, \ldots$ & 5 & 40 & $16-55$ & units \\
\hline Dissolved oxygen.$\ldots \ldots \ldots \ldots \ldots \ldots \ldots \ldots$ & 14 & 8.8 & $6.9-12.0$ & $\mathbf{m g} / \mathrm{L}$ \\
\hline Hardness $\left(\right.$ as $\left.\mathrm{CaCO}_{3}\right) \ldots \ldots \ldots \ldots \ldots \ldots \ldots \ldots$ & 9 & 3 & $2-4$ & $\mathrm{mg} / \mathrm{L}$ \\
\hline Noncarbonate hardness $\ldots \ldots \ldots \ldots \ldots \ldots \ldots \ldots$ & 8 & 1 & $0-2$ & $\mathrm{mg} / \mathrm{L}$ \\
\hline Acidity as $\mathrm{H}^{+} \ldots \ldots \ldots \ldots \ldots \ldots \ldots \ldots$ & 13 & 0 & $0-.1$ & $\mathrm{mg} / \mathrm{L}$ \\
\hline Acidity as $\mathrm{CaCO}_{3}, \ldots \ldots \ldots \ldots \ldots \ldots \ldots$ & 13 & .8 & $.0-5.0$ & $\mathrm{mg} / \mathrm{L}$ \\
\hline Calcium (Ca), dissolved.................. & 9 & .6 & $.4-1.1$ & $\mathrm{mg} / \mathrm{L}$ \\
\hline 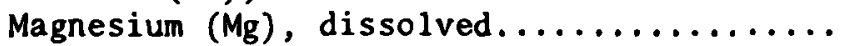 & 9 & .4 & $.1-.7$ & $\mathrm{mg} / \mathrm{L}$ \\
\hline 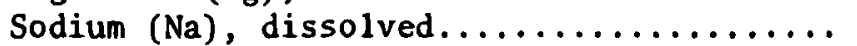 & 7 & 1.1 & $.8-1.7$ & $\mathrm{mg} / \mathrm{L}$ \\
\hline Percent sodium....................... & 7 & 42 & $35-55$ & $\%$ \\
\hline Sodium-adsorption ratio................ & 7 & .3 & $.2-.4$ & $-\ldots$ \\
\hline Potassium (K), dissolved.. & 7 & .4 & $.2-.5$ & $\mathrm{mg} / \mathrm{L}$ \\
\hline Bicarbonate $\left(\mathrm{HCO}_{3}\right) \ldots \ldots \ldots \ldots \ldots \ldots \ldots \ldots$ & 20 & 5 & $2-12$ & $\mathrm{mg} / \mathrm{L}$ \\
\hline Carbon dioxide $\left(\mathrm{CO}_{2}\right) \ldots \ldots \ldots \ldots \ldots \ldots \ldots$ & 20 & 19 & $2-81$ & $\mathrm{mg} / \mathrm{L}$ \\
\hline Carbonate $\left(\mathrm{CO}_{3}\right) \ldots \ldots \ldots \ldots \ldots \ldots \ldots \ldots \ldots$ & 20 & 0 & 0 & $\mathrm{mg} / \mathrm{L}$ \\
\hline Sulfate $\left(\mathrm{SO}_{4}\right)$, dissolved $\ldots \ldots \ldots \ldots \ldots \ldots$ & 21 & 1.9 & $.9-3.7$ & $\mathrm{mg} / \mathrm{L}$ \\
\hline Chloride $(\mathrm{Cl})$, dissolved............... & 5 & 1.4 & $1.2-1.7$ & $\mathbf{m g} / \mathrm{L}$ \\
\hline 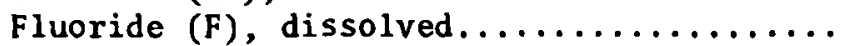 & 5 & .1 & $.0-.3$ & $\mathrm{mg} / \mathrm{L}$ \\
\hline Silica $\left(\mathrm{SiO}_{2}\right)$, dissolved............... & 5 & 5.5 & $4.8-6.1$ & $\mathrm{mg} / \mathrm{L}$ \\
\hline Dissolved solids (sum of constituents)..... & 4 & 12 & $12-13$ & $\mathrm{mg} / \mathrm{L}$ \\
\hline Total nitrate $(\mathrm{N}) \ldots \ldots \ldots \ldots \ldots \ldots \ldots \ldots$ & 5 & .01 & $.00-.01$ & $\mathrm{mg} / \mathrm{L}$ \\
\hline Total nitrite (N) $\ldots \ldots \ldots \ldots \ldots \ldots$ & 5 & .00 & .00 & $\mathrm{mg} / \mathrm{L}$ \\
\hline Total Kjeldahl nitrogen $(\mathrm{N}) \ldots \ldots \ldots \ldots \ldots$ & 5 & .16 & $.12-.22$ & $\mathrm{mg} / \mathrm{L}$ \\
\hline Total nitrogen $(\mathrm{N}) \ldots \ldots \ldots \ldots \ldots \ldots \ldots \ldots$ & 5 & .16 & $.13-.23$ & $\mathrm{mg} / \mathrm{L}$ \\
\hline Total nitrogen $\left(\mathrm{NO}_{3}\right) \ldots \ldots \ldots$ & 4 & .74 & $.58-1.0$ & $\mathrm{mg} / \mathrm{L}$ \\
\hline Total phosphorus (P) $\ldots \ldots \ldots \ldots \ldots$ & 5 & .01 & $.00-.01$ & $\mathrm{mg} / \mathrm{L}$ \\
\hline Total orthophorus phosphorus (P)... & 5 & .00 & .00 & $\mathrm{mg} / \mathrm{L}$ \\
\hline Total organic carbon (C) $\ldots \ldots \ldots \ldots \ldots \ldots$ & 5 & 6.8 & $2.6-12$ & $\mathrm{mg} / \mathrm{L}$ \\
\hline Total inorganic carbon (C)........ & 4 & 9.8 & $5.4-15$ & $\mathrm{mg} / \mathrm{L}$ \\
\hline Phenols............................ & 3 & 0 & 0 & ug/L \\
\hline Alpha, gross dissolved as $U$ natural....... & 5 & 1.4 & $.0-3.6$ & $\mathrm{ug} / \mathrm{L}$ \\
\hline Beta, gross dissolved as Cs $-137 \ldots .$. & 4 & .9 & $.4-1.2$ & $\mathrm{PC} / \mathrm{L}$ \\
\hline Beta, gross dissolved as strontium/ & & & & \\
\hline$y t \operatorname{trium}-90, \ldots \ldots \ldots \ldots \ldots \ldots \ldots \ldots \ldots$ & 4 & .8 & $.5-1.1$ & $\mathrm{PC} / \mathrm{L}$ \\
\hline Radium-226, dissolved, $R a$ & 4 & .08 & $.05-.1$ & $\mathrm{PC} / \mathrm{L}$ \\
\hline Uranium, natural dissolve & 1 & .0 & & \\
\hline
\end{tabular}

\begin{tabular}{|c|c|c|c|c|c|c|c|c|c|c|c|c|}
\hline \multirow[b]{2}{*}{ Property } & \multicolumn{4}{|c|}{ Dissolved } & \multicolumn{4}{|c|}{$\begin{array}{c}\text { Total recoverable in a } \\
\text { water-suspended sediment solution }\end{array}$} & \multicolumn{4}{|c|}{ Recoverable from bottom material } \\
\hline & $\begin{array}{c}\text { Number } \\
\text { of } \\
\text { analyses }\end{array}$ & Mean & Range & Units & $\begin{array}{c}\text { Number } \\
\text { of } \\
\text { analyses }\end{array}$ & Mean & Range & Units & $\begin{array}{c}\text { Number } \\
\text { of } \\
\text { analyses }\end{array}$ & Mean & Range & Units \\
\hline Aluminum & 7 & 30 & $10-60$ & ug/L & 5 & 100 & $20-200$ & ug/L & 4 & 200 & $10-300$ & $\mathrm{ug} / \mathrm{g}$ \\
\hline Arsenic & 5 & 1 & $0-1$ & ug/L & 4 & 1 & $0-2$ & $\mathrm{ug} / \mathrm{L}$ & 4 & 1 & $0-1$ & $\mathrm{ug} / \mathrm{g}$ \\
\hline Boron & 5 & 16 & $0-40$ & ug/L & 4 & 10 & $0-20$ & ug/L & 4 & 10 & $0-10$ & $\mathrm{ug} / \mathrm{g}$ \\
\hline Cadmium & 5 & 0 & 0 & ug/L & 4 & 10 & 10 & ug/L & 4 & $<10$ & $<10$ & $\mathrm{ug} / \mathrm{g}$ \\
\hline Chromium & 5 & 1 & $0-3$ & ug/L & 3 & 10 & 10 & ug/L & 1 & 10 & 10 & $\mathrm{ug} / \mathrm{g}$ \\
\hline Cobalt & 5 & 10 & 10 & $\mathrm{ug} / \mathrm{L}$ & 4 & 10 & 10 & ug/L & 4 & $<10$ & $<10$ & ug/g \\
\hline Copper & 5 & 1 & $0-2$ & ug/L & 4 & 10 & 10 & ug/L & 4 & $<10$ & $<10$ & $\begin{array}{l}\mathrm{ug} / \mathrm{g} \\
\mathrm{ug} / \mathrm{g}\end{array}$ \\
\hline Iron & 9 & 120 & $60-220$ & ug/L & 5 & 1500 & $450-3600$ & ug/L & 4 & 1100 & $640-1500$ & $\mathrm{ug} / \mathrm{B}$ \\
\hline Lead & 5 & 5 & $0-13$ & ug/L & 4 & 10 & $0-12$ & ug/L & 4 & $<10$ & $<10$ & ug/g \\
\hline Lithium & 5 & 0 & 0 & ug/L & 4 & 0 & 0 & ug/L & 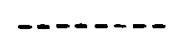 & -..- & 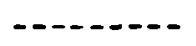 & $\cdots$ \\
\hline Manganese & 5 & 32 & $20-40$ & Ug/L & 4 & 48 & $30-100$ & $\mathrm{ug} / \mathrm{L}$ & 3 & 60 & $20-140$ & $u g / g$ \\
\hline Mercury & 4 & .0 & $.0-.5$ & ug/L & 3 & .0 & $.0-.5$ & ug/L & 4 & 0 & 0 & ug/g \\
\hline Selenium & 5 & 0 & 0 & ug/L & 4 & 1 & $0-1$ & ug/L & 4 & 0 & 0 & ug/g \\
\hline Strontium & 5 & 30 & $0-40$ & ug/L & 4 & 60 & $0-210$ & ug/L & 1 & 10 & 10 & ug/g \\
\hline Zine & 5 & 10 & $0-20$ & $u g / L$ & 4 & 20 & $10-20$ & ug/L & 3 & 90 & $2-270$ & $\mathrm{ug} / \mathrm{g}$ \\
\hline
\end{tabular}

1/ Median value 


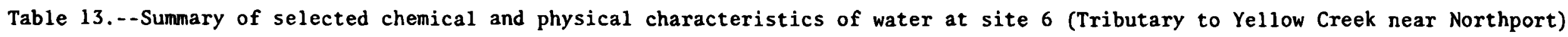

\begin{tabular}{|c|c|c|c|c|}
\hline Property & $\begin{array}{c}\text { Number } \\
\text { of } \\
\text { analyses } \\
\end{array}$ & Mean & Range & Units \\
\hline 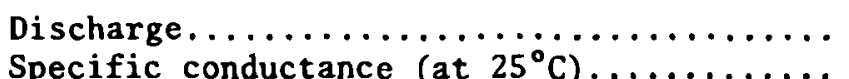 & $\begin{array}{l}18 \\
15\end{array}$ & 0.13 & $\begin{array}{c}0.03-0.35 \\
8-18\end{array}$ & $\mathrm{~m}^{3} / \mathrm{s}$ \\
\hline pH. & 13 & $1 / 6.0$ & $5.2-6.8$ & units \\
\hline 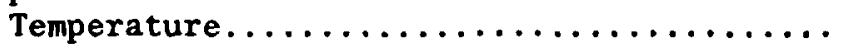 & 19 & 16.5 & $7.0-22.5$ & ${ }^{\circ} \mathrm{C}$ \\
\hline Color $\ldots \ldots \ldots \ldots \ldots \ldots \ldots \ldots \ldots \ldots \ldots$ & 2 & 32 & $10-55$ & units \\
\hline Dissolved oxygen.................... & 5 & 8.3 & $7.5-8.7$ & $\mathrm{mg} / \mathrm{L}$ \\
\hline Hardness $\left(a s \mathrm{CaCO}_{3}\right) \ldots \ldots \ldots \ldots \ldots \ldots$ & 5 & 2 & $1-4$ & $m g / L$ \\
\hline 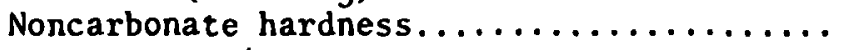 & 4 & 0 & 0 & $\mathrm{mg} / \mathrm{L}$ \\
\hline Acidity as $H^{+} \ldots \ldots \ldots \ldots \ldots \ldots \ldots \ldots$ & 7 & .1 & $.0-.4$ & $\mathrm{mg} / \mathrm{L}$ \\
\hline Acidity as $\mathrm{CaCO}_{3} \ldots \ldots \ldots \ldots \ldots \ldots \ldots$ & 7 & 2.9 & $.0-20$ & $\mathrm{mg} / \mathrm{L}$ \\
\hline 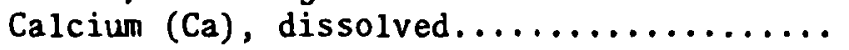 & 5 & .6 & $.1-1.3$ & $\mathrm{mg} / \mathrm{L}$ \\
\hline Magnesium $(\mathrm{Mg})$, dissolved............... & 5 & .2 & $.1-.4$ & $\mathrm{mg} / \mathrm{L}$ \\
\hline 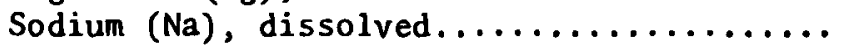 & 4 & 1.5 & $.9-2.4$ & $\mathrm{mg} / \mathrm{L}$ \\
\hline 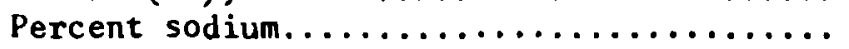 & 4 & 56 & $45-67$ & $\%$ \\
\hline Sodium-adsorption ratio................ & 4 & .4 & $.3-.5$ & 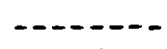 \\
\hline 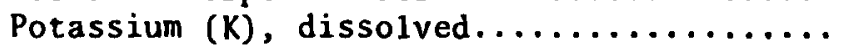 & 5 & .2 & $.1-.4$ & $\mathrm{mg} / \mathrm{L}$ \\
\hline Bicarbonate $\left(\mathrm{HCO}_{3}\right) \ldots \ldots \ldots \ldots \ldots \ldots$ & 11 & 5 & $3-8$ & $\mathrm{mg} / \mathrm{L}$ \\
\hline Carbon dioxide $\left(\mathrm{CO}_{2}\right) \ldots \ldots \ldots \ldots \ldots \ldots \ldots$ & 11 & 7 & $0-19$ & $\mathrm{mg} / \mathrm{L}$ \\
\hline Carbonate $\left(\mathrm{CO}_{3}\right) \ldots \ldots \ldots \ldots \ldots \ldots \ldots \ldots$ & 10 & 0 & 0 & $\mathrm{mg} / \mathrm{L}$ \\
\hline 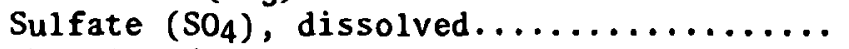 & 9 & 1.6 & $.7-2.9$ & $\mathrm{mg} / \mathrm{L}$ \\
\hline 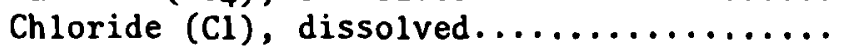 & 2 & 1.2 & $1.2-1.3$ & $\mathrm{mg} / \mathrm{L}$ \\
\hline Fluoride (F), dissolved.............. & 2 & .1 & $.0-.1$ & $\mathrm{mg} / \mathrm{L}$ \\
\hline Silica $\left(\mathrm{SiO}_{2}\right)$, dissolved.............. & 2 & 6.3 & $6.0-6.5$ & $\mathrm{mg} / \mathrm{L}$ \\
\hline Dissolved solids (sum of constituents)..... & 2 & 14 & $12-15$ & $\mathrm{mg} / \mathrm{L}$ \\
\hline Total nitrate $(N) \ldots \ldots \ldots \ldots \ldots \ldots \ldots$ & 2 & .01 & $.00-.01$ & $\mathrm{mg} / \mathrm{L}$ \\
\hline 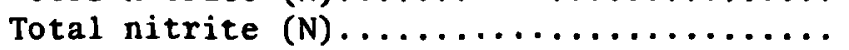 & 2 & .00 & .00 & $. \mathrm{mg} / \mathrm{L}$ \\
\hline Total Kjeldahl nitrogen $(N) \ldots \ldots \ldots \ldots \ldots$ & 2 & .20 & $.14-.27$ & $\mathrm{mg} / \mathrm{L}$ \\
\hline Total nitrogen $(\mathrm{N}) \ldots \ldots \ldots \ldots \ldots \ldots$ & 2 & .21 & $.14-.28$ & $\mathrm{mg} / \mathrm{L}$ \\
\hline Total nitrogen $\left(\mathrm{NO}_{3}\right) \ldots \ldots \ldots \ldots \ldots \ldots \ldots$ & 2 & .91 & $.62-1.2$ & $\mathrm{mg} / \mathrm{L}$ \\
\hline 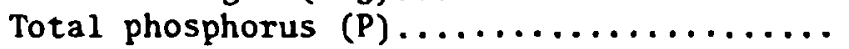 & 2 & .00 & .00 & $\mathrm{mg} / \mathrm{L}$ \\
\hline Total orthophorus phosphorus $(P) \ldots \ldots \ldots \ldots$ & 2 & .00 & .00 & $\mathrm{mg} / \mathrm{L}$ \\
\hline 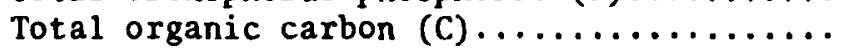 & 2 & 7.3 & $6.2-8.4$ & $\mathrm{mg} / \mathrm{L}$ \\
\hline Total inorganic carbon $(C) \ldots \ldots \ldots \ldots \ldots$ & 2 & 8.1 & $7.0-9.1$ & $\mathrm{mg} / \mathrm{L}$ \\
\hline 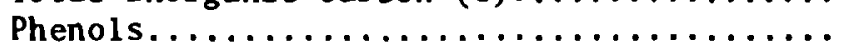 & 2 & 0 & 0 & $u g / L$ \\
\hline Alpha, gross dissolved as U natural....... & 4 & .4 & $.1-.7$ & $\mathrm{ug} / \mathrm{L}$ \\
\hline $\begin{array}{l}\text { Beta, gross dissolved as Cs }-137 \ldots \ldots \ldots \ldots \\
\text { Beta, gross dissolved as strontium/ }\end{array}$ & 2 & .9 & $.5-1.2$ & $\mathrm{PC} / \mathrm{L}$ \\
\hline 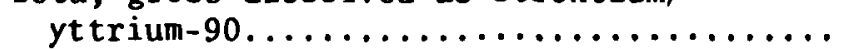 & 2 & .7 & $.4-1.0$ & $\mathrm{PC} / \mathrm{L}$ \\
\hline Radium-226, dissolved, Radon method........ & 2 & .08 & $.04-.1$ & $\mathrm{PC} / \mathrm{L}$ \\
\hline Uranium, natural dissolved (U) .......... & 1 & .0 & .0 & $\mathrm{ug} / \mathrm{L}$ \\
\hline
\end{tabular}

\begin{tabular}{|c|c|c|c|c|c|c|c|c|c|c|c|c|}
\hline \multirow[b]{2}{*}{ Property } & \multicolumn{4}{|c|}{ Dissolved } & \multicolumn{4}{|c|}{$\begin{array}{c}\text { Total recoverable in a } \\
\text { water-suspended sediment solution }\end{array}$} & \multicolumn{2}{|c|}{ Recoverable from } & \multicolumn{2}{|c|}{ bottom material } \\
\hline & $\begin{array}{c}\text { Number } \\
\text { of } \\
\text { analyses } \\
\end{array}$ & Mean & Range & Units & $\begin{array}{c}\text { Number } \\
\text { of } \\
\text { analyses }\end{array}$ & Mean & Range & Units & $\begin{array}{c}\text { Number } \\
\text { of } \\
\text { analyses }\end{array}$ & Mean & Range & Units \\
\hline Aluminum & 4 & 40 & $10-80$ & $u g / L$ & 1 & 30 & 30 & $u g / L$ & 2 & 100 & $10-230$ & $u g / g$ \\
\hline Arsenic & 2 & 1.0 & 1 & $\mathrm{ug} / \mathrm{L}$ & 1 & 1 & 1 & ug/L & 2 & 0 & 0 & $u g / g$ \\
\hline Boron & 2 & 20 & $0-40$ & ug/L & 1 & 0 & 0 & $\mathrm{ug} / \mathrm{L}$ & 2 & 0 & 0 & $\mathrm{ug} / \mathrm{g}$ \\
\hline Cadmium & 2 & 0 & 0 & $\mathrm{ug} / \mathrm{L}$ & 1 & 0 & 0 & $\mathrm{ug} / \mathrm{L}$ & 2 & $<10$ & $<10$ & $u g / g$ \\
\hline Chromium & 2 & 0 & 0 & ug/L & 1 & $<10$ & $<10$ & ug/L & 2 & $<10$ & $<10$ & $\mathrm{ug} / \mathrm{g}$ \\
\hline Cobalt & 2 & 0 & 0 & $u g / L$ & 1 & 0 & 0 & ug/L & 2 & $<10$ & $<10$ & ug/g \\
\hline Copper & 2 & 1 & $0-2$ & $\mathrm{ug} / \mathrm{L}$ & 1 & 10 & 10 & $\mathrm{ug} / \mathrm{L}$ & 2 & $<10$ & $<10$ & $\mathrm{ug} / \mathrm{g}$ \\
\hline Iron & 5 & 70 & $30-100$ & ug/L & 2 & 330 & $260-410$ & $\mathrm{ug} / \mathrm{L}$ & 2 & 520 & $300-750$ & $u g / g$ \\
\hline Lead & 2 & 6 & $0-13$ & $\mathrm{ug} / \mathrm{L}$ & 1 & 20 & 20 & $\mathrm{ug} / \mathrm{L}$ & 2 & $<10$ & $<10$ & $\mathrm{ug} / \mathrm{g}$ \\
\hline Lithium & 2 & 0 & 0 & $\mathrm{ug} / \mathrm{L}$ & 1 & 0 & 0 & ug/L & $-\ldots$ & --- & ------- & $\ldots$ \\
\hline Manganese & 4 & 15 & $10-20$ & $\mathrm{ug} / \mathrm{L}$ & 1 & 10 & 10 & ug/L & 2 & 30 & $20-40$ & ug/g \\
\hline Mercury & 2 & .0 & $.0-.1$ & $\mathrm{ug} / \mathrm{L}$ & 1 & 0 & 0 & ug/L & 2 & 0 & 0 & $u g / g$ \\
\hline Selenium & 2 & 0 & 0 & ug/L & 1 & 0 & 0 & $u g / L$ & 2 & 0 & 0 & ug/g \\
\hline Strontium & 2 & 40 & $30-40$ & $\mathrm{ug} / \mathrm{L}$ & 1 & 30 & 30 & $\mathrm{ug} / \mathrm{L}$ & 1 & 10 & 10 & $u g / g$ \\
\hline Zine & 2 & 20 & $10-20$ & $\mathrm{ug} / \mathrm{L}$ & 1 & 20 & 20 & $\mathrm{ug} / \mathrm{L}$ & 2 & 10 & $1-10$ & $\mathrm{ug} / \mathrm{g}$ \\
\hline
\end{tabular}

1/ Median value 
Table 14.--Summary of selected chemical and physical characteristics of water at site 7 (Yellow Creek near Northport)

\begin{tabular}{|c|c|c|c|c|}
\hline Property & $\begin{array}{c}\text { Number } \\
\text { of } \\
\text { analyses } \\
\end{array}$ & Mean & Range & Units \\
\hline Discharge. & 34 & 2.3 & $0.13-23$ & $\mathrm{~m}^{3} / \mathrm{s}$ \\
\hline Specific conductance (at $25^{\circ} \mathrm{C}$ )........... & 34 & 13 & $8-21$ & umhos $/ \mathrm{cm}$ \\
\hline 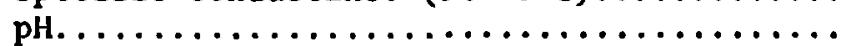 & 29 & $1 / 5.8$ & $4.6-6.8$ & units \\
\hline 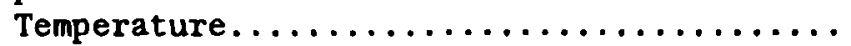 & 39 & -14.0 & $2.0-23.0$ & ${ }^{\circ} \mathrm{C}$ \\
\hline 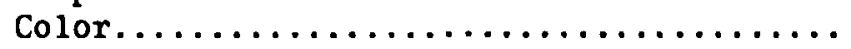 & 5 & 24 & $10-40$ & units \\
\hline Dissolved oxygen..................... & 13 & 9.7 & $7.8-13.8$ & $\mathrm{mg} / \mathrm{L}$ \\
\hline Hardness $\left(a s \mathrm{CaCO}_{3}\right) \ldots \ldots \ldots \ldots \ldots \ldots \ldots \ldots$ & 14 & 4 & $1-6$ & $\mathrm{mg} / \mathrm{L}$ \\
\hline Noncarbonate hardness $\ldots \ldots \ldots \ldots \ldots \ldots \ldots$ & 10 & 1 & $0-3$ & $\mathrm{mg} / \mathrm{L}$ \\
\hline Acidity as $\mathrm{H}^{+}, \ldots \ldots \ldots \ldots \ldots \ldots \ldots \ldots \ldots \ldots$ & 16 & .0 & $.0-.1$ & $\mathrm{mg} / \mathrm{L}$ \\
\hline Acidity as $\mathrm{CaCO}_{3} \ldots \ldots \ldots \ldots \ldots \ldots \ldots \ldots \ldots$ & 16 & .6 & $.0-5.0$ & $\mathrm{mg} / \mathrm{L}$ \\
\hline 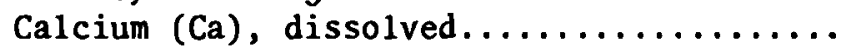 & 15 & 1.0 & $.4-1.6$ & $\mathrm{mg} / \mathrm{L}$ \\
\hline 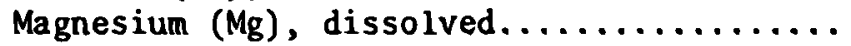 & 14 & .4 & $.1-.7$ & $\mathrm{mg} / \mathrm{L}$ \\
\hline 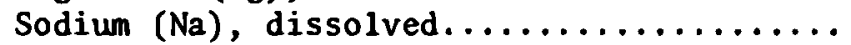 & 13 & 1.5 & $.7-5.2$ & $\mathrm{mg} / \mathrm{L}$ \\
\hline Percent sodium...................... & 13 & 37 & $0-67$ & $\%$ \\
\hline Sodium-adsorption ratio............... & 12 & .3 & $.1-1.0$ & $\ldots .$. \\
\hline 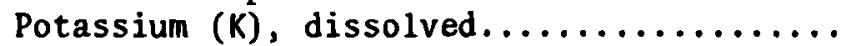 & 14 & .5 & $.1-.8$ & $\mathrm{mg} / \mathrm{L}$ \\
\hline Bicarbonate $\left(\mathrm{HCO}_{3}\right) \ldots \ldots \ldots \ldots \ldots \ldots \ldots \ldots$ & 24 & 4 & $2-10$ & $\mathrm{mg} / \mathrm{L}$ \\
\hline Carbon dioxide $\left(\mathrm{CO}_{2}\right), \ldots \ldots \ldots \ldots \ldots \ldots \ldots$ & 21 & 22 & $1.0-128$ & $\mathrm{mg} / \mathrm{L}$ \\
\hline Carbonate $\left(\mathrm{CO}_{3}\right) \ldots \ldots \ldots \ldots \ldots \ldots \ldots \ldots \ldots$ & 23 & 0 & 0 & $\mathrm{mg} / \mathrm{L}$ \\
\hline 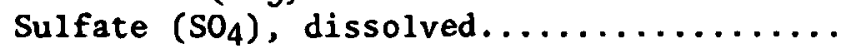 & 26 & 2.3 & $.7-4.1$ & $\mathrm{mg} / \mathrm{L}$ \\
\hline Chloride (C1), dissolved................ & $\mathbf{5}$ & 1.5 & $1.3-1.6$ & $\mathrm{mg} / \mathrm{L}$ \\
\hline 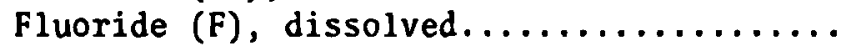 & 5 & .0 & .0 & $\mathrm{mg} / \mathrm{L}$ \\
\hline Silica $\left(\operatorname{Si0}_{2}\right)$, dissolved............... & 5 & 6.2 & $5.7-6.5$ & $\mathrm{mg} / \mathrm{L}$ \\
\hline Dissolved solids (sum of constituents)..... & 6 & 14 & $12-17$ & $\mathrm{mg} / \mathrm{L}$ \\
\hline Total nitrate $(N) \ldots \ldots \ldots \ldots \ldots \ldots \ldots \ldots$ & 5 & .02 & $.01-.03$ & $\mathrm{mg} / \mathrm{L}$ \\
\hline Total nitrite $(N) \ldots \ldots \ldots \ldots \ldots \ldots \ldots \ldots$ & 5 & .00 & .00 & $\mathrm{mg} / \mathrm{L}$ \\
\hline Total Kjeldah1 nitrogen (N) $\ldots \ldots \ldots \ldots \ldots \ldots$ & 5 & .14 & $.07-.22$ & $\mathrm{mg} / \mathrm{L}$ \\
\hline Total nitrogen $(\mathrm{N}) \ldots \ldots \ldots \ldots \ldots \ldots \ldots \ldots$ & 5 & .16 & $.10-.23$ & $\mathrm{mg} / \mathrm{L}$ \\
\hline Total nitrogen $\left(\mathrm{NO}_{3}\right) \ldots \ldots \ldots \ldots \ldots \ldots \ldots$ & 4 & .66 & $.44-1.0$ & $\mathrm{mg} / \mathrm{L}$ \\
\hline Total phosphorus $(\mathbb{P}) \ldots \ldots \ldots \ldots \ldots \ldots \ldots$ & 5 & .00 & $.00-.01$ & $\mathrm{mg} / \mathrm{L}$ \\
\hline Total orthophorus phosphorus (P) $\ldots \ldots \ldots \ldots$. & 5 & .00 & .00 & $\mathrm{mg} / \mathrm{L}$ \\
\hline Total organic carbon $(C) \ldots \ldots \ldots \ldots \ldots \ldots$ & 4 & 8.0 & $2.0-12$ & $\mathrm{mg} / \mathrm{L}$ \\
\hline Total inorganic carbon $(C) \ldots \ldots \ldots \ldots \ldots$ & 3 & 10 & $8.2-12$ & $\mathrm{mg} / \mathrm{L}$ \\
\hline Phenols........................... & 3 & 1 & $0-2$ & ug/L \\
\hline Alpha, gross dissolved as $U$ natural........ & 3 & .0 & .0 & $\mathrm{ug} / \mathrm{L}$ \\
\hline Beta, gross dissolved as Cs $-137 \ldots \ldots \ldots \ldots$ & 4 & .7 & $.4-1.1$ & PC/L \\
\hline Beta, gross dissolved as strontium/ & & & & \\
\hline 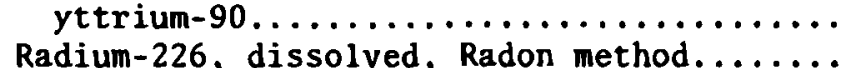 & 4 & .7 & $.5-.9$ & PC/L \\
\hline Radium-226, dissolved, Radon method. & 4 & .1 & $.05-.2$ & $\mathrm{PC} / \mathrm{L}$ \\
\hline Uranium, natural dissolved & 3 & .0 & .0 & $\mathrm{ug} / \mathrm{L}$ \\
\hline
\end{tabular}

\begin{tabular}{|c|c|c|c|c|c|c|c|c|c|c|c|c|}
\hline \multirow[b]{2}{*}{ Property } & \multicolumn{4}{|c|}{ Dissolved } & \multicolumn{4}{|c|}{$\begin{array}{l}\text { Total recoverable in a } \\
\text { water-suspended sediment solugion }\end{array}$} & \multicolumn{4}{|c|}{ Recoverable from bottom material } \\
\hline & $\begin{array}{c}\text { Number } \\
\text { of } \\
\text { analyses } \\
\end{array}$ & Mean & Range & Units & $\begin{array}{c}\text { Number } \\
\text { of } \\
\text { analyses } \\
\end{array}$ & Mean & Range & Units & $\begin{array}{c}\text { Number } \\
\text { of } \\
\text { analyses } \\
\end{array}$ & Mean & Range & Units \\
\hline Aluminum & 14 & 70 & $0-130$ & $u g / L$ & 11 & 900 & $80-1600$ & ug/L & 3 & 500 & $300-800$ & $u g / g$ \\
\hline Arsenic & 4 & 1 & $0-1$ & ug/L & 2 & 0 & 0 & ug/L & 3 & 1 & $0-1$ & $\mathrm{ug} / \mathrm{g}$ \\
\hline Boron & 3 & 10 & $0-30$ & $\mathrm{ug} / \mathrm{L}$ & 2 & 0 & 0 & ug/L & 3 & 0 & 0 & $\mathrm{ug} / \mathrm{g}$ \\
\hline Cadmiun & 4 & 1 & $0-1$ & ug/L & 3 & 10 & 10 & ug/L & 3 & $<10$ & $<10$ & $\mathrm{ug} / \mathrm{g}$ \\
\hline Chromium & 4 & 1 & $0-3$ & ug/L & 1 & 10 & 10 & ug/L & 1 & 30 & 30 & $\mathrm{ug} / \mathrm{g}$ \\
\hline Cobalt & 4 & 10 & 10 & $u g / L$ & 3 & 10 & 10 & $\mathrm{ug} / \mathrm{L}$ & 3 & $<10$ & $<10$ & $\mathrm{ug} / \mathrm{g}$ \\
\hline Copper & 4 & 1 & $0-2$ & ug/L & 3 & 10 & 10 & $\mathrm{ug} / \mathrm{L}$ & 3 & $<10$ & $<10$ & $\mathrm{ug} / \mathrm{g}$ \\
\hline Iron & 16 & 140 & $20-400$ & ug/L & 11 & 2400 & $260-5600$ & $\mathrm{ug} / \mathrm{L}$ & 3 & 1400 & $300-2000$ & $\mathrm{ug} / \mathrm{g}$ \\
\hline Lead & 4 & 3 & $0-4$ & $u g / L$ & 3 & 10 & 10 & ug/L & 1 & 40 & 40 & $\mathrm{ug} / \mathrm{g}$ \\
\hline Lithium & 4 & 0 & 0 & $\mathrm{ug} / \mathrm{L}$ & 3 & 0 & 0 & ug/L & $\ldots .$. & $\ldots$ & $\cdots+\cdots$ & $\ldots$ \\
\hline Manganese & 11 & 48 & $0-110$ & $\mathrm{ug} / \mathrm{L}$ & 10 & 98 & $10-190$ & $\mathrm{ug} / \mathrm{L}$ & 2 & 60 & $30-90$ & ug/g \\
\hline Mercury & 3 & .0 & $.0-.5$ & $\mathrm{ug} / \mathrm{L}$ & 1 & .5 & .5 & $\mathrm{ug} / \mathrm{L}$ & 3 & .1 & $.0-.2$ & $\mathrm{ug} / \mathrm{g}$ \\
\hline Seleniun & 4 & 0 & 0 & $\mathrm{ug} / \mathrm{L}$ & 2 & 0 & 0 & ug/L & 3 & 0 & 0 & $\mathrm{ug} / \mathrm{g}$ \\
\hline Strontium & 4 & 20 & $0-40$ & $\mathrm{ug} / \mathrm{L}$ & 3 & 10 & $0-30$ & ug/L & 1 & 10 & 10 & $\mathrm{ug} / \mathrm{g}$ \\
\hline Zinc & 4 & 10 & $0-10$ & $\mathrm{ug} / \mathrm{L}$ & 3 & 10 & $0-20$ & $\mathrm{ug} / \mathrm{L}$ & 2 & 10 & $5-10$ & $\mathrm{ug} / \mathrm{g}$ \\
\hline
\end{tabular}

1/ Median value 
Table 15.--Summary of annual suspended-sediment discharge and sediment yields at site 1 (Bear Creek near Samantha) and site 7 (Yellow Creek near Northport),

October 1976-September 1978

\begin{tabular}{|c|c|c|c|c|c|c|c|}
\hline \multirow[b]{2}{*}{$\begin{array}{c}\text { Site } \\
\text { number }\end{array}$} & \multicolumn{3}{|c|}{1977} & \multicolumn{3}{|c|}{1978} & \multirow[b]{2}{*}{$\begin{array}{l}\text { Mean } \\
\text { annual } \\
\text { sediment } \\
\text { yield } \\
\left(t / \mathrm{km}^{2}\right) \\
\end{array}$} \\
\hline & $\begin{array}{c}\text { Mean } \\
\text { stream } \\
\text { discharge } \\
\left(\mathrm{m}^{3} / \mathrm{s}\right) \\
\end{array}$ & $\begin{array}{l}\text { Annual suspended- } \\
\text { sediment discharge } \\
(t)\end{array}$ & $\begin{array}{c}\text { Annual } \\
\text { sediment } \\
\text { yield } \\
\left(\mathrm{t} / \mathrm{km}^{2}\right) \\
\end{array}$ & $\begin{array}{c}\text { Mean } \\
\text { stream } \\
\text { discharge } \\
\left(\mathrm{m}^{3} / \mathrm{s}\right)\end{array}$ & $\begin{array}{l}\text { Annual suspended- } \\
\text { sediment discharge } \\
(t)\end{array}$ & $\begin{array}{c}\text { Annual } \\
\text { sediment } \\
\text { yield } \\
\left(t / \mathrm{km}^{2}\right) \\
\end{array}$ & \\
\hline 1 & 0.65 & 4020 & 103 & 0.61 & 1780 & 46 & 75 \\
\hline 7 & 0.42 & 804 & 38 & 0.40 & 395 & 19 & 28 \\
\hline
\end{tabular}


Table 17.--Actual and relative numerical abundance of benthic invertebrates collected in riffles

( $C$ and $P$ denote Coker and Pottsville riffles, respectively)

\begin{tabular}{|c|c|c|c|c|c|c|c|c|c|}
\hline & $\begin{array}{l}\text { Total } \\
\text { numbers }\end{array}$ & $\begin{array}{l}\text { Percent } \\
\text { of total }\end{array}$ & $\frac{\text { Percer }}{\mathrm{C}}$ & $\frac{\text { int in }}{p}$ & & $\begin{array}{c}\text { Total } \\
\text { numbers }\end{array}$ & $\begin{array}{r}\text { Percent } \\
\text { of total }\end{array}$ & $\frac{\text { Percer }}{\mathrm{C}}$ & $\frac{\text { ent in }}{p}$ \\
\hline PLECOPTERA & 1600 & 23.74 & 88 & 12 & DIPTERA & 833 & 12.36 & 82 & 18 \\
\hline Perlodidae: & 11 & .16 & 0 & 100 & Tabanidae: & 66 & .98 & 88 & \\
\hline Ioogenus sp. & 11 & .16 & 0 & 100 & $\begin{array}{l}\text { Tabanioae: } \\
\text { Tabanus sp. }\end{array}$ & 66 & .98 & 88 & $\begin{array}{l}12 \\
12\end{array}$ \\
\hline Peltoperlidae: & 280 & 4.15 & 100 & 0 & Tipulidae: & 200 & 2.98 & 77 & 23 \\
\hline Peltoperla sp. & 280 & 4.15 & 100 & $\mathbf{0}$ & Hexatoma sp. & 51 & .76 & 94 & 6 \\
\hline $\begin{array}{l}\text { Perlidae: } \\
\text { Atoperla sp. }\end{array}$ & $\begin{array}{r}887 \\
3\end{array}$ & $\begin{array}{r}13.16 \\
.04\end{array}$ & $\begin{array}{r}87 \\
100\end{array}$ & $\begin{array}{r}13 \\
0\end{array}$ & Tpula sp. & 55 & .82 & 56 & 44 \\
\hline $\begin{array}{l}\text { Atoperla sp. } \\
\text { Perlesta sp. }\end{array}$ & $\begin{array}{r}3 \\
146\end{array}$ & 2.17 & 100 & 0 & $\begin{array}{l}\text { Antocha sp. } \\
\text { Dicranota sp. }\end{array}$ & 28 & .42 & 93 & 7 \\
\hline Acroneuria sp. & $\begin{array}{l}140 \\
673\end{array}$ & 9.99 & 83 & 17 & $\begin{array}{l}\text { Dicranota sp. } \\
\text { Poeudolimophila sp. }\end{array}$ & $\begin{array}{l}42 \\
24\end{array}$ & .62 & 100 & 0 \\
\hline Neoperla sp. & 65 & .96 & 100 & 0 & Simuliidae: & 133 & $\begin{array}{l}.36 \\
1.97\end{array}$ & $\begin{array}{l}33 \\
74\end{array}$ & $\begin{array}{l}67 \\
26\end{array}$ \\
\hline $\begin{array}{l}\text { Capnifidae: } \\
\text { AZlocapnia sp. }\end{array}$ & 345 & 5.12 & 92 & 8 & Prosimulium sp. & 7 & .10 & 0 & 100 \\
\hline $\begin{array}{l}\text { Nemouridae: } \\
\text { Noupnis sp. }\end{array}$ & 345 & 5.12 & 92 & 8 & Simulium sp. & 126 & 1.87 & 79 & 21 \\
\hline $\begin{array}{l}\text { Nemiridae: } \\
\text { Nemoura sp. }\end{array}$ & 24 & .36 & 8 & 92 & Rhagionidae: & 10 & .15 & 60 & 40 \\
\hline Taeniopterygidae: & $\begin{array}{l}24 \\
12\end{array}$ & .36 & 8 & 92 & Atherix variegata Walk. & 10 & .15 & 60 & 40 \\
\hline Taeniopteryx sp. & $\begin{array}{l}12 \\
12\end{array}$ & $\begin{array}{l}.18 \\
.18\end{array}$ & $\begin{array}{l}17 \\
17\end{array}$ & $\begin{array}{l}83 \\
83\end{array}$ & $\begin{array}{l}\text { Ceratopogonidae: } \\
\text { Porcipomyia sp. }\end{array}$ & $\begin{array}{r}34 \\
1\end{array}$ & $\begin{array}{l}.50 \\
.01\end{array}$ & $\begin{array}{r}94 \\
100\end{array}$ & 6 \\
\hline Chloroperlidae: & 41 & .61 & 63 & 37 & Atrichopogon sp. & 2 & .03 & $\begin{array}{r}100 \\
50\end{array}$ & $\begin{array}{r}0 \\
50\end{array}$ \\
\hline & 41 & .61 & 63 & 37 & Gonus $A$ & 31 & .46 & 97 & 3 \\
\hline COLEOPTERA & & & & & Emphidae: & 4 & .06 & 100 & 0 \\
\hline & 1254 & 18.61 & 77 & 23 & $\begin{array}{r}\text { Genus A } \\
\text { Ghi-n }\end{array}$ & 4 & .06 & 100 & 0 \\
\hline Psephenidae: & & & & & Chironomidae: & 387 & 5.72 & 85 & 15 \\
\hline Poephenus sp. & $\begin{array}{l}135 \\
133\end{array}$ & $\begin{array}{l}2.00 \\
1.97\end{array}$ & $\begin{array}{l}58 \\
59\end{array}$ & 42 & Conchapelopie sp. & 32 & .47 & 75 & 25 \\
\hline Eotopria sp. & 2 & .03 & $\begin{array}{r}59 \\
0\end{array}$ & $\begin{array}{r}41 \\
100\end{array}$ & Cricotopue sp. & 21 & .31 & 86 & 14 \\
\hline Hydrophilidae: & 1 & .01 & 100 & $\begin{array}{r}100 \\
0\end{array}$ & Dukiefferielia sp. & 32 & .47 & 72 & 28 \\
\hline Helocombus sp. & $i$ & .01 & 100 & 0 & $\begin{array}{l}\text { Paramstriocnemus sp. } \\
\text { Polypedilion sp. }\end{array}$ & 27 & .40 & 96 & 4 \\
\hline Elmidae: & 774 & 11.48 & 88 & 12 & $\begin{array}{l}\text { Polypedilion sp. } \\
\text { Rheotany tarous sp. }\end{array}$ & 129 & 1.93 & 91 & 9 \\
\hline Stenelmis sp. & 153 & 2.28 & 31 & 69 & & 15 & .22 & 80 & 20 \\
\hline $\begin{array}{l}\text { Conielmie distriohi } \\
\text { ontiosemus sp. }\end{array}$ & 3 & .04 & 100 & 0 & $\begin{array}{l}\text { Smittia sp. } \\
\text { Tanytareus sp. }\end{array}$ & $\begin{array}{r}8 \\
20\end{array}$ & $\begin{array}{l}.12 \\
.30\end{array}$ & $\begin{array}{r}100 \\
35\end{array}$ & $\begin{array}{r}0 \\
65\end{array}$ \\
\hline $\begin{array}{l}\text { Optiosemus sp. } \\
\text { oulimnius sp. }\end{array}$ & 218 & 3.23 & 98 & 2 & Thienemanniella sp. & 13 & .19 & 100 & 0 \\
\hline Macronychus glabratus & 395 & 5.86 & 99 & 1 & Trichocladius sp. & 7 & .10 & 71 & 29 \\
\hline Dubiraphic sp. & $\begin{array}{l}2 \\
3\end{array}$ & $\begin{array}{l}.03 \\
.04\end{array}$ & $\begin{array}{l}0 \\
0\end{array}$ & & Poectrocladius sp. & $\begin{array}{l}7 \\
5\end{array}$ & .10 & 86 & 14 \\
\hline Dryopidae: & 120 & $\begin{array}{l}.04 \\
1.78\end{array}$ & 8 & $\begin{array}{r}100 \\
92\end{array}$ & $\begin{array}{l}\text { Zaurelia sp. } \\
\text { Corynonsura sp. }\end{array}$ & $\begin{array}{l}5 \\
2\end{array}$ & $\begin{array}{l}.07 \\
.03\end{array}$ & 100 & 0 \\
\hline $\begin{array}{l}\text { Heliohus Sp. } \\
\text { Ptilotactilidae. }\end{array}$ & 120 & 1.78 & 8 & 92 & $\begin{array}{l}\text { Corynoneura sp. } \\
\text { Procladius sp. }\end{array}$ & 2 & $\begin{array}{l}.03 \\
.03\end{array}$ & $\begin{array}{l}50 \\
50\end{array}$ & 50 \\
\hline $\begin{array}{l}\text { Ptilodactilidae: } \\
\text { Anchytareue bicolor }\end{array}$ & 224 & 3.34 & 100 & 0 & Heterotrissociadius sp. & 8 & .12 & $\begin{array}{r}50 \\
100\end{array}$ & $\begin{array}{r}50 \\
0\end{array}$ \\
\hline Anchytareus bicolor & 224 & 3.34 & 100 & 0 & Phaenopaectra sp. & 4 & .06 & 100 & 0 \\
\hline EPHEMEROPTERA & & & & & Paracladopelma sp. & 4 & .06 & 100 & 0 \\
\hline & 2232 & 18.28 & 66 & 34 & $\begin{array}{l}\text { Xenochironomus sp. } \\
\text { Cardiocladius sp. }\end{array}$ & $\begin{array}{l}1 \\
2\end{array}$ & $\begin{array}{l}.01 \\
.03\end{array}$ & $\begin{array}{r}0 \\
100^{\circ}\end{array}$ & 200 \\
\hline Heptageniidse: & 727 & 10.79 & Bo & 20 & Orthocladius sp. & $i$ & .01 & $\begin{array}{l}100 \\
100\end{array}$ & 0 \\
\hline Epeorus sp. & 31 & .46 & 100 & 0 & Alabesmyia sp. & 2 & .03 & 50 & 50 \\
\hline $\begin{array}{l}\text { Stenonema sp. } \\
\text { Rhithroosna sD }\end{array}$ & 682 & 10.12 & 79 & 21 & Microtendipee sp. & 3 & .04 & 67 & 33 \\
\hline $\begin{array}{l}\text { Rhithrogena sp. } \\
\text { Ephemeridae: }\end{array}$ & 14 & .21 & 71 & 29 & Plecopteracoluthus sp. & 5 & .07 & 100 & 0 \\
\hline $\begin{array}{l}\text { Ephemeridae: } \\
\text { Hexagenia sp. }\end{array}$ & 1 & .01 & 100 & 0 & Sterochiromonus sp. & 2 & .03 & 100 & 0 \\
\hline Ephemerellidae: & 37 & $\begin{array}{l}.01 \\
.55\end{array}$ & $\begin{array}{r}100 \\
68\end{array}$ & $\begin{array}{r}0 \\
32\end{array}$ & Pentaneura sp. & 1 & .01 & 100 & 0 \\
\hline Ephemerella sp. & 37 & .55 & 68 & $\begin{array}{l}32 \\
32\end{array}$ & $\begin{array}{l}\text { Microopectra sp. } \\
\text { Chironomus sp. }\end{array}$ & 32 & .47 & 100 & 0 \\
\hline $\begin{array}{l}\text { Leptophlebiidae: } \\
\text { Habrophleboideo sp. }\end{array}$ & 75 & 1.11 & 59 & 41 & & 2 & .04 & 100 & 0 \\
\hline $\begin{array}{l}\text { Habrophleboides sp. } \\
\text { Caenidae: }\end{array}$ & 75 & 1.11 & 59 & 41 & MEGALOPTERA & 235 & 3.49 & 67 & 33 \\
\hline $\begin{array}{l}\text { Caenidae: } \\
\text { Caenio sp. }\end{array}$ & $\begin{array}{l}13 \\
13\end{array}$ & $\begin{array}{r}.19 \\
19\end{array}$ & 100 & 0 & & & & & \\
\hline Siphlonuridae: & 217 & $\begin{array}{r}.19 \\
1.74\end{array}$ & $\begin{array}{r}100 \\
3\end{array}$ & $\begin{array}{r}0 \\
97\end{array}$ & Corydalidae: & 205 & 3.04 & 62 & 38 \\
\hline Ieonyohia sp. & 117 & 1.74 & 3 & $\begin{array}{l}97 \\
97\end{array}$ & $\begin{array}{l}\text { Nigronia sp. } \\
\text { Corydalue sp. }\end{array}$ & $\begin{aligned} 128 \\
77\end{aligned}$ & 1.90 & 58 & 42 \\
\hline $\begin{array}{l}\text { Beetiscidee: } \\
\text { Baetioca so. }\end{array}$ & 1 & .01 & 0 & 100 & $\begin{array}{l}\text { Corydalue sp. } \\
\text { Sialidae: }\end{array}$ & $\begin{array}{l}77 \\
30\end{array}$ & $\begin{array}{r}1.14 \\
.45\end{array}$ & & $\begin{array}{r}30 \\
0\end{array}$ \\
\hline $\begin{array}{l}\text { Baetioca sp. } \\
\text { Baetidae: }\end{array}$ & $\begin{array}{r}1 \\
261\end{array}$ & $\begin{array}{r}.01 \\
3.88\end{array}$ & $\begin{array}{r}0 \\
55\end{array}$ & $\begin{array}{r}100 \\
45\end{array}$ & sialis sp. & 30 &. .45 & $\begin{array}{l}100 \\
100\end{array}$ & $\begin{array}{l}0 \\
0\end{array}$ \\
\hline Pseudocloeon sp. & 171 & $\begin{array}{l}3.88 \\
2.54\end{array}$ & 36 & $\begin{array}{l}45 \\
64\end{array}$ & ODONATA & 90 & & & \\
\hline $\begin{array}{l}\text { Baetio sp. } \\
\text { Genus A }\end{array}$ & 88 & 1.31 & 91 & 9 & & 90 & 1.33 & 33 & 67 \\
\hline & & .03 & 100 & 0 & Gomphidae: & 80 & 1.19 & 27 & 73 \\
\hline TRICHOPTERA & 1160 & 17.21 & 46 & 54 & $\begin{array}{l}\text { Dromogomphus sp. } \\
\text { Lanthue sp. }\end{array}$ & $\begin{array}{r}4 \\
76\end{array}$ & $\begin{array}{r}.06 \\
1.13\end{array}$ & $\begin{array}{r}100 \\
24\end{array}$ & $\begin{array}{r}0 \\
76\end{array}$ \\
\hline Hydropsychidae: & & & & & Cordulegastridae: & 3 & .04 & $\begin{array}{r}24 \\
100\end{array}$ & $\begin{array}{r}10 \\
0\end{array}$ \\
\hline Hydropoyohe sp. & $\begin{array}{r}874 \\
21\end{array}$ & 12.98 & 50 & 50 & Cordulegaster sp. & 3 & .04 & 100 & 0 \\
\hline Genus A & $\begin{array}{r}21 \\
1\end{array}$ & .32 & 100 & 0 & Aeshnidae: & 6 & .09 & 83 & 17 \\
\hline Diplectrone sp. & 36 & $\begin{array}{l}.01 \\
.53\end{array}$ & $\begin{array}{l}100 \\
100\end{array}$ & 0 & Boyeria sp. & 6 & .09 & 83 & 17 \\
\hline Cheumntopeyche sp. & 816 & 12.12 & 47 & 53 & $\begin{array}{l}\text { Coenagrionidae: } \\
\text { Genus }\end{array}$ & 1 & .01 & 0 & 100 \\
\hline Psychomyiidae: & 6 & .09 & 33 & 67 & Genus A & 1 & .01 & 0 & 100 \\
\hline $\begin{array}{l}\text { Polycen tropuo sp. } \\
\text { Genus A }\end{array}$ & $\begin{array}{l}5 \\
1\end{array}$ & $\begin{array}{l}.08 \\
.01\end{array}$ & $\begin{array}{r}40 \\
0\end{array}$ & $\begin{array}{r}60 \\
100\end{array}$ & HEMIPTERA & 23 & .34 & 43 & 57 \\
\hline Philopotamidae: & 205 & 3.04 & 11 & 89 & Veliidae: & 23 & .34 & 43 & \\
\hline Chimarra sp. & 202 & 3.00 & 10 & 90 & Rhagovelia sp. & 14 & .25 & 41 & 59 \\
\hline $\begin{array}{l}\text { Sortosa Sp. } \\
\text { Rhyacophilidae: }\end{array}$ & $\begin{array}{r}3 \\
24\end{array}$ & $\begin{array}{l}.04 \\
.36\end{array}$ & $\begin{array}{l}67 \\
75\end{array}$ & $\begin{array}{l}33 \\
25\end{array}$ & Microvelid sp. & 6 & .09 & so & 50 \\
\hline $\begin{array}{l}\text { Rhyacophila sp. } \\
\text { Gooridse: }\end{array}$ & 24 & .36 & 75 & 25 & CRASTACEA & 236 & 2.02 & 12 & 88 \\
\hline $\begin{array}{l}\text { Gooridae: } \\
\text { Goora sp. }\end{array}$ & 1 & $\begin{array}{l}.01 \\
.01\end{array}$ & $\begin{array}{l}100 \\
100\end{array}$ & $\begin{array}{l}0 \\
0\end{array}$ & Astacidae: & 17 & .25 & 88 & \\
\hline Brachycentridae: & 4 & .06 & 100 & 0 & $\begin{array}{l}\text { Astacidae: } \\
\text { Cembaruo sp. }\end{array}$ & 13 & .19 & 85 & 15 \\
\hline Micrasema sp. & 4 & .06 & 100 & 0 & Orconectes sp. & 4 & .06 & 100 & 0 \\
\hline $\begin{array}{l}\text { Hydroptilidae: } \\
\text { Aydroptila sp. }\end{array}$ & 20 & .30 & 90 & 10 & Asellidae: & 119 & 1.77 & 1 & 91 \\
\hline $\begin{array}{l}\text { Aydroptica sp. } \\
\text { Mayatrichic sp. }\end{array}$ & $\begin{array}{r}15 \\
5\end{array}$ & $\begin{array}{l}.22 \\
.08\end{array}$ & $\begin{array}{r}100 \\
60\end{array}$ & ${ }_{40}^{0}$ & Liroeus sp. & 119 & 1.77 & 1 & 99 \\
\hline $\begin{array}{l}\text { Lepidostomatidae: } \\
\text { Lepidostoma sp. }\end{array}$ & 3 & .04 & 33 & 67 & GASTROPODA & 28 & .42 & $\mathbf{0}$ & 100 \\
\hline Odontoceridae: & 12 & $\begin{array}{l}.04 \\
.18\end{array}$ & $\begin{array}{r}33 \\
100\end{array}$ & $\begin{array}{r}67 \\
0\end{array}$ & Planorbid & 7 & & & \\
\hline Poilotreta sp. & 12 & .18 & 100 & 0 & $\begin{array}{c}\text { Planorbidae: } \\
\text { Helizoma sp. }\end{array}$ & 7 & .10 & $\begin{array}{l}0 \\
0\end{array}$ & $\begin{array}{l}100 \\
100\end{array}$ \\
\hline $\begin{array}{l}\text { Leptoceridao: } \\
\text { Oecatio sp. }\end{array}$ & 3 & .04 & 100 & 0 & Pleuroceridae: & 21 & .32 & 0 & 100 \\
\hline $\begin{array}{l}\text { Oecetis sp. } \\
\text { Limnephilidae: }\end{array}$ & $\begin{array}{l}3 \\
2\end{array}$ & $\begin{array}{l}.04 \\
.03\end{array}$ & $\begin{array}{l}100 \\
100\end{array}$ & $\begin{array}{l}0 \\
0\end{array}$ & Pleurocera sp. & 21 & .32 & 0 & 100 \\
\hline $\begin{array}{l}\text { Neophylasx sp. } \\
\text { Glossosomatidae: }\end{array}$ & $\begin{array}{l}2 \\
1\end{array}$ & .03 & 100 & 0 & MISCELLANEOUS GROUPS & 149 & 2.20 & 55 & 45 \\
\hline Gloovosome sp. & i & .01 & $\begin{array}{l}100 \\
100\end{array}$ & $\begin{array}{l}0 \\
0\end{array}$ & & 3 & & & \\
\hline Helicopsychidae: & 5 & .07 & 100 & 0 & $\begin{array}{l}\text { Nematoda } \\
\text { Arachnoidea }\end{array}$ & 93 & $\begin{array}{l}.04 \\
1.37\end{array}$ & $\begin{array}{l}33 \\
45\end{array}$ & $\begin{array}{l}67 \\
55\end{array}$ \\
\hline Helicopoyche sp. & $\mathbf{5}$ & .07 & 100 & 0 & Oligochaeta & 51 & .76 & 75 & 25 \\
\hline & & & & & Platyhelminthes & 2 & .03 & 50 & 50 \\
\hline
\end{tabular}

61 
Achnanthaceae

Acanthes minutissima

A. stewartii *

A. Iinearis * f. curta

Cocconeis placentula v. Zineata

Nitzschiaceae:
Nitzchia denticula
N. dissipata
N. frustulum
N. clausii
N. palea
N. filiformis
Hantzschia amphioxys

Eunotiaceae :

\section{Eunotia carolina}

E. curvata

E. diodon *

E. flexuosa

E. flexuosa v. eurycephala

$E$. incisa

E. pectinalis

E. pectinalis v. minor

E. pectinalis v. ventricosa

E. rostellata

E. sudetica

E. vanheurckii v. intermedia

E. quaternaria

$E$. Iunaris $v$. subarcuata

E. bidentula

E. elegens

E. suecica

$E$. monodon

E. paralleza

$E$. serra v. diadema
E. pectinalis v. recta

Fragilariaceae:

Eragizaria constricta

$F$. vaucheriae

Tabellaria fenestrata

T. flocculosa

Meridion circulare

Synedra delicatissima

$S$. rumpens $v$. scotica

S. ulna

S. ulna $v$. oxyrhynchus f. mediocontracta

s. filiformis v. exilis *

Cymbellaceae:
Cymbella Lunata
C. tumida *
c. naviculiformes
C. minuta v. pseudogracilis
c. minuta
Amphora ovalis v. pediculus *

Gomphonemaceae :
Gomphonema angustatum
$G$. acumenatum
G. gracile
G. intricatum
G. purvulum
G. manubrium
G. truncatum v. capitatum
G. subclavatum v. commutatum

Surirellaceae:
Stenopterobia intermedia
Surirella ovalis
S. Zinearis
S. robusta v. splendida

Epithemiaceae:

Rhopalodia gibberula v. vanheurckii Denticala elegans *

Naviculaceae:

Anomoeoneis serians v. brachysira

A. vitrea

Caloneis ventricosa v. alpina

Frustulia rhomboides

F. rhomboides $v$. capitata *

$F$. rhomboides $v$. crassinervia

F. weenhoidii *

F. vulgaris

Navicula viridula $v$. avenacea

N. pupula v. elliptica

N. angusta

N. minuscula

N. secura

N. contenta $v$. biceps

N. hombergii

N. minima

N. notha

N. pupula v. elliptica

$N$. pupula v. rectangularis

$N$. radiosa v. parva

Stauroneis livingstonii

S. obtusa

S. phoenicenteron f. gracilis

S. fluminea

$S$. anceps $f$. gracilis

S. kreigeri

s. smithii *

Neidiwn affine v. Zongiceps

N. affine

N. apiculatum

N. iridis v. ampliatum

$N$. dubium f. constrictum

Pinnularia borealis

P. acrosphaeria *

P. abaujensis

P. biceps

$P$. biceps f. petersenii

P. divergens v. elliplica

P. braunii v. amphicephala

P. subcapitata

$P$. termitina

P. mesogongyla

P. formica

P. socialis

$P$. rupestris

Amphipleura pellucida *

Diploneis puella *

D. oculata * 


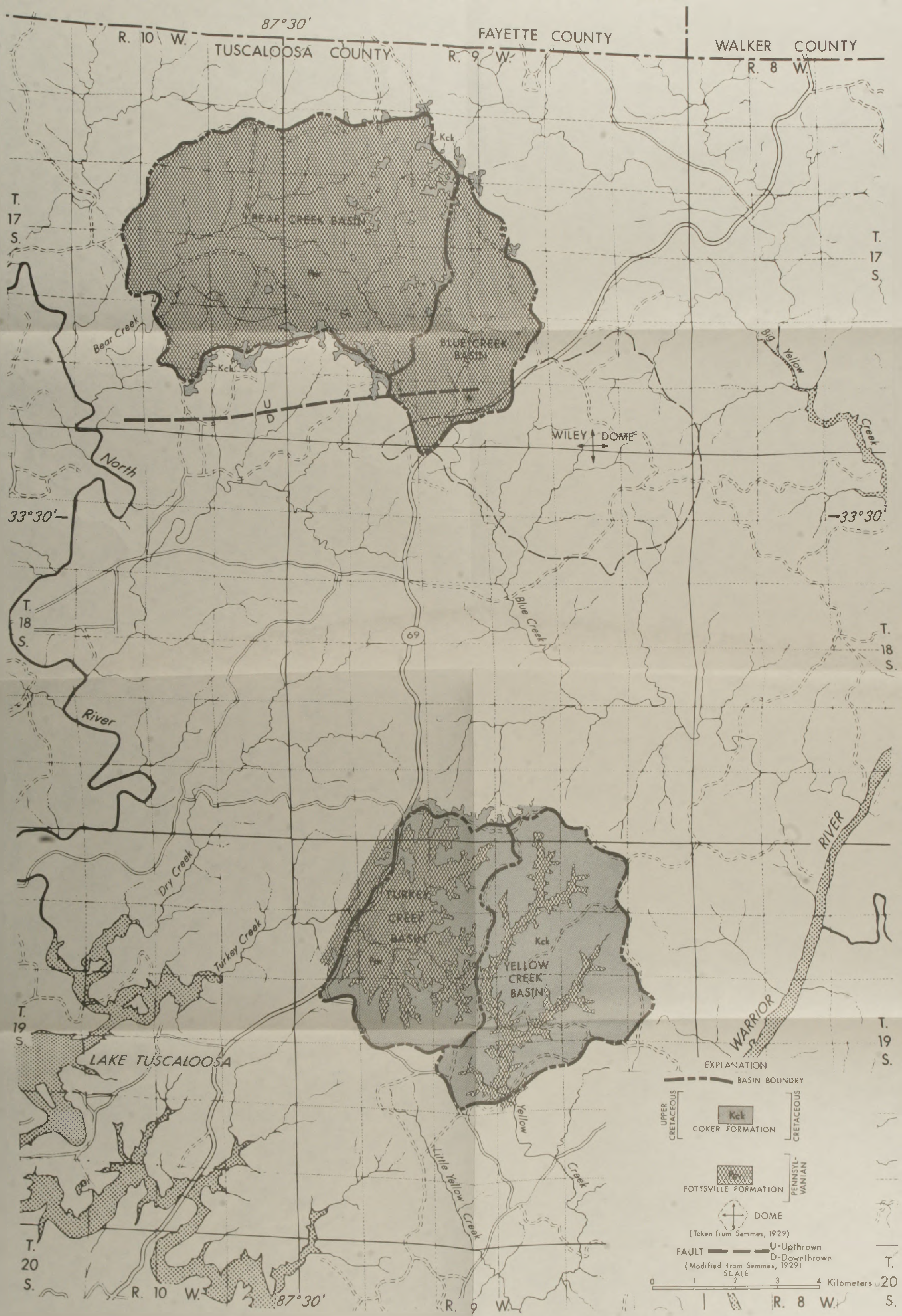

Plate 1. Geologic map of areas of study. 


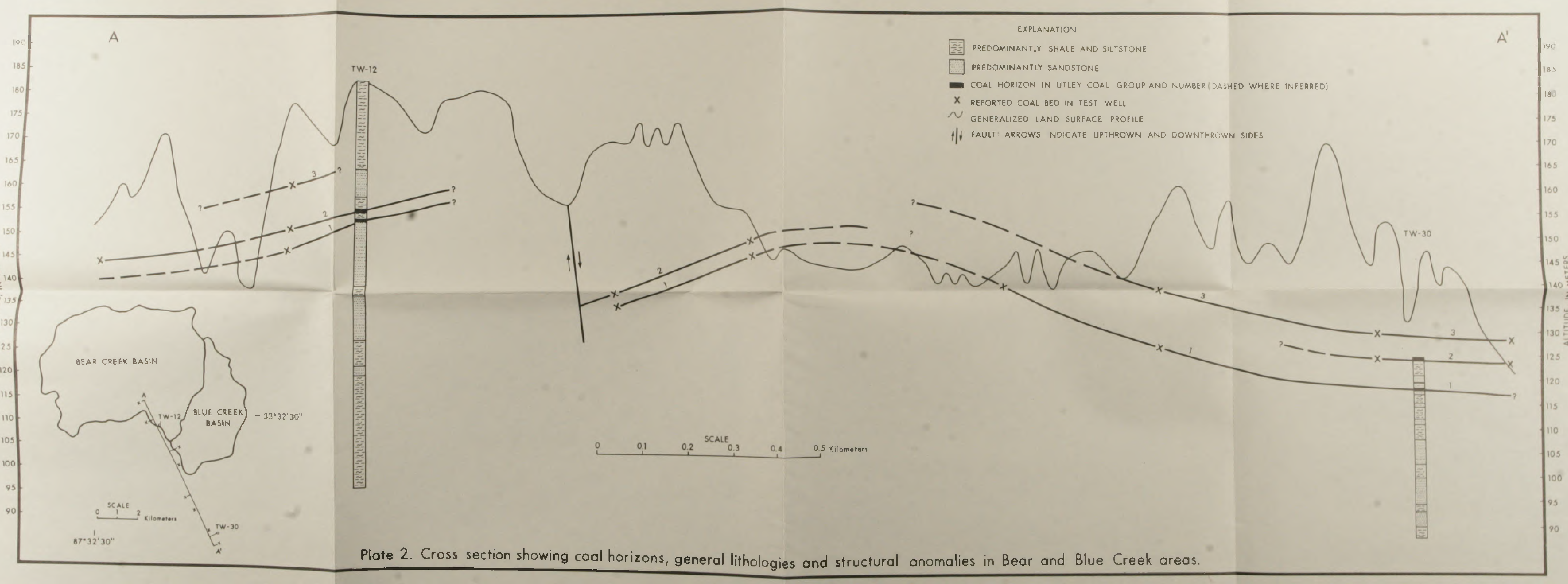




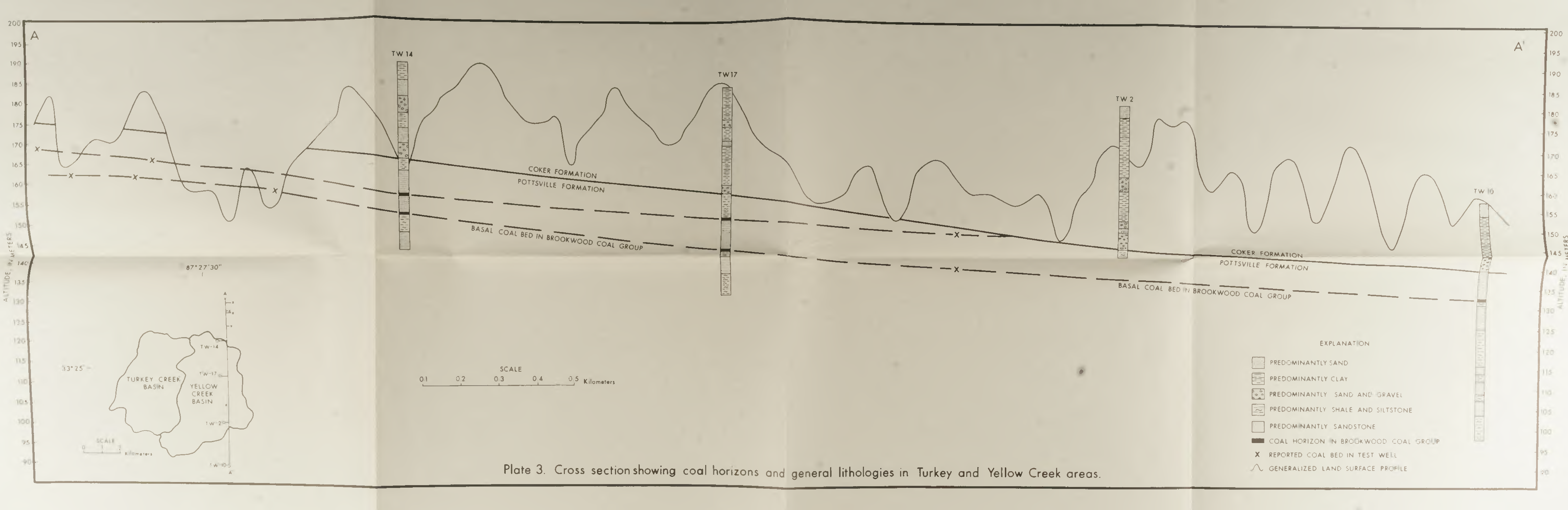


